\title{
Diagnostic procedures in breast cancer
}

Citation for published version (APA):

Bosch, A. M. (2005). Diagnostic procedures in breast cancer. [Doctoral Thesis, Maastricht University]. Universitaire Pers Maastricht. https://doi.org/10.26481/dis.20050921ab

Document status and date:

Published: 01/01/2005

DOI:

10.26481/dis.20050921ab

Document Version:

Publisher's PDF, also known as Version of record

\section{Please check the document version of this publication:}

- A submitted manuscript is the version of the article upon submission and before peer-review. There can be important differences between the submitted version and the official published version of record.

People interested in the research are advised to contact the author for the final version of the publication, or visit the DOI to the publisher's website.

- The final author version and the galley proof are versions of the publication after peer review.

- The final published version features the final layout of the paper including the volume, issue and page numbers.

Link to publication

\footnotetext{
General rights rights.

- You may freely distribute the URL identifying the publication in the public portal. please follow below link for the End User Agreement:

www.umlib.nl/taverne-license

Take down policy

If you believe that this document breaches copyright please contact us at:

repository@maastrichtuniversity.nl

providing details and we will investigate your claim.
}

Copyright and moral rights for the publications made accessible in the public portal are retained by the authors and/or other copyright owners and it is a condition of accessing publications that users recognise and abide by the legal requirements associated with these

- Users may download and print one copy of any publication from the public portal for the purpose of private study or research.

- You may not further distribute the material or use it for any profit-making activity or commercial gain

If the publication is distributed under the terms of Article $25 \mathrm{fa}$ of the Dutch Copyright Act, indicated by the "Taverne" license above, 
Diagnostic procedures in breast cancer - with a summary in Dutch 
$1 \mathrm{SBN} 9052784779$

Copyright 0 Mastricht 2005. All rights teserved

The work presented in this thesis was financially supported by a grant from the Dutch Health Care Insurance Executive Board

The ultrasonographic examinations were possible by making available the HDI 5000 by A II $]_{-,}$Bothell-Washington

The publication of this thesis was financially supported by Hunkemöller BV and GlaxoSmithKline Lay-out: 1. Kengen Novartis Pharma BV and AstraZeneca BV

Printed by: Datawyse 


\title{
Diagnostic procedures in breast cancer
}

\author{
Proefschrift
}

ter vetkrijging ran de graad van doctor aan de Universiteit Maastricht, op gezag van de Rector Magnificus, Prof. dr. G.P.M.F. Mols, volgens het besluit van het College van Decanen, in het openbaar te verdedigen op woensdag 21 september $2005 \mathrm{om} 12.00$ uur.

door

Anna Maria Bosch

geboten op 14 januari 1970 te PANNERDEN (GLD)

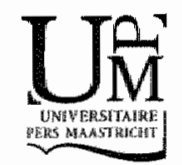




\section{Promotores}

Prof. dr. M.F. von Meyenfeldt

Prof dr. J.M.A. van Engelshowen

\section{Copromotor}

Dr. G.I. Beets

\section{Beoordelingscommissie}

Prof. dr. H.C. Schouten (voorzitter)

Dr. A.P. de Bruine

Prof. dr. Ph. Lambin

Dr. E.J.Th. Rutgers (Nederlands Kanker Instituut/Antoni van Leeuwenhoek ziekenhuis, Amsterdam) 


\section{TABLE OF CONTENTS}

Chapter I GENERAL INTRODUCTION

CHAPTER II A NEEDLE-LOCALISED OPEN-BREAST BIOPSY FOR NONPALPABLE BREAST LESIONS SHOULD NOT BE PERFORMED FOR DUGNOSIS

CHAPTER III PRE-OPERATIVE ESTMATION OF THE PAHTOLOGICAL BREAST TUMOUR SIZE BY PHYSICAL FXAMNATION, MAMMOGRAPHY AND ULTRASOUND: a prospective study on 105 invasive tumours

CHAPTER IV PREDICTIVE DIAGNOSTIC VARIABLES IN THE DIAGNOSTS OF BREAST CANCER: the role of whole breast ultrasonography as adjunce to mammography and physical examination

CHAPTER V INTEREXAMINATION VARIATION OF WHOLE BREAST ULTRASOUND

CHAPTER VI ADDTTIONAL PRE-OPERATVE ADDTTIONAL DIAGNOSTIC ANALYSIS FOR A PALPABLE BREAST LESION: the role of the triple diagnostic test and the histological core needile biopsy

CHAPTER VII HISTOLOGICAL CORE NEEDLE BIOPSY OF PALPAHLE BREAST 1.ESIONS: inage or palpation-guided?

ChAPTER VIII GENERAL DISCUSSION AND CONCLUSIONS

Chapter IX Summary 



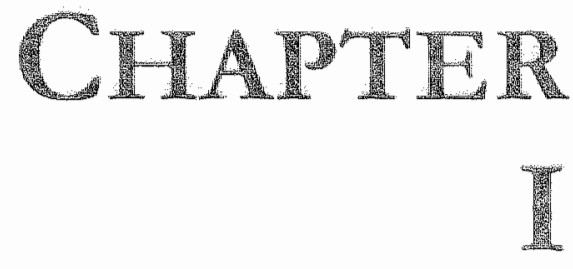

General introduction 
Breast discase has been documented back to the early Egyptians (1600 BO).1, 2 Nowadays breast cancet is one of the leading causes of cancer morbidity and mottality among women. Of the 60,000 new cancers that are diagnosed each year in the Netherlands, about 11,200 are breast cancers ${ }^{3,4}$ and approximately one in every nine women will get bteast catucet at some point in her life. The discovery of a lump in the breast has a strong emotional impact on a woman's well being. In addition to the life-threatening consequences of breast cancer itself, the fear of mutilating surgical procedures and a period of uncertainty cause much distress.

For general practitioners and specialists it is essential to differentiate benign breast disease from breast cancer. Since only a small amount of breast lesions are malignant $\left(9-11 \% 0^{3}\right)$, the diagnostic work-up of these patients must have a high sensitivity and specificity to prevent diseased patients from being sent home with the false reassurance that nothing is wrong (false-negative tesults) and to prevent healthy patients from undergoing further unnecessary diagnostic and therapeutic procedures (false-positive results). In daily dinical practice early diagnosis, which indicates smaller lesions, improves the prognosis of the patient. ${ }^{6-10}$ Since the introduction of the national breast-screening programme in the Netherlands in the early $1990 \mathrm{~s}$ mote small, non-palpable lesions have been detected, which have needed further analysis. Specific qualities were asked from these further diagnostic procedures.

Since the mid-1990s diagnostic guidelines on breast cancer screening and diagnostics have been pulblished in medical joumals and by national wotking groups and groups from their own institution, for example: British Association of Surgical Oncology (BASO)", European Sociery of Surgical. Oncology (ESSO) ${ }^{12}$, National Health Service Breast Screening Programme; Surgical Co-ordination Group for Breast Cancer Screening (NHSBSP) ${ }^{13}$. Internationally these guidelines have been further developed (EUSOMA). ${ }^{14}$ In the Netherlands guidelines are published by a working group partly under the auspices of the Dutch Institute for Health Care Improvement (Dutch acronym: CBO), the Organisation of Comprehensive Cancer Centres (Dutch acronym: VvIKC) and the National Breast Group of the Nethetlands (Dutch acronym: NABON) ${ }^{15}$. This working group has formulated recommendations including instructions for diagnosis outside the Durch population-screening progtamme, and for diagnostic procedures of symptomatic and asymptomatic lesions in the breast. They have also made a recommendation for the percentage of lesions that have to be diagnosed prior to surgical excision (70-90\%).

Surgical breast biopsy, and, for non-palpable lesions, needle-localised breast biopsy, have been the reference tests for the diagnosis of breast disease. In cases where a surgical biopsy is meant as a diagnostic procedure, the first goal is not a radical excision with wide tumour-free margins. As a consequence different authors have found a substantial proportion of cases, ranging from $56 \%$ to $65 \%$, with unsatisfactory margins among patients with non-palpable lesions in whom a diagnostic needle-localised excision is performed ${ }^{16,17}$. We know from the literature that residual invasive breast carcinoma has a higher incidence of local recurrence and requires further and more aggressive surgery 18.25 . 
PRE OPERATTVE DLAGNOSTS OF BRE ATT DTEA ASE

Following history taking, physical examination is the first diagnostic modality to find and describe a breast lesion. Its sensitivity and specificity to distinguish certainly benign from certainly malignant is low 26 . For a breast lesion to become palpable depends on the density of the surtounding tissue, the size of the breast, the site in the breast, the experience of the physician, etc. Generally, a tumour size of over $10 \mathrm{~mm}$ should be palpable. The smaller the breast cancer, the better the prognosis and the less palpable the lesion.

Following history taking and physical examination by a general practitioner or specialist, a woman with breast complaints or a high risk of breast cancer is referred to the radiology deparment for diagnostic breast imaging. The first report on roentgenography of the breast appeared in the beginning of the $20^{\text {th }}$ century. Mammography, using dedicated equipment and procedures, was introduced for general practice in the $1960 \mathrm{~s}^{27}, 2.3$. Vartous other imaging modalities have been developed and optimised for their use in breast diagnostics, of which ultrasonography has become the most relevant and readily available non-invasive adjunct to mammography 20.31 . Already in the 1950 s ultrasonography was occasionally used to image breast rissue $32,3.3$ and nowadays this technique is routinely used to differentiate solid from cystic masses seen on mammography or found by palparion and for image-guided biopsy. When a palpable mass is not visible or when the density of the breast tissue obscures the lesion on a mammogram, ultrasonogxaphy is used to detect and describe the mass ${ }^{34}$.

Definitive diagnosis is made through tissue examination. Fine needle aspiration cytology makes it possible to obtain individual cells or small groups of cells from a tumour for assessment by a parhologist. "This procedure was added to the physical examination and imaging to lead to an accurate diagnosis in the so-called triple diagnostic test, and was initially described in the mid $1970 \mathrm{~s}, 35,36$ Sensirivity rates of the fine needle aspiration cytology in diagnosing breast cancer vary between $44 \%$ and $92 \%$, with most of the variation clue to different calculation methods. This makes comparison of studies difficult. The combination of physical examination, imaging and fine needle aspitation cytology has a false-negative rate of $0.35 \%$ and a non-concondant rate up to $48 \% 0^{37.3 \%}$. Triple diagnostic test results which still do not yicld an either certainly benign of cerainly malignant judgement are therefore tather common: up to $54 \%, 40$ Another drawback of fine needle aspiration cytology is the inability to differentiate between catcinoma in situ and invasive catcinoma.

To deal with the incompleteness of the triple diagnostic test procedure, and to obrain a histological diagnosis prior to surgery, Roberts introduced the histological core needle biopsy of the breast in the 1970s." This diagnostic modality is now widely used for histological examination of a breast lesion. ${ }^{42}{ }^{43}$ It provides an actual histological sample on which a pathologist is able to establish the presence of invasive disease, to assess the rumour grade and the hormone receptor starus. If the lesion is found, in concordance with the other diagnostic procedures, to be benign, no further surgery is necessaty, while if malignancy is demonstrated the definitive therapeutic intervention can be planned and discussed with the patient before the operation. 
The aim of this thesis is to evaluate the pre-operative diagnostic methods of a breast lesion, in an atrempt to further improve performance in daily clinical practice. For this purpose warious aspects of the pre-operative diagnostic ronte are elucidated, with a special interest in the ultrasonography of the breasts. The studies were executed with populations from the Maastricht Unwersity Hospital. This is a 700-bed referral hospical with an important regional function for the south of the Netherlands. The number of breast imaging procedures in this hospital has been increasing. For example, ultrasonography as adjunct to mammography increased from $28 \%$ of all patients referred for breast imaging in 1994 to over $35 \%$ in 1999 .

The retrospective study in chapter II is a plea for optimising the pre-operative diagnostic procedure to yield optimal treatment of breast lesions. The purpose of the study was to determine pre-operative factors that influence the probability of obtaining tumourfree margins after a needle localised excision of a non-palpable breast carcinoma.

As breast tumour size is a major prognostic indicator and has impact on staging and choice of treatment strategy chapter III determines the best diagnostic modality for a preoperative estimation of a breast tumour size. In this study we compare the results of tumour size determination by physical examination, mammography and ultrasonography with the histological tumour size.

A systematic literature review about ultrasonography of the breast as an adjunct to mammography in clinical practice showed little evidence-based support ${ }^{45}$. Chapter IV reports on the results of a large prospective cohort study on breast ultrasonography (the MAMMOED-study; MAMmacarcinoom-studie Maastricht: Optimalisatie Echografische Djagnostiek). This study was performed at Maastricht University Hospital between October 1, 1999 and August 1, 2000. It tests in a non-screening outpatient population the additional diagnostic value of ultrasonography as an adjunct to mammography and physical examination in the diagnosis of breast cancer and identifies subgroups of patients (according to the reason for referral for breast imaging and age) in which the highest diagnostic yield would be obtained. The power analysis for this study showed the need of 90 patients with breast cancer. With an estimated incidence of breast cancer around $4.5 \%$ in such a population, 2000 patients were required for this study (at a confidence interval of $95 \%$. In a 10 -month period 3835 breasts were examined in 2020 patients.

Ulmasonography is known to be an operator dependent examination. Chapter $V$ describes the interexamination variability of the utrasound examination of the whole breast tising Kappa statistics.

In chapter VI the diagnostic performance of the triple diagnostic test is evaluated and the additional value of the histological core needle biopsy in the patients with a suspicious palpable breast lesion is determined. Additionally it was examined whether the necessiry of such a biopsy could be predicted on the basis of patient or image oriented patameters.

Because the histological core needle biopsy is a useful addirional pre-operative diagnostic modality in diagnosing a breast lesion, we describe in chapter VII the diagnostic performance of the histological core needle biopsy of palpable breast lesions obtained by image guidance (stereotactic or ultrasonographic) or by palpation guidance.

Finally chapters VIII and IX summarise, discuss and indicate the clinical impact of the most important findings presented in this thesis. 


\section{REFERENCES}

1. Brewsted, J.H., The Edwin Snith Surgical Papynas. 1930 : Chicago. p. 207.

2. Robinson, J.O., Treatment of Breat Cancer Whough the Ages. Am J Surg, 1986. 151:317.3.

3. VIKC, Incidence of cancer in the Netherlands $1909 / 2000$, Eleventh toport of the Netherlands Cuncer Registy. 2003, [Vereniging wan Integrale Kantercentra], Association of Comprehensive Cance Centres: Uredut. 15-20.

4. KWT Kankerbestriding. Kanker in Nederkand. Trends, prognoses en implicaties woor zotgrang. 2004. Signaleningscommissie Kanker van KWF Katrketbestrijding. Eindhowen. p. 123.

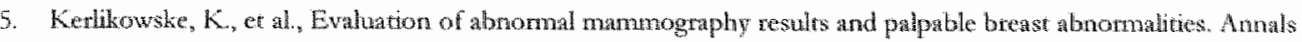
of Internal Medicine $2003.139(4): 27485$

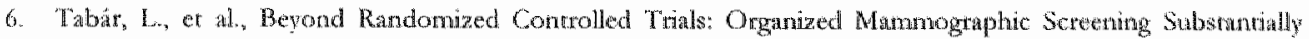
Reduces Breast Carcinoma Mortality. Cancer, 2001. 919y: 1724-31.

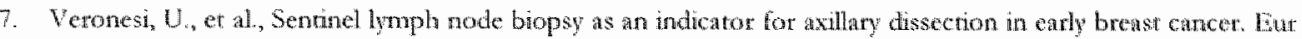
J Cancer, 2001. $37(4): 454-8$.

8. Cowen, D. et al, Local and distant recumence afrer consevative managemen of very low-risk breast cancer are dependent exents; 10-year tollow-up. Int J Radiar Oncol Biol Phys, 1998. 41(4): 801 \%.

9. Dongen war, J.A., et al, Factors influencing local relapse and survial and results of salvage treattuent after breast-conserwing thempy in operable breast cances. FORTC trial 10801, breast conseration compured wilh mastectomy in TWM stage I and II breast cancer. Eur ] Cance, 1992. 28A (4-5): 801-5.

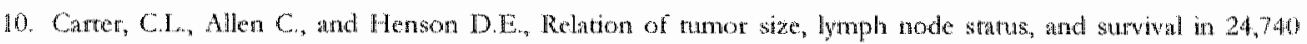
breast cancet cases Cancer, 1989.63(1):181-7.

11. Blatney, R.W., The British Association of Surgical Oncology Guidelines for surgeons in the management of symptomatic breast disease in the UK (1998 revision). BASO Breast Specialng Coroup. Eur I Surg Oncol 1908. 24(6): 46476.

12. Blickert-Toft, M., et al., Principles and guidelines for surgeons in the managenent of symptomatic breats cancer. Eur] Surg Oncol, 1997. 23:101-9.

13. NHSBSP, Quality assurane guidelines for sugeons in breast disedse. 1992, NHSBSP publications: Shetfield.

14. Pery, N.M. on behalf ot the EUSOMA Working Party, Quality assurance in the diagnosis of breast disease Eur 1Cancer, $2004.37: 159-72$.

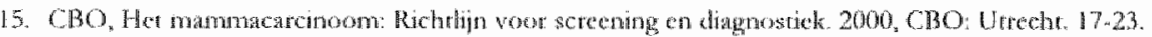

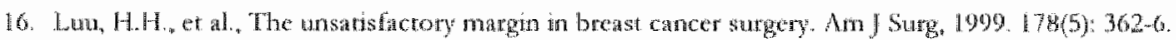

17. Besic, N., et al. Brost biopsy wht wire localization: factors influcheing complete exciton of nompalpable carcinoma Eur Radiol, $2002,12(1)$ : 2684-\%.

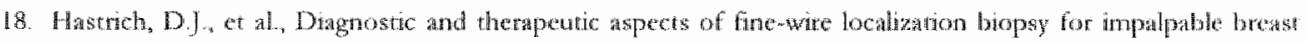
cancer. Br J Surger. 1992. 79(10): 1038-41.

19. Sprwack. B. et al, Margin status and local trecurence after breast conserving sugery. Arth Surg, 1994, 129)(9): $952-6$, discussion $056-7$

20. Schnit, S. ., er al, The relationship between microscopic matgins of resecton and the risk of local recumence in

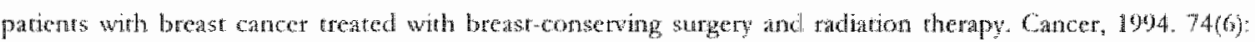
$1746-51$.

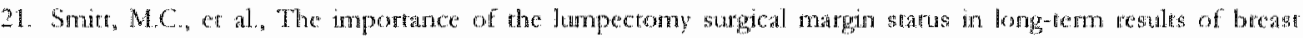
conservation, Cancer, 1995. 70(2): $259-67$.

22. Ym, J.H, et al, Mammographicallyy derected breast cancet. Benefirs of steretactic cone wersus wire localizanion biopsy. Ann Surg, $1996.223(6): 688.97$; discussion 697.700. 
23. Diblase, S.I, et al, The number of powive margins influences the ontcotre of women treated with breast preserwation for enty stage brease carcinoma Cancer, 1998.8241 \% $2212-20$

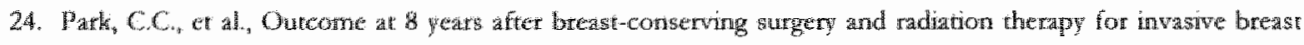

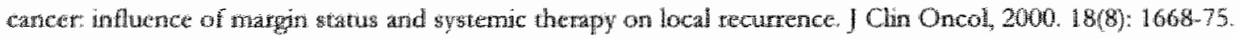

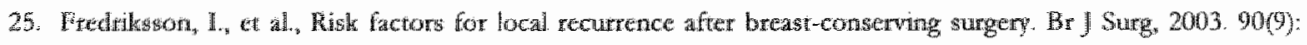
$1093-102$

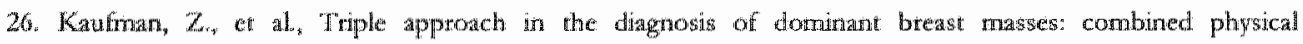
examination, mamumography, and fine nedle aspiration. J Surg Oncol, 1994. 56(4):2547.

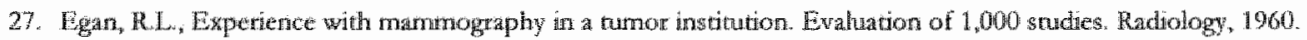
75: 89.900.

28. Gtos, C., [Breagr adiolopy]. I Radiol Electrol Med Nucl, 1975. 56 suppl 1:311.

29. Skaane, P., Olersomoggraphy as adjunet to mammography in the ewaluation of breast tumors. Acta Radiol Suppl. 1999. $420: 1-47$.

30. Jackson, V.P, Reynolds H.E, and Hawes D.R, Sonography of the breast Semin Uleraund CT MR, 1996. $17(5): 40075$

31. Mendeson, E. B. and Tobin C. E, Critical pathways in wing breast US. Radiogrtaphics, 1995. 1544):935-45.

32. Wild, Js. and Reid J.M., Further pilot echographic staches on the histologic structure of tumors of the living intact human breast, Am ll Pathol, 1952. 28(5): 839-61.

33. Nowny, D.H., Stot D.A, and Blis, W.R., "The ultrasonic visualization of carcinoma of the breast and other softdistue structures. Cancer, 1954, 7(2): 3548.

34. Leconte, 1., er all. Mammography and subsequent whole-breast sonography of nonpalpable breast cancers: The importance of radiologic breast densicy. An \ Roenigenol, 2003. 180: $1675-9$.

35. Johansen, $C$, A clinical study with special reference to diagnostic procedures Acta Clin Scand, 1975. 451/supply: $1,-70$.

36. O'Neil, S, er al, Fine needle aspiration of 697 palpable breast lesions with histopathologic correlation. Surgery, 1997. $122(4): 8248$.

37. Clamke, D., Sudhakaran N., and Gateley C.A., Replace fine needle aspiration cytology with automated core biopsy in the triple assessment of breast cancer. Ann R Coll Surg Engl, 2001. 83(2): 110.2.

38. Vetro, $J_{\text {., }}$ et al, Use of the "triple test" for palpable breast lesions yields high diagnostic accuracy and cost sinving Am J Surg, 1995. 169)(5): 51922.

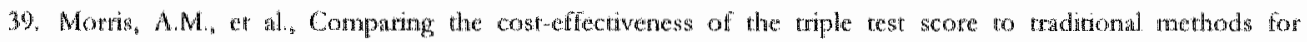

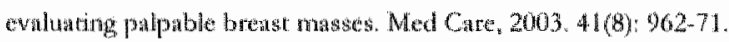

40. Wells, C.A., Quality awsurance in breast cancer screening cytology: a review of the liferature and a report on the U.K. maticnal cytology scheme. Lur J Cancer, 1995 . $31 \mathrm{~A}(2): 273.80$.

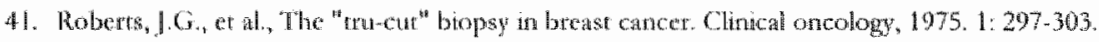

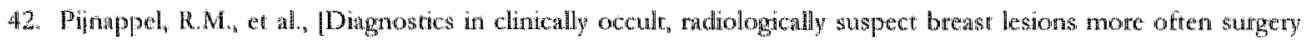
than needle diagnostics with imange monitoringl. Ned Tijdsclu Geneeskd, 2001. 145(14): 691-4.

43. Liberman, L., Percutaneous Imaging Guided Core Breast Biopsy: State of the Art at the Malennitum. Am I Roentgenol, 2000, 174(May): 1191.9.

44. Flobbe, K, et al "Diagnostic walne of radiological breast imaging in a non-screening population. Int ] Cancer, 2001. $92(4): 616-8$

45. Mobbe, $\mathbb{K}$, al. "The role of ultasonography as adjunct to mammography whe detection of breast cancer a systenic review. Eur. ] Cancer, 2002 38: 1044-50. 


\section{CHAPTER}

II

\section{A needle-localised open-breast biopsy for non- palpable breast lesions should not be performed for diagnosis}

A.M. Wrasch

Ci.l. Bects

A.G.H. Kussels

J.M.A. wan Engelshowern

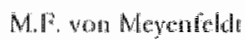

The Btents. 2004; 13(6):476-482 
ABSTRACT - The achievement of tumour-free margins on excision of non-palpable breast lesions that have aroused only an internediate or low level of suspicion before surgery and do turn out to be malignant is a challenge for the surgeon. The purpose of this study was to determine factors that influence the probability of obtaining tumour-free margins after needle-localised excision of a non-palpable breast carcinoma. Methods During a 10-year period all needle-localised breast biopsies (NLBB) carried out in the Department of Surgery were retrospectively analysed. Possible influential factors considered included: age of the patient, year of NLBB, appearance of the lesion on imaging, pre-operative diagnostic index, method of localisation, surgeon's level of experience, specimen size and tadiology of the specimen, and all these were analysed in a multivariate logistic regression analysis. Results - In all, 400 needle-localised breast biopsies had been pefformed. Excision with tumour-free margins was mote often achieved, and the final intervention less often took the form of a mastectomy, when the lesion was classified pre-operatively as malignant $(\mathrm{p}=0.02)$. Conclusion - The outcome of treatment of a needle-localised breast cancer excision is better when the breast lesion is known to be malignant before surgery. 


\section{INTRODUCTION}

The increasing use of mammography in clinical practice and in breast screening progtammes has resulted in the detection of a large number of non-palpable breast lesions. In 1965 the surgical technique of needle-localised open-breast biopsy (NIBB) was introduced as a way of obtaining a histological diagnosis of such lesions. This procedure inwolves petcutaneous placement of a tadio-opaque wire in or near the lesion pre-operatively. The exact position of the wire relative to the lesion is verified with a mammogram. A lump of breast tissue is then removed, the wire and the mammogram being used for guidance. One of the surgeon's intentions in performing an NLBB is to avoid an unnecessarily large excision in the case of a benign lesion. On the other hand it is also important to obtain a wide tumour-free resection margin if the lesion should prove to be malignant. The surgeon is guided in this decision by the pre-operative estimate of the breast lesion's level of malignancy. This may lead to an undesirably high frequency of inadequate breast cancer excision for lesions for which an intermediate level of suspicion has been recorded and for lesions that have given rise to only a low level of suspicion but which unexpectedly turn out to be malignant. Patients whose excised cancers prove to have tumour-involved margins must undergo a second operation so that full tumour cleatance can be achieved. ${ }^{1}$

Pre-operative diagnostic procedures that give the surgeon an idea of how likely malignancy is, are (1) radiological imaging, (2) image-guided fine needle aspitation cytology and (3) image-guided histological needle biopsy. Image-guided histological needle biopsy is curtently considered to be the most accurate procedure. Together with the pre-operative diagnosis, other factors that it was thought might influence the resection margins of a non-palpable breast cancer specimen were: appearance and size of the lesion, type of localisation procedure used, how experienced the surgeon is, size of the excised specimen, and results of specimen X-ray.

The purpose of this study was to determine which factors influence the probability of obtaining tumour-free margins with needle-localised excision of a non-palpable breast carcinoma.

\section{METHODS}

All patients who underwent NLBB at the University Hospital of Maastricht over a 10-year period were identified by reference to the hospital registry. Medical records were retrospectively revicwed for demographic information, radiological characteristics of the lesion, use or not of such pre-operative diagnostic modalities as fine needle aspiration cytology and large core needle biopsy and their results, method of localisation, use of specimen $X$-ray with immediate reporting, final histological diagnosis and margin involvement, any secondary surgery and follow-up. The probability of malignancy for: imaging and fine needle aspiration cytology were scored on a five-point scale. Histological core needle biopsy tesults were scored on a three-point scale. 
On the afternoon before the day scheduled for excision of the non-palpable breast lesion, a radiologist with special interest in senologic radiology performed the needle localisation procedire A hollow needle $(20 \mathrm{G} \times 10 \mathrm{~cm})$ was inserted into the lesion under stereotactic or sonographic guidance. A flexible, single-barbed wire was inserted through the hollow needle (Hawkins IM Flexstrand"M, Medical Device Technologies Inc., Gainesville, FL, USA), A localisation mammogram (craniocaudal and lateral views) was petformed to check and visualise the position of the wire

The excision had the potential of being curative if the operating surgeon knew that the lesion was definitely malignant. The diagnosis was recorded as definitely malignant if either concondant double diagnostic tests poth imaging and fine needle aspiration cytology), $14 \mathrm{G}$ inage-guided histological needle biopsy; or examination of a frozen section sliowed malignancy.

The surgical excision was performed under monitored general anaesthesia. The surgeon was guided by the needle, the initial mammogram, the localisation mammogram and intwa-operative palpation by himself. The excised tissue was marked with a cranial, a lateral and a fascial site bead. After the excision the biopsy specimen was immediately transferted to the Department of Radiology for a single-view X-ray of the specimen, and the vadiologist immediately reported the findings to the operating surgeon (1) entire mammographic lesion ptesent in the biopsy specimen; (2) part of the lesion present in the biopsy specimen; or (3) lesion completely absent from the biopsy specimen. The surgeon then decided whether to end the procechure or to perform an immediate re-excision.

The histopathological macroscopic and microscopic reports gave histological diagnosis, specimen size, lesion size and, in the case of a malignancy, the margin status. The histological diagnosis was divided into categories: (1) normal or benign breast disease (including atypical hyperplasia) or (2) carcinoma in situ or invasive carcinoma (with or without in situ carcinoma). If an immediate te-excision was performed the additional tissue was reconstructed as a part of the tissue to be excised and examined in toto, to allow determination of any residual malignancy and of the margin status.

A median follow-up period of 27 months (1-125 months) was observed to allow any malignancies missed by the NIBB prociedure to be picked up.

\section{STATTSTTCAL ANALYSTS}

A regression analysis was constructed to determine the factors that were infuential in determining the margin status of the excised malignant breast tumours. Demographic, diagnostic and treatment variables eligible for entry into the analysis wete: age of patient, microcaleifications (versus no mictocalcifications) on mammography, pre-operative diagnosis of malignancy (versus benign lesion); year of NLBB, method of localisation (stereotactic wersus sonographic), surgeon's experience (tesident versus specialist surgeora), volume of tissue excised, conclusion (lesion entitely removed versus not-entirely removed) reached on $\mathrm{X}$-ray examination of the specimen, pathological tumout size, whether or not the lesion included DCIS, whether or not the lesion was of the lobular type.

A multivariate logistic regression analysis inchuded all significant variables. Vartables wete retained in the antilysis if they improved significantly $(\mathrm{P} \leq 0.05)$ to fit. Univariate analyses were performed using Chi-squate tests.

A p-value $\leq 0.05$ was considered statistically significant. 


\section{RESULTS}

In the 120 months of the study period, 400 comsecutive NLBB were performed in 370 patients with a mean age of 57 (range 28-85) years. Reasons for the inital diagnostic breast imaging were a suspicious lesion found in the course of the breast cancer screening programme in $247(62 \%)$ of these cases, breast-1elated abnormalities (indeterminate palpable lesions, breast pain, retracted nipple, galactorrhoea) in $106(27 \%$ ). follow-up of breast cancer cases in $27(7 \%$, family history of breast malignancy in $15(4 \%)$ and search for a primary malignancy in patients with metastases from an unknown primary numour in $5(2 \%)$

The lesion was in the left breast in $211(53 \%)$ and in the right breast in $189(47 \%)$ cases. Microcalcifications were present in 190 lesions, 132 of which consisted solely of microcalcifications. The remainder of the lesions were described as circumscribed densiues (178 cases), stellate lesions (54), focal asymmetry $(26)$, and sonographic lesions only (10). Nine lesions were radiologically classified as benign, 120 as probably benign, 244 as probably malignant, and 27 as definitely malignant.

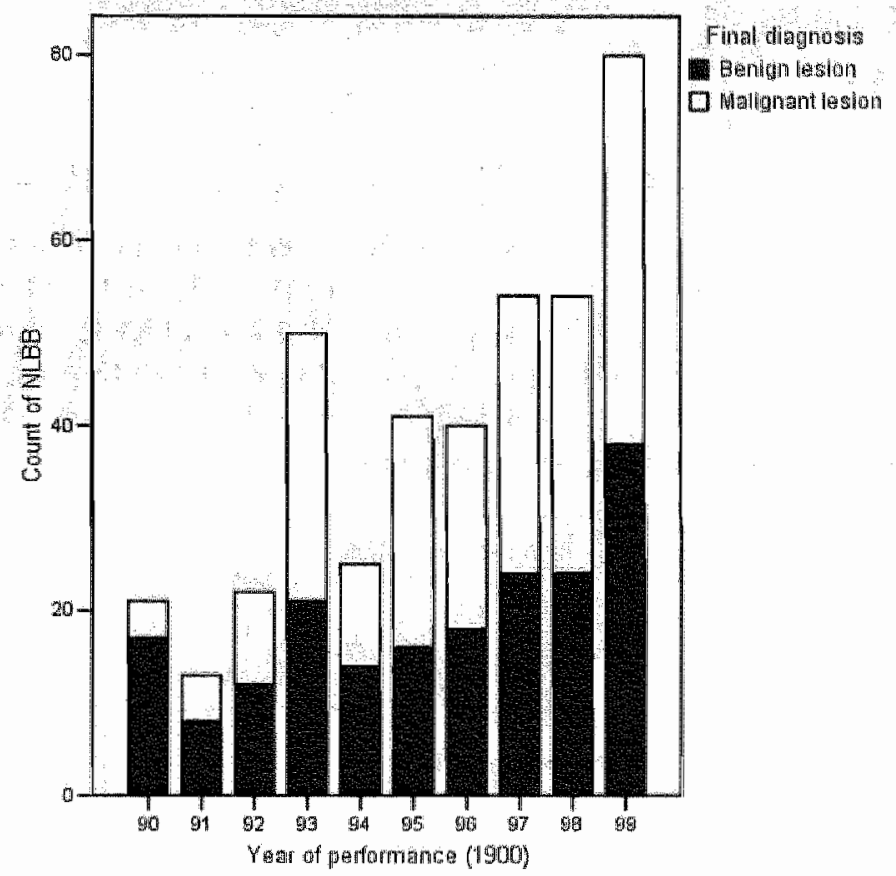

Figure 2.1. Distribution of benign and malignant lesions from 1990 to 1999. NLBB, Needle-localised breast biopsy.

The lesions were localised by a stereotactic method in $83 \%$ of cases and by a sonographic method in $16 \%$. In 3 cases no information was given on the method of localisation. Six stereotactic localisations were unsuccessful for technical reasons (1.5\%). The result of $X$-ray examination of the specimen was available in 351 cases. In 311 of these the 
radiologist teported that the entire lesion was present in the resection specimen $(89 \%)$. In 40 specimen radiograms $(11 \%)$ either the lesion was found to be not present at all (4 cases) or only a part of it was seen ( 36 cases). In 16 (of the 40 ) cases the surgeon decided on an immediate re-excision. In 12 cases tadical excision of the lesions was still not achieved after the NLBB including the re-excision. In 24 cases (out of 40 ) the llesion turned out to be malignant. The surgical procedure was performed by a resident in 292 cases and by a staff surgeon or a surgical oncology fellow in 101 cases. In 7 cases the surgeon's professional standing was unknown.

Figure 2.1 shows the number of benign and malignant lesions per year during the 10-year period. Final histopathological examination of the exised specimens revealed normal or benign breast tissue in $193(48 \%)$, carcinoma in situ in $45(11 \%)$ and invasive carcinoma with or without an in situ component in $162(41 \%)$. The diagnostic performance of $\mathrm{NLBB}$ is shown in Table 2.1. After a median follow-up period of 27 $(1-125)$ months 208 lesions were diagnosed as malignant. The sensitivity and specificity of the NLBB in this study were $97 \%$ and $100 \%$, respectively.

Table 2.1. Diagnostic performance of $\mathrm{NLBB}$ in 400 procedures.

W.

NIBB, Needle-Jocalised breast biopsy.

The malignant lesions included lobular characteristics in 21 cases. The T-classification for the invasive tumours was $\mathrm{T} 1$ in 136 cases $(85 \%), T 2$ in $23(14 \%)$ and $T 3$ in 2 cases $(1 \%)$. In 1 case $T$-staging was not possible. Histopathological examination of the resection margins of the malignant lesions revealed tumour involvement in 142 cases. Re-excision was performed in a second intervention in 112 cases $(45 \%)$. The final surgical intervention performed was a mastectomy in 57 cases.

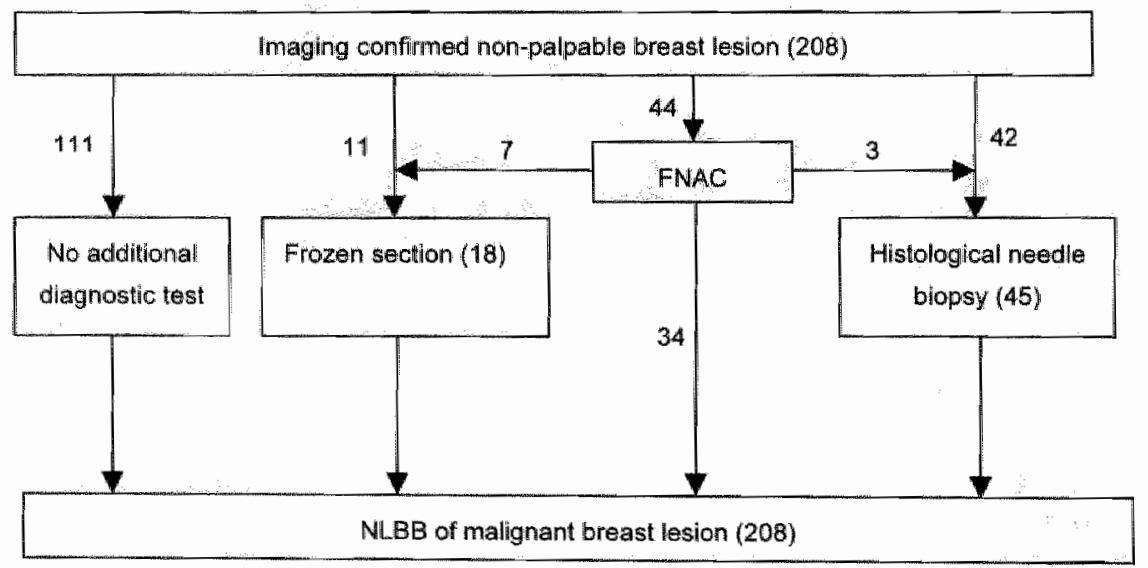

Figure 2,2. Flow chart for application of diagnostic modalities in 208 malignant breast lesions. FNAC, Fine needle appration cytology; NLBB, needle-localised breast biopsy. 
Of the 208 mallignant lesions, 77 were known during the opention to be malignant, as a tesult of the pte-operative work-up (imaging, fine needle aspiration cytology, histological needle biopsy, and/or frozen section). In this study population the positive predictive value of each diagnostic modality was $100 \%$ when the diagnosis was definitely malignant. Some lesions were examined with more than one diagnositic test (Figure 2.2).

\section{REGRESSTON ANALYSIS}

Age of patient, lesion's appearance on maging, pre-operative diagnostic index, year of excision, method of localisation, surgeon's level of experience, specinen size, visibility of lesion on the radiogram of the specimen and tumour histology were included in a multivatiate regression analysis to predict the achievement of tumour-free margins with excision of malignant breast tumours (Table 2.2). The regression analysis showed a strong correlation between tumour-free matgins and a pre-operatively known diagnosis of malignancy. Among the cases in which the diagnosis was known pre-operatively to be definitely one of malignant disease the proportion with tumour-free excision margins was almost three times that in the other cases (Table 2.3, $p<0.001$ ). When the diagnosis of a malignancy is known pre-operatively the chance that the patient will ultimately undergo mastectomy is diminished by wo thirds $(\mathrm{p}=0.024)$.

Table 2.2. Variables (ard codesy in the multivariate tegression athalysis associated with the margingtanus of the excised breast tumour.

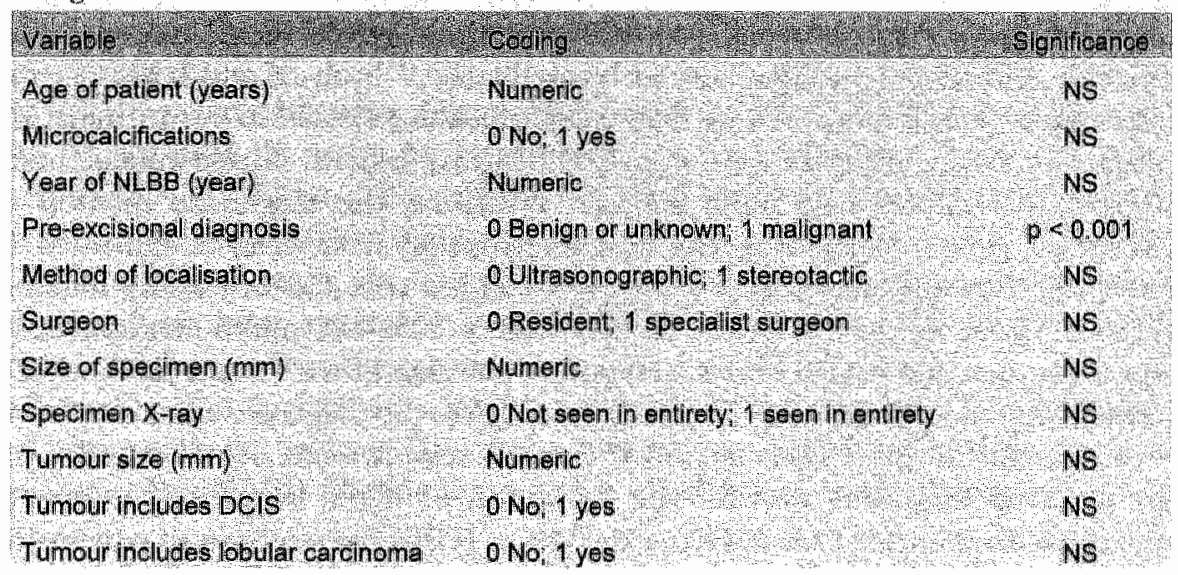

NLBB, needle localized breast biopsy; DCIS, ductal carcinoma in situ; NS, not significant it regression analysis.

\section{DISCUSSION}

This study, reporting on factors that influence the probability of obtaining tumout-free margins after NIBB of non-palpable breast cancer, shows that a pre-operatively confirmed diagnosis of breast cancer is associated with a significantly higher likelihood of tumour-free excision margins. In addition, mastectomy is less frequendy necessary when a lesion is known intra-operatively to be malignant. 
Other authors have found a correlation between residual invasive carcinoma and a high incidence of local recurrence. $2-6$ Patients with non-palpable, screen-detected lesions diagnosed as malignant after NLBB and with matgin inwolvement require further surgery, 1,7

Table 2.3. Tumour free margins and final surgical interyention according to diagnostic index of suspicion of malignancy

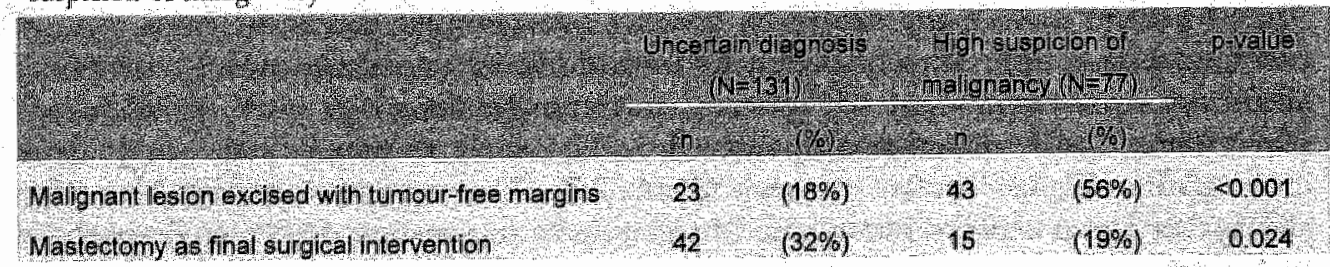

The present study revealed margin inwolvement in $65 \%$ of cases. Different authors have found a substantial propottion, ranging from $56 \%$ to $65 \%$, of cases with unsatisfactory margins among patients with non-palpable lesions in whom needle localisation is performed. ${ }^{8}$ More accurate pre-operative diagnostic procedures resulting in a secure diagnosis before surgery may increase the likelihood of obtaining satisfactory margins with breast-conserving surgery in a larger proportion of patients. Therefore, lesions should be sampled for histological examination by methods that are less invasive than excision and are accurate and cost-effective. Core needle breast biopsy, ${ }^{10-12}$ and, more recently, directional vacuum-assisted breast biopsy, ${ }^{13}$ both of which are performed with stereotactic localisation or with ultrasound guidance, should allow an initial histological diagnosis in the majority of non-palpable breast lesions. Image-guided breast biopsy (TGBB) procedures have now replaced NLBB as the diagnostic method of choice. Accuracy, patient satisfaction and cost effectiveness have been documented for IGBB, which has the advantages of not leaving a surgical scar and of causing minimal residual fibrous tissue in the breast. As IGBB cannot rule out micto-invasion or provide a specimen that allows precise visualisation of the size of the lesion, excision of the entire area of microcalcifications is required to complete the diagnosis when atypia, hyperplasia or carcinoma in situ (CIS) is identified. For this reason, some institutes still favour NLBB as an intial dingnostic tool for the evaluation of highly suspicious lesions (malignant microcalcifications). ${ }^{14}$ Others favour the use of IGBB for selection of patients to undergo NLBB. ${ }^{15}$

An additional advantage of obtaining a diagnosis pre-operatively concerns the planning of the surgical procedure. Diagnosis of invasive breast carcinoma by IGBB allows thorough pre-operative discussion and planning in consultation with the patient. Subsequent surgical treatment, with or without axillary surgery, can be completed in a single procedure. A staging operation such as a sentinel node procedure or an axillary lymph node dissection can be performed at the same time as the initial excisional operation. This combination is less invasive, and restricts the need for anaesthesia and time in hospital.

With a variety of mammographic localisation methods, surgical failure to remove (at least part of) a non-palpable breast lesion has been reported in up to $17.9 \%$ of cases. ${ }^{16}$ 
Hasselgren, ${ }^{17}$ Graham $^{18}$ and Bimston ${ }^{19}$ have also reported limited accuracy of specimet radiogram. All studies have involved single-view specimen radiograms, although it is agreed that a single view is not highly accurate for three-dimensional evaluation in our study we found that the directly reported results of specimen radiograms had only a minor influence. In 24 (out of 40) cases the surgeon decided not to perform an inmediate re-excision. We could not find any clear reasons for these decisions. It seems likely that the surgeon was unsure about the exact location of possible residual malignant tissue in spite of the marked specimen. Even when the surgeon re-excised additional breast tissue because this seemed indicated on the basis of the specimen radiogram (16 cases), in 12 cases the newly excised tissue also still had tumourminolved margins. We therefore have the impression that immediate peroperative reporting of the results of specimen radiography do not prevent tumour-involved tesection matgins. The specimen radiogram has some value in the postoperative evaluation when the diagnosis is still the subject of debate. In such cases a postoperative mammogram might also be valuable, to show residual suggestive tissue in the breast.

The radiological technique used for localisation was ultrasonography in $16 \%$ of the cases in our study population. For patients examined in the last 3 years of this study the corresponding proportion was $32 \%$. Lesions localised by ultasonography should be checked for by ultrasonography in the specimen. In our hospital the specimen is placed in a cup of water for this purpose, with the transducer placed directly on the lump. Rather than evaluating the excised tissue by ultrasound, current investigations are being performed to evaluate the value of intra-operative ultrasound as a tool in the achievement of negative margins. 20

Fïgure 2.1 shows an increasing rate of NLBB and an increasing rate of malignancy revealed by NLBB over the years. In our hospital the incidence of malignant biopsies increased from $19 \%$ in 1990 to $53 \%$ in 1999 . The average of $51 \%$ in our study exceeds the figures in the literature, where the incidence of malignant biopsies ranges from $10 \%$ to $34 \%, 17,21$ The use of more pre-operative diagnostic tools and the improvement of diagnostic procedures have apparently caused a shift in policy, so that now not every benign or probably benign lesion is excised, many being simply left in situ.

We expected to find correlation(s) of (1) experience of the surgeon, (2) numour size, (3) excised tissue volume, and/or (4) lobular tumours or DCIS lesions with tumourinfolved margins after NLBB. We found no such cortelations in our population.

The present study illustrates the advantage of knowing that a lesion is malignant before the NLBB is performed. The proportion of tumour excisions performed with tumourfree margins and the proportion of patients who are treated for their breast malignancy with a breast-conserving procedure were significantly higher in these circumstances than in patients in whom the needle-guided excision was a true diagnostic procedure. We plead for dedicated breast teams who will make concerted efforts to obtain a pre-operative diagnosis, involving pre-operative image-guided breast biopsy in the outpatient clinic if indicated. It is questionable whether immediate reporting of the results of specimen radiography contributes anything to the achievement of tumour-free resection margins. 


\section{REFERENCES}

1. Spiwack, 1 , et a, Margin status and local wecurrence after brens-conserving surgery. Arch Surg, 1994:129(9): $952-6$ discusison 9567 .

2. Schnit, S.], ef al, The relatonship berween mictoscopic maigins of resection and we tusk of local tecurrence th

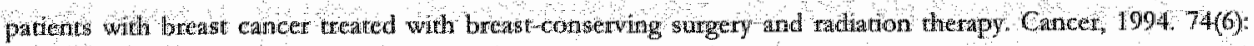
$1740-51$

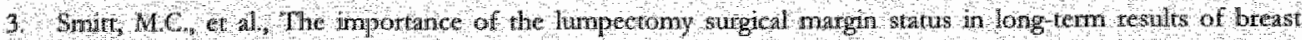
consermation, Cancer, $1095,7602,25967$

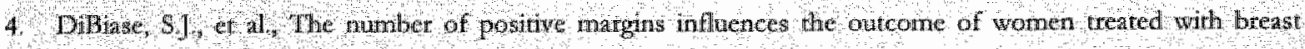
preserrat ton for carly stage breast carcinoma. Cancer, $1998,82(11), 221220$.

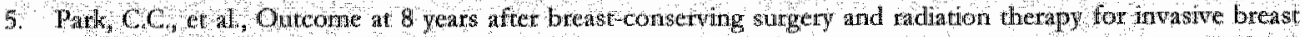

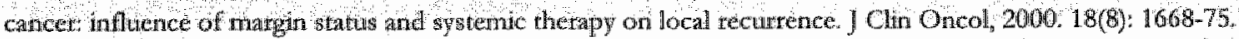

6. Fredrikson, $\mathrm{I}$, et al, Risk foctors for local reurrence after btexst-congerving surgery. BF J 5 urg, 2003.90(9): $1093-102$.

7. Hastrich, D.J, er al., Diagnostic and herapetic aspects of fone wire localization biopsy for umpalpable breast cancer. BrJsurg, 1992,79(0); 103841 .

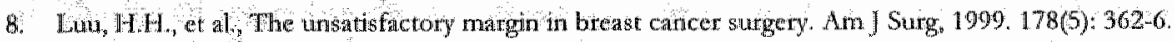

9. Besic, $N$, et al Benst biopsy with wite localization factors influencing complete excision of tonpalpable Carcinoma . Eut Radiol, 2002. 12(11): 2684-9.

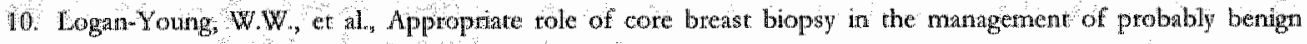
lesion fiee comments]. Rediology, 1994 . 199(2): 313, discussion 313-4.

11. Libeman, L, et al, Stereotaxic core biopsy of breast carcinoma: accuracy at predicting tnvasion. Radiolog, $1995,194(2): 37981$.

12. Dronkers, D., Srereonxic core biopsy of breast lesions. Radiology, 1922. $183(3): 631-4$

13. Berg. W.A, et ale, Ewaluation of 14 - and 11 gauge ditectional, vacum-nssisted biopsy probes and 14 gauge biopsy guns in a breast paredaclimal mode] [see conments]. Radiology, 1997. 205(1): 203-8.

14. Johnson, JM., et all, Image-guded of needle-localized open biopsy of mammographic malignant appearing microcalcifications? ] An Coll Sung, 1998: 187(6): 604-9.

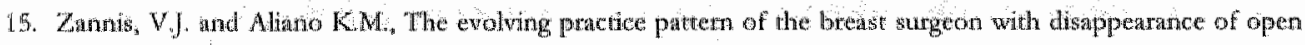

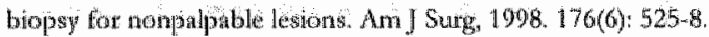

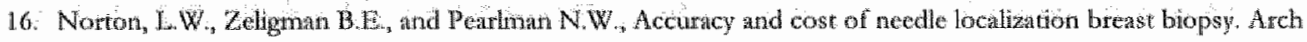
Surg, $1988.123(8) \div 947-50$

17. Hasselgren, P.O, et al. Breast biopsy with needlo localization accutacy of specimen x-ray and management of inissed lesions. Surgery, 1993.114(4): 836-40; discussion $840-2$.

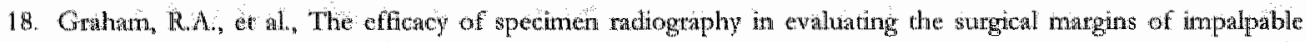
breast catcinoma. AfR An J Roengenol, 1994. 162(1):33-6.

19. Bimston, D.N, Bebb G.G., and Wagmin I.D, Is specinen mammography beneficial? Arch. \$urg, 2000. $135(\mathrm{sep}): 1083 \mathrm{H}$

20. Heny-Tilmata, R. et il., Intraopentive ultrasound and other techniques to achiceve negative margins. Semin Surg Oncol, $2001.20(3): 206-13$.

21. Larrsberg, $L$, et al, Role of wire-guded breast biopsy for diagnosis of malignamt nonpalpable mammographic lesions. Would I Surg, 1999. 23(12): 1279-81. 


\section{CHAPTER \\ III}

Pre-operative estimation of the pathological breast tumour size by physical examination, mammography and ultrasound: a prospective study on 105 invasive tumours

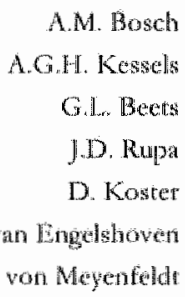

European Joumal of Radiology $2003,48: 285-292$ 
ABstract - The elinical breast tumour size can be assessed pre-operatively by physical examination, mammography and ultrasound. At present it is not clear which modality correlates best with the histological invasive breast tumour size. This prospective study aims to determine the most accurate clinical method (physical examination, mammography or ultrasound) to predict the histological invasive tumour size preoperatively. Methods - Between Octobet 1999 and August 2000, ninety-six women with 105 invasive malignant breast thmours were included in this study. All patients underwent excision and the tumour size was measured on histology. Tumour size was measured by all three modalities in 73 cases. Results were evaluated by calculating correlation coefficients. The examination modalities presenting the best estimation of the pathological tumour size were used in a stepwise linear regression analysis to construct a formula predicting the pathological tumour size from the result of the various diagnostic modalities. Results - The correlation coefficient between ultrasound and pathological size $(\mathrm{r}=0.68)$ was significantly better than the correlations between physical examination and pathological size $(r=0.42)$ and mammographic and pathological size $(r=0.44)$. Physical examination overestimates and ultrasound underestimates breast tumour classification. The most accurate prediction formula was: Pathological tumour size (mm) equals sonographic tumout size $(\mathrm{mm})+3 \mathrm{~mm}$. Conclusion - When comparing physical examination, mammography and ultrasound for the prediction of the pathological size of a malignant breast tumour, ultrasound is the best predictor. The ensuing regression formula determines pathological size as tumour size by ultrasound $+3 \mathrm{~mm}$. However, with the wide $95 \%$ confidence interval of $\pm 11 \mathrm{~mm}$, it remains difficult to predict the exact pathological size for an individual invasive breast tumour. $A$ small deviation in millimetres of the tumour size could lead to a change in treatment and to another prognostic estimate. 


\section{INTRODUCTION}

The size of a malignant breast tumour is an important prognostic factor for the survival of breast cancer patients ${ }^{1-4}$, and a deteminant in the T-classification of the TNM system? The pathological tumour (pT-)stage is assessed by gross pathology (with a correction by microscopic pathology when a part of the tumour consists of in situ disease). The clinical tumour (cT-)stage is assessed by physical examination and imaging. The measurement should be performed by the method "judged most accurate"s. At present most clinicians and reports use $\mathrm{pT}$-staging, as this tumour size will remain the reference standard 6 .

Some therapeutic decisions, however, must be made on the basis of the clinical tumour size, as the pT-stage is not yet available. An example is the indication for sentinel node biopsy. Most surgeons agree that above a given tumour size the procedure is hampered by an unacceptable false negative rate?, leaving the determination of tumour size with important clinical consequences ${ }^{8}$. Another example concerns pre-opentive chemotherapy and its effect on tumour size: both the indication and the definitive staging are dependent on the pre-treatment determination of numour size. These issues raise the question how clinical and pathological tumour size correlate; and which method provides the best estimate of the pathological dimension: physical examination, mammography, on viltrasound.

In addition to the relevance for the individual patient, standardization of clinical bteast tumour measurement is essential when comparing data from different sources. Several studies, mostly retrospective, have addressed the issue of measurement of clinical breast tumour size, but they provide conflicting results $10-18$. Some athors propose a formula that combines physical examination with mammography ${ }^{16}$, while others state that only ultrasound should be used 10 . These conflicting observations prevent a clear consensus.

This prospective study aims to determine the most accurate clinical method (physical examination, mammogtaphy or ultrasound) to predict the histological invasive tumour size pre-operatively.

\section{MEIHODS}

The Medical Ethical Committee of the University Hospital approved a study in which all patients referted fot mammography underwent an additional whole breast ultrasound examination in order to assess the additional value of breast ultrasound. All participating patients consented to the protocol in writing. The present study concerns patients with a malignant invasive breast lesion.

Ninety-six women with 107 invasive malignant breast tumours were primarily treated by surgical excision. The age of patients averaged 61 years (median 61, range $27-86$ ). Two tumours were not completely excised in the first operation and were therefore excluded from this study, leaving 105 breast tumours to be included. All included breast turnours were measured by physical examination when palpable, and by mammography 
and ulrrasound when visible. All measuring modalities were performed in the same order and with full knowledge of the previous results.

Physical examination was performed in upright and supine position by a resident with a special interest in senology. During physical examination the thimb and the index finger enclosed the palpable lesion, and the distance in-between was measured with a ruler. The largest size in any direction was recorded as the tumour size. Also noted were characteristics that may affect the measurement by physical examuation the margin of the tumour (well-defined, or ll-defined), the consistency of the tumour (soft, elastic, firmelastic, or firm), and fixation of the tumour to the surrounding skin and/or chest wall tissue (yes, no). lor the majonty of the lesions a breast surgeon independently assessed tumour size to determine interobserver variation: The first measurement by the resident was used for the evaluations in this study.

\section{IMAGNG PROCEDURES}

Physical examination was mmediately followed by mammography and ultrasound. Mammography was performed using standard craniocaudal and mediolateral oblique projections (Bennet Contour Plus, Oldelft-Benelus, Delft, The Netherlands and Kodak Min $R$ film screen, Rochester, New York). The attending radiologist, specialized in mammography, measured the largest dimension of any mammographic lesion. The size of a breast lesion was measured with a plastic ruler, and using the method described by Flanagan ${ }^{14}$. Spiculated lesions were measured starting from the thickest point of the spicules on each side of the tumour. This tepresented the nucleus of the tumour. The long thin spicules of a stellate lesion were not included in the measurement: When a tumour was associared with microcalcifications that extended beyond the mass lesion, only the principal tumour mass was measured. For a lesion consisting only of microcalcifications the two most distant calcifications were used to define the largest tumour size. Also noted were characteristics that may affect the mammographic measurement: margins of the tumour (well-defined, ill-defined, spiculated), presence of microcalcifications (yes, no) and lesion type (microcalcifications only, mass, stellate lesion, asymmetry). To determine interobserver agreement, another observer evaluated the available mammogtams two months later.

Breast ultrasound was performed using an ultrasound scanner (HD15000, ATL, Bothell-Washington) with a $12-5 \mathrm{MHz}$ handheld linear array transducer. The largest dimension of the tumour was measured during real-time scanning with built in callipers. The same radiologist who interpreted the mammograms, performed the ultrasound measurement. Also noted were chancteristics that may affect the ultrasound measurement: echogenicity of the tumour (hypo-echoic, isomechoic, hyperechoic), mass echo texture (homogeneous, heterogeneous), shape of the lesion (round/oval versus lobulated), mass margin (well-circumscribed, ill-circumscribed), acoustic transmission (shadowing, notmal, enhancement) ${ }^{19}$.

\section{RETERENCE STAND ARD}

The malignant breast tumours were temoved by either lumpectomy or mastectomy. All surgical specimens were subjected to serial section examination and histological evaluation. They were cut into slices of $2 \mathrm{~mm}$ in the sagittal plane. The tumours were 
histologically classified according to the World Health Organtzation and graded by the method of Bloom and Richardson modified by Elston and Ellis ${ }^{20}$. The macroscopicaly recognisable tumour was measured in three dimensions. Invaswe tumour size was defined as the largest diameter of the invasive carcinoma in millimetres of the formalin-fixed pathological specimen. For stellate tumour, only the dimensions of the central corte of the lesion, defined the tumour size $\mathrm{e}^{21,}$ 22. If a component of DCIS was present around the invasive carcinoma a tumour field size was defined. Tumour field size was defined as the largest diameter including inwasive and carcinoma in situ ducts. An in situ component was found along an invasive tumour in 55 cases; in 50 cases only invasive tumour was seetn. Exclusively ductal characteristics were present in 80 tumours, exclusively lobular in 12 Another type of breast cancer was found in 8 cases. The remaining 5 breast cancers thad a combination of histopathological types.

\section{STATISTCAL ANALYSIS}

The analyses of the measurements by physical examination, mammography and ultrasound as separate examination modalities wete performed with those lesions that were palpable $(\mathrm{n}=82)$, visible on mammography $(\mathrm{n}=93)$, or visible at ultasound examination $(n=99)$ respectively. The comparative analyses were performed with those lesions that were palpable as all as visible by both mammography and ultrasound $(\mathrm{n}=73$ ). This is the best population to compare the different diagnostic modalities.

Pearson's correlation coefficients were calculated for the palpated, mammographic and sonographic sizes compared to the pathological size. Differences in correlations were tested for significance ${ }^{23}$. Scatter plots were drawn, with best fit and $95 \%$ prediction interval lines with the pathological size as the dependent variable. Reliability of palpated and mammographic size was ascertained by calculating Pearson's correlation coefficients between the initial and the second measurements. Only the initial measurements were used for futher analyses.

A stepwise linear regression analysis determined the influence of the palpated tumour size, palpated margin of the tumour, the consistency of the tumour, and fixation of the tumour to the surrounding tissue on the estimation of the pathological tumour size by palpation. Another stepwise lineat regression analysis determined the influence of the mammographical tumour size, the mammographic margin of the lesion, whe lesion type, and the presence of microcalcifications on the estimation of the pathological numour size on the mammogram. A third stepwise linear regression analysis determined the influence of the sonographic tumour size, the margin of the lesion, the echogenicity of the tumour; the shape of the tumour, and the background of the tumour on the estimation of the pathological tumour size by ultrasound.

The overclassification and underclassification in T-classification based on clinical (c-T) versus pathological ( $\mathrm{p}-\mathrm{T}$ ) size were calculated. Whether one diagnostic modality showed more under- or overclassification than another modality, the discordant classifications of two diagnostic modalities wete compared with a McNemat test. 


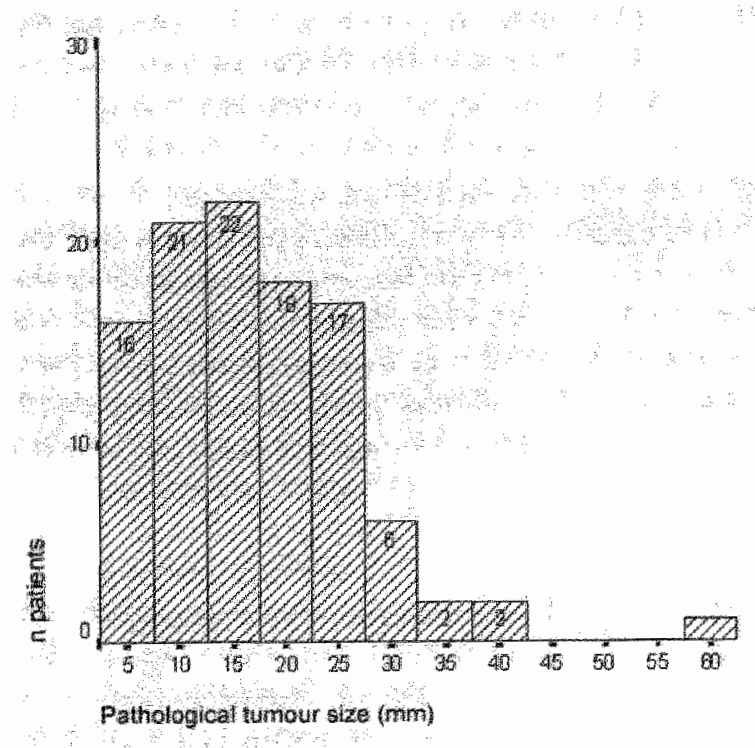

Figure 31. Distribution of the pathologeal wriour size of all 105 in

As an example, and because of its clinical, prognostic implications, receiver operatug characteristic (ROC Jarves were gaphed for tumours larget than $20 \mathrm{~mm}$ (category T2 vs T1). The areas under the ROC-curves (AUC-ROC) were calculated for physical examination, mammography and ultasound with the cut-off points at $20 \mathrm{~mm}$ in pathological size, and differences were tested according to the method of Hanley et al?

Ftom a stepwise linear tegression analysis a formula was derived, whth the examination modality(ies) presenting the best estimate of the pathological tumour size.

A p-value of smaller or equal to 0.05 was considered statistically significant.

\section{RESULTS}

The pathological tumour size of the 105 malignant breast tumours averaged $17 \mathrm{~mm}$ (sd 9.4) (Figure 3.1). Analyses were perforned by measurement of both pathological invasive tumour size and pathological tumout field size. Invasive tumout size measurement correlated best with all dignostic modalities. This size was therefore used in all futher analyses.

Out of the total group of 105 tumours, 82 were palpable so that a maximum diameter by physical examination could be recorded. The mean palpated tumour size was 25 mm (sd 126), whereas the mean pathological size of these palpable tumours was $19 \mathrm{~mm}$ (sd 10.0). The correlation coefficient between the size of the palpable tumours by the initial observer and the pathological size is $0.47(\mathrm{p}<0.01)$. In 23 instances tumours were not palpable. These tumours had a mean pathological diameter of $10 \mathrm{~mm}$. A substantial part 
of the cases $(\mathrm{n}=61)$ underwent a second independent physical examination by a breast surgeon at the outpatient clinic of the department of surgery. The correlation coefficient between the two observers was $0.87(p<0.01)$. There were no tumout chatacteristics upon physical examination (palpated margin of the tumout, consistency of the tumout, tumour fixation to the surrounding tissue) that influenced the prediction of the pathological tumour size significantly.

From the mammogram 93 tumour sizes could be measured. Another four were seen, but an exact diameter could not be determined, because of extremely blurred matgins fof which the radiologist could not measure a diameter within a margin of \pm 1 cm). Stellate lesions were found in 46 cases, 38 lesions were described as masses, 5 as microcalcifications only, and 4 lesions were described as architectural distortion. In $24 \%$ (22) of the lesions microcalcifications were present on nammogtaphy. The mean tumour size determined on mammography was $21 \mathrm{~mm}$ (sd 11.0). The mean pathological size of these 93 tumours was $17 \mathrm{~mm}$ (sd 9.0). The correlation coefficient between the suze of the mammographically measured tumours by the initial observation and the pathological size was $0.44(p<0.01)$. To ascertain the reliability of the first measurement a substantial part of cases $(n=71)$ underwent a second blinded measurement. The correlation coefficient between the two observers was $0.84(\mathrm{p}<0.01)$. There were no lesion characteristics on the mammogram (lesion type, margin of the lesion, presence of microcalcifications) that influenced the prediction of the pathological tumour size significantly:

Ninety-nine lesions were visible by ultrasound and tumour size of these 99 tumours was sonographically defined. The lesions were manly hypo-echoic (98), irtegular (92) and with attenuated posterior echo intensity (53) or no changes in posterior echo (38) lesions. The mean tumour size in breast ultrasound was $17 \mathrm{~mm}$ (sd 7.8). The mean pathological tumour size of these 99 breast tumours was $17 \mathrm{~mm}$ (sd 10.0). The correlation coefficient between the size of the sonographically measured tumours and the pathological size was $0.71(\mathrm{p}<0.01)$. There were no lesion characteristics on ultrasound (margin of the ultrasonographical lesion, echogenicity of the lesion, shape of the lesion, background of the lesion) that influenced the prediction of the pathological tumour size significantly.

Figure 3.2 shows scatter plots of the measured points by physical examination, mammography and utrasound. Best fit and the $95 \%$ confidence interval lines ate shown.. Correlation coefficients of the palpation plot, the mammography plot and the ultrasound plot are $0.437,0.444$ and 0.710 respectively with a $p<0.001$ each. The figures cleatly show the wide $95 \%$ confidence intervals of $\pm 23 \mathrm{~mm}$, $\pm 20 \mathrm{~mm}$, and $\pm 11 \mathrm{~mm}$ for physical examination, mammography and ultrasound respectively.

Tumour size could be measured by all three modalities in 73 cases, which was therefore accepted as the best population to compare the different diagnostic modalities. The mean pathological tumour size of these 73 tumours was $19 \mathrm{~mm}(\mathrm{sd} 9.0$ ). The correlation coefficient between ulttasound and pathological measurement $(\mathrm{t}=0.68)$ was significantly higher than the correlations between palpated and pathological measurements $(\mathrm{r}=0.42, \mathrm{p}=0.03)$ and mammographic and pathological measurements $(\mathrm{r}=0.4 .4, \mathrm{p}=0.05)$. 

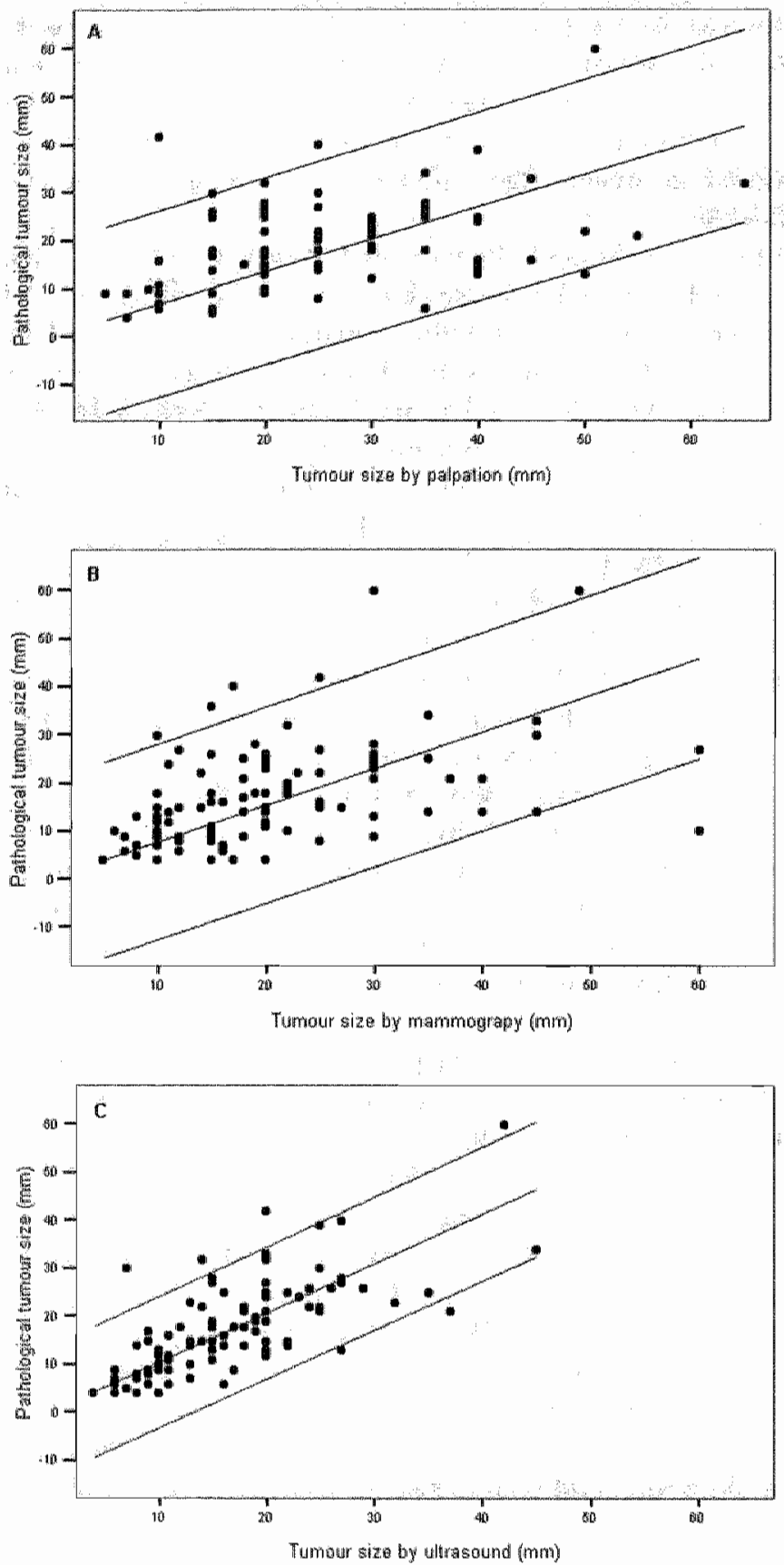

Figure 3.2. Scatterplots, best fit, and $95 \%$ prediction interval lines of the pathological tumour size and the tumour size by palpation $(A)$, by mammogtaphy $(B)$, and by ultrasound $(\mathrm{C})$ 
Table 3.1 shows the under- and overestimation in the $\mathrm{p}-\mathrm{T}$-elassification for $\mathrm{T}, \mathrm{T} 2$ and T3 tumours. Ultrasound underestimated the tumour size significandly more frequenty than mammography and physical examination $(\mathrm{p}=0.03$ and $\mathrm{p}=0.0001$, respectively). The difference between the numbers of over- or underestimation of mammography and physical examination were not statistically significant $(\mathrm{p}=0.11)$,

Table 3.1. Total numbers and percentages ower-, ander- and correct estimation of the $\mathrm{PT}$-chassification (T1, T2 and $\mathrm{T} 3$ ) by physical examination, mammogiaphy and ultrisound.

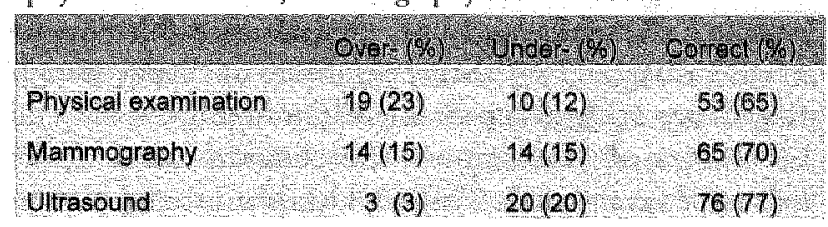

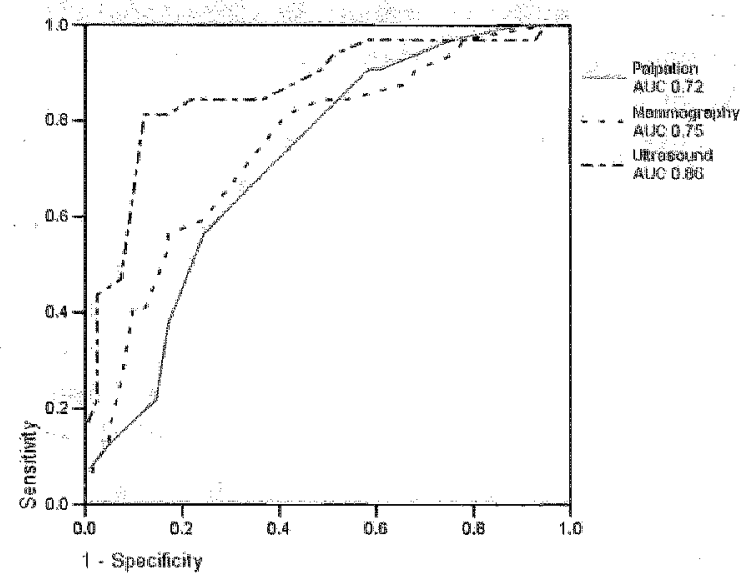

Figure 3.3. Receiver operating characteristic (ROC) - cunres fot the correct prediction of $\mathrm{T} 2$ tumours $(>20 \mathrm{~min}) \mathrm{by}$ palpation, maminogtaphy and ultrasouind.

$A \cup C_{\text {n }}$ area under the ROC-arve.

For a correct determination of ( $T$-) classification latger than $20 \mathrm{~mm}$, figure 3.3 shows the ROC-curves of the three examination modalicies for $\mathrm{T} 2$ classification of breast tumours. Ultrasound correctly predicts a T2-tumour significandly more often (AUC-ROC $=0.86$ ) than physical examination (AUC-ROC $=0.72, \mathrm{p}=0.01$ ) and mammography (AUC-ROC $=0.75, \mathrm{p}=0.04$.

Finally, a formula was constructed to estimate pathological tumour size. A lineat regression analysis considering palpation, mammography and ultrasound determined ultrasound as the only significant factor in the estimation. Thus pathological morr size (mon)

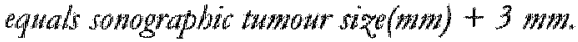




\section{Discussion}

When comparing physical examination, mammography and ultrasound for the prediction of the pathological size of a malignant breast tumour, ultrasound is the best predictor $(x=0.71, p<0.001)$. The ensuing regression formula determines pathological size as tumour size by ultrasound $+3 \mathrm{~mm}$. However, with the wide $95 \%$ confidence interval of I $11 \mathrm{~mm}$, it remains difficult to predict the exact pathological size for an individual rumour.

The method of measuring a breast tumour size is obviously different for physical examination, mammography, ultrasound and histopathology. This may account for some of the disagteement between these methods. In physical examination, the palpating fingers are enclosing not only the tumour, but also the skin and subcutaneous tissue on both sides of the tumour. The clinician has a tendency to measure in centimetres or halves of centimetres. This could explain the overestimation of the tumour by $10 \mathrm{~mm}$ on average. This overestimation is consistent, as shown by the high interobserver agreement. When the palpated tumour size rather than the pathological size is used in decisionmaking, patients are likely to be overtreated. Palpation is still necessary to determine the possibility of palpation-guided fine needle aspiration and the uselessness of a needlelocalised open breast biopsy.

By mammography the centre of a mass is measured, not the microcalcifications or thin spicules is measured, as described by Flanagan ${ }^{14}$. It has been suggested that the magnification of the X-ray technique could explain some of the observed overestimation. Theoretically, mammographic imaging includes a magnification. Only few authors mention this phenomenon and even fewer attempt to compensate for $\mathrm{it}^{14,} 16,25$. The magnification factor in our study was approximately 1.04 , and therefore cannot have contributed much to the overestimation. Another explanation could be the shrinkage of the rissue by fixation in histopathological procedures, although this has never been documented. The inter-observer agreement of the mammographic measurements was substantial. This is better than, or in agreement with, results presented in the literature ${ }^{26.30}$. Although ultrasound performs better in measuring solid lesions, mammography remains the most important modality in cases of non-palpable microcalcifications.

In sonographic measurement the presence of blurred margins or a 'halo' on the monitor can cause some difficulties. The set-up of our study did not allow for a second, completely independent, ultrasound evaluation by another radiologist, and therefore precluded determination of the interobserver variability.

Other diagnostic modalities to measure a breast tumour size such as MRI have been shown reliable and accurate ${ }^{13,31}$, although not yet widely used in daily practice.

In a tetrospective study of 200 patients with breast cancer, Pain et al. ${ }^{16}$ concluded that the three diagnostic modalities, physical examination, mammography and ultrasound, had a similar accuracy for predicting the pathological size. The authors found that physical examination overestimated small tumours and underestimated large tumours, that mammography underestimated large tumours, and that ultrasound underestimated all tumours. Pain's pathological breast tumour size was best predicted with a simple formula including only physical examination and mammography measurements: Pathological size $=$ $0.5 *$ mannwographic size $+0.5 *$ size by physical examimation. 
A stepwise linear regression analysis on the cases in our study leawes only ultrasound as a significant determinant of pathological tumour size. From our data we conclude that when a breast lesion can be measured by ultrasound, this presents the best estimate of the pathological tumour size.

Correlation coefficients between clinical and pathological tumour sizes have been reported to range from 0.68 to 0.79 for physical examination ${ }^{17}, 32$, from 0.48 to 0.84 for mammography ${ }^{13,31}$, and from 0.47 to 0.92 for ultrasound ${ }^{13}$, 31 . From these studies it is not clear which is the most accurate modality to estimate pathological tumour size. The correlation coefficients for the three examination modalities found in our study are not as good as some in the literature. Difference in study design could explain this discrepancy: most of the reported studies are retrospective, in which the original examination is re-evaluated at a later stage, with the specific intent to calculate the correlation coefficient. Our study is prospective, and the measurements reflect the procedures as they ate performed in daily routine. In a prospective study Madjar et al. ${ }^{15}$ conclude that ultrasonographic measurements are far superior to physical examination and mammography. Our results are in agreement with this observation.

The pathological measurement includes the whole extension of the tumour, even when it consists of microcalcifications or spicules. Although histological examination of the tumout size may not always be completely accutate, it is by convention used as the reference test ${ }^{33}$. The pathologist distinguishes between a field and an invasive tumour size. We used the invasive tumour size rather than the tumour field size as the reference for all examination modalities. This approach is in concordance with the TNM system, which considers only inwasive tumour size.

The pre-opetative size of a breast tumour is a factor that plays a role in the decision to perform a sentinel node biopsy or a complete axillary cleatance. The larger a breast cancer, the higher the a ptiori chance for lymph node metastasis. With a reported sensitivity of $90-95 \%$, the negative predictive value of the sentinel node procedure in large tumours is lower than in small tumours. There is a critical size above which the chance of a procedure being false negative outweighs the advantages of sparing an unnecessary axillary clearance. At present there is no agreement on this critical size. A cut off point of 20 or $30 \mathrm{~mm}$ has been suggested"34. As shown in table 3.1 st substantial amount of misclassification will occur depending on how the clinical size is assessed. One step further in the management of the axilla is the proposal to omit axillary surgery for T1a tumours ( $5 \mathrm{~mm}$ or smaller) ${ }^{35-38}$. This proposal is based on retrospective series using the pathological size. Tumours of this size are generally not palpable, and to obtain a reasonably accurate estimation of the tumour size, our study suggests the use of ultrasound. Other areas where the size of the tumour is an important factor in the management are the choice between breast conservation and amputation, and the administration of neo-adjuvant systemic therapy for large tumours (T3 or larger than $30 \mathrm{~mm}$ ), in order to facilitate breast conservation therapy 39,46 . Tumour size evaluation after neo-adjuvant systemic therapy is another interesting topic of discussion, because the chemotherapy might influence the palpability and the visibility of the maliguant tissue left behind.

Because of the inaccuracy in predicting pathological tumour size, we recommend caution in the pre-operative estimation of the clinical T-classification. A small deviation in 
millimetres of the tumour size could lead to a change in treatment and to another prognostic estimate. Whenever pre-operative clinical $T$-staging is used in decision-making in the treatment of breast cancer, the tesults of our study indicate that tumour size should be determined by ultrasound whenever possible. 


\section{REFERENCES}

1. Veronesi, $\mathrm{U}_{3}$, et al, Sentinel lymaph node biopsy as an indicator for axillary dissecrion un eady' breast cancer. Eur J Carcer, $2001,37(4), 4548$.

2. Cowen, $\mathrm{D}$, er all, Local and distant tecurrence after conserwative management of wery low rok, breast cancer are dependent events: a 10-yerar follow-up. Int I Radiat Oncol Biol Phys, 1998. 41(4): 8017.

3. Dongen van, JA, et al, Factors influencing local tellapse and survival and tesolts of salvage treatment after breast-conserwing therapy in operable breast cancer BORTC trial 10801, breast conservation compnted with mastectomy in TNM stage I and II breast cancer. Ear I Cancer, $1992.28 \mathrm{~A}(4-5)$. 801 -5.

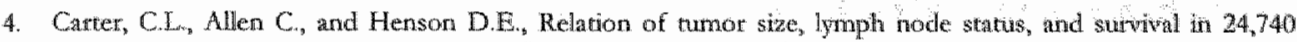
breast cancer cases. Cancer, 1989, 63(1): 181-7\%.

5. Sobin, L.H. and Wittekind C., TNM Classification of malignant tumours. Breast muours (ICD O C50), 1997 .

6. Critical assessment of the clinical TNM system in breast ancer. Report from the Yorkshure Breast Cancet Group. Br. Med ), 1980, 281(6233): 134-6.

7. OHea, B. J et al, Sentinel lymph node biopsy in breast cancer: initial experience ant Menorhil slontikettering Cancer Center J Am Coll Surg, 1998. 186(4):423-7.

8. Noguchi, $M_{*}$ Sentinel lymph node biopsy and bteast cancer. British journal of surgery, 2002. 89(1):21 34.

9. Roumen, RM., et al., [Summery of de guideline "Sentinel node biopsy procedure bru breast cancert. Ned Tijdscly: Geneeskd, 2000. 144(39): 1864-7.

10. Pierie, J.P.E.N, et al., Clinical assessment, mammography and ultrasonography as methods of measuring the size of breast cancer: comparison. The Brewst, 1998. $7: 247.50$.

11. Finlayson, $C_{A} A$ and MacDermott "I"A., Ultrasound can estimate the pathologic size of infiltating ductal Carcinoma. Arch Surg, 2000, 135(2): 158-9

12. Skaane, $\mathrm{P}$. and skjorten $\mathrm{F}$., Ulrasonogmaphic exahation of invaliwe lobulat carcinonat. Acta Radiol, 1999. 40(4): $369-75$.

13. Yang W.T., Sonographic, Magnetic Resonance Imaging, and nammoguphic Assessment of Prewoperative Size of Breast Cancer. I Ultrasound Med, 1997. 16:791-7.

14. Flanagan, F.L., et al, Invasive breast cancer: manumogaphic measurement. Radiology, 1996, 199(3): 819.23.

15. Madjar, H, Ladnet, H.A, Sauerbrei, W. Oberstein, A., Promapeler, H, Pfleideter, A, Preoperaiwe staging of breast cancer by palpation, nammography and high resolution ultasound. Ultrisound Obster: Gynecol. 1993. 3: $185-90$.

16. Pain, J.A, Ebbs, S.R., Hern, R.P.A., Lowe S, Bradbect J.W., Assessment of Lreast cancer size: at comparison of methods. European Journal of Surgical Oncology, 1992. 18: 44-8.

17. Fornage, B.D., Toubas, O., Motel, M, Clintal, mamnographic, and sonograptic detemination of preoperative breast cancer size. Cancer, 1987.60: 76571.

18. Hicken, T.J, et al, Correlating sonography, mammography, and pathology in the assessment of breast catace size. Am J Surg, 2001. 182(4): $351-4$

19. Baker, J.A, er ail., Sonography of solid breast lesions: observer variability of lestow description and assuessment Am ] Roentgenol, 1999. 172(6): 1621-5.

20. Elston, C.W. and Ellis I.O, Pathological prognostic factors in breast cancer. I. The value of histological grade in breast cancer experience from a large stady with long-term follow-up. Histopathology, 1991, 19(5): 403-10.

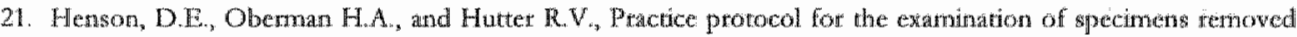
from patients with cancer of the breast: a publication of the Cancer Committec, Collge of American Pathologists. Members of the Cancer Commitee, College of American Pathologists, and the Task Force for Protocols on the Examination of Specimens from Patients with Breast Cancer. Arch Pathol Lab Med, 1997. 
$121(1), 27-33$

22. Schnte, \$I and connolly JL, Processing and cwaluatom of breast excision specimens. A clinically oriented

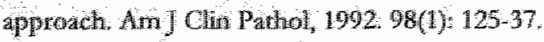

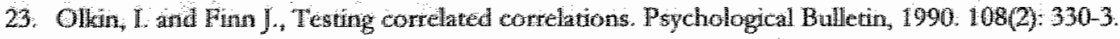

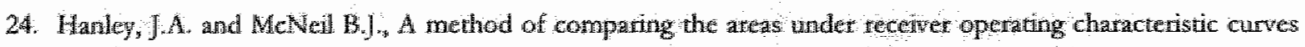
dexived from the same cases. Radrology, $1983,148(3)$. $839-43$

25. Sphits, N., et al lroprowed determination of brease cancer size in mammograptry. Technol Health Care, 1996. $4(2) \div 163-9$

26. Ciccone, $G$, et all, Inter-bbserver and inera-observer wariability of mammogran inempretation: a field study. Eur JCancer, $1992.28 \mathrm{~A}(6,7) ; 1054-8$.

27. Elmore, ].G., et all, Vargability in radiologists" interpretations of mammograms [see comments]. N Engl] ] Med, 1994. $331(22): 1493-9$.

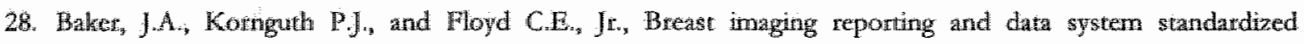
marmmographyy lexicon: observer variability in lesion description [see comments]. Am If Roentgenol, 1996. 166(4): $: 773-8$.

29. Kerlikowske, K., et al. Variability and accuracy in mammographic interpretation using the American College of Radiology Breast Imaging Reporting and Data System. J Narl Cancer Inst, 1998. 9023): 1801-9:

30. Berg, W., et al, Breast. Imaging Reporting and Data System: inter- and anteabserver variability in feature andilyis and final assessment. Am J Roentgenol, 2000. 174(6): 1769-77.

31. Dawis; P.L. at al. Accuracy of breast caracer meastuements with MR imagning, US, and mammography. in RSMA. 1994.

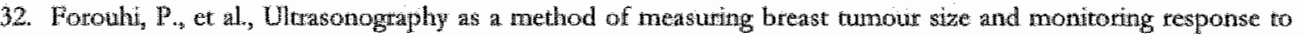
primary systemic treatment. Br J Surg, 1994. 81(2): 223 5 .

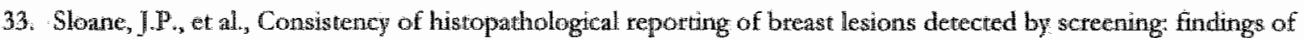
the U.K. National External Quality Assessment (EQA) Scheme. U. K. National Coordinating Group for Breast Screening Pathology. Eirr ] Cances, 1994, 10(9): 1414-9.

34. Seidman, J.D., Schnaper I. A., and Aisnex S.C., Relationship of the size of the invasive component of the primary breast carcinoma to axilary lymph node metastasis. Cancer $1995.75(1)$ : 65-71.

35. Greco, $\mathbb{M}$, et al, Breast cancer patients treated without axillary surgery: clinical implications and biologic analysis [sec conwnerarg]. Amn Surg, 2000. 232(1): 1-7.

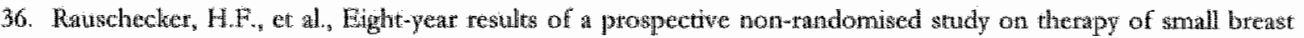
cancen: The German Breast Cancer Study Group (GISG). Eur J Cancer, 1998. 34(3): 315-23.

37. Burth, A. Crigig P.H, and Silverstiot M.J. Predlictors of axillary lymph node meastases in patients with T"l breast: cartinoma: Cancex, $1997.79(10): 1918-22$

38. Silverstein, M.J, at al. Axillary lymph node dissection for Tla breast carcinoma. Is it indicated? Cancer, 1994 . $73(3): 664-7$

39. Herrada, Jns al, Relative whe of physical examination, mammography, and breast sonography in evaluating the size of the prinamy tumor and regional lymph node metastases in women receiving neoadjurant chemotherapy for Locally advanced breast carcinoma. Clin Caneer Res, 1997, 3(9): 1565-9.

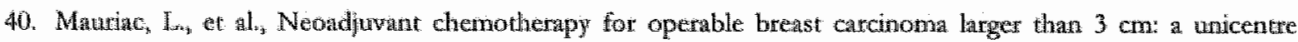
randomized trial with a 124-month medhan follow-up. Institut Bergonie Bordeaux Groupe Sein (IBBGS). Aru Oncol, $1999,10(1): 47-52$ 


\title{
CHAPTER IV
}

The additional diagnostic value of ultrasonography in the diagnosis of breast cancer.

Arch Int Med 2003; 163:1194-1199

\author{
K. Flobbe \\ A.M. Bosch \\ A.G.H. Kessels \\ G.L. Beets \\ P.J. Nelemans \\ M.F. von Meyenfeldt \\ J.M.A. wan Hingelshon
}


ABSTRACT - The use of ultrasonography in diagnostic breast imaging is increasing. Restricting ultrasonography to subgroups of patients who benefit most, would result in a more efficient and effective application. This study assessed the diagnostic value of ultrasonography as an adjunct to mammography and physical examination in the diagnosis of breast cancer and the feasibility of selecting subgroups of patients who benefit the most. Methods - Between October 01, 1999, and August 01, 2000, all consecutive patients referred for breast imaging underwent additional ultrasonography after matnmography and physical examination. Results were scored on a 5-point grading scale of increasing suggestion of malignancy: Pathology results during 12 months of follow-up were used as the criterion standard. Receiver-operating characteristic curve analysis assessed the diagnostic value of ultrasonography in the whole population and in subgroups of patients according to indication for referral and age. Results - a total of 3835 breasts were examined in 2020 patients, with a $6.3 \%$ prevalence of breast cancer. Breast ultrasonography detected 8 extra malignancies and correctly downgraded 332 cases from a positive to a negative diagnosis (iê, from a suggested malignancy to no malignancy). Receiver-operating characteristic curves showed a significant improvement in diagnostic value by adding ultrasonography to mammography and physical examination (area under the curve for physical examination + mammography + ultrasonography vs physical examination + mammography, 0.99 vs $0.95 ; \mathrm{p}=0.002$ ). The diagnostic yield improved significantly in patients referred for palpable breast lumps $(p=0.004)$ or referted from the national breast cancer screening programme $(p=0.05)$. Less pronounced was the value in patients referted for other symptoms or for follow-up of a prior breast malignancy. When breast imaging of the contralateral breast or of asymptomatic patients referred for reassurance or follow-up of a prior benign lesion was performed, the value of additional ultrasonography remained undefined because of the few malignancies found. Conclusions - The systematic application of breast ultrasonography imptoved the ovetall diagnostic yield. The diagnostic value increased most in patients with palpable breast lumps and in patients referred with abnormal screening mammograms. 


\section{INTRODUCTION}

With a lifetime risk of $10 \%$ breast cancer is a major public health problem for women in Western countries ${ }^{1}$. Its diagnosis and treatment are creating financial burden to the health care system.

In addition to mammography, ultrasonography has become the most widely used imaging method in the diagnosis of breast disease, especially in patients with palpable masses and normal or non-conclusive mammographic results ${ }^{2-4}$. Numbers from our hospital show that the application of additional ultrasonography has increased from $28 \%$ of patients referred for mammography in $1994^{5}$ to more than $35 \%$ in 1999 . This is partly because of wider availability and accessibility, broadening clinical indications, and the idea that physicians believe they are less likely to be blamed for doing more testing than for doing too little $e^{6}$. As a result, many examinations are actually redundant and will lead not only to increasing health care costs, but also to unnecessary inconwenience and discomfort to the patient, an unnecessary workup because of false-positive results, and longer waiting lists.

To reduce this health care problem and to aim for more effective and efficient use; additional ultrasonography should be restricted to those subgroups of patients who benefit most from it:

Several studies ${ }^{7 \cdot 12}$ have assessed the diagnostic value of clinically indicated breast ultrasonography as an adjunct to mammography. Despite the fact that combining mammography with ultrasonography resulted in a higher sensitivity, in 3 studies $7.8,19$ the increase in sensitivity was reached at the expense of a decrease in specificity. None of these studies have applied ultrasonogtaphy systematically in consecutive parients to obtain evidence-based information on subgroups of patients with the highest diagnostic yield.

The aim of this prospective study was, therefore, to assess the diagnostic value of breast ultrasonography as an adjunct to mammography and the physical examination in a consecutive set of patients referred for diagnostic breast imaging. Furthetrnore, the feasibility of selecting subgroups of patients who benefit most from additional ultrasonography was studied.

\section{METHODS}

Between October 01, 1999, and August 01, 2000, all consecutive patients teferred to ou: radiology department for diagnostic breast imaging underwent additional ultrasonography after physical examination and mammography.

Patients were informed about the study by mail preceding their schedulled visit and in the department before their imaging examination, after which informed consent fotms were signed. Patients were excluded from the study when ultrasonography could nor be performed because of logistic reasons or when no informed consent was given. In the Netherlands, a system of collective health insurance makes health catre available to the whole population; therefore, no patients were excluded from the study because of an inability to pay or lack of insurance. 
Investigations were performed in fixed order during a single visit. Bilateral physical examinations, performed while the patients were in standing and sitting positions, were followed by standard craniocaudal and mediollateral oblique mammogtams (Siemens Mammomat-2 unit / Kodak Min-R film screen combination), then followed by whole breast ultrasonography (model ATL5000, $12.5 \mathrm{MHz}$ linear array transducer, Philips Medical Systems, Best, The Nethetlands), Conforming to clinical practice all examinations were performed and interpreted with full knowledge of prior test results.

Tests were performed by a team of tadiologists with more than 5 years' experience in diagnostic breast imaging. In one patient, all examinations were performed by the same radiologist. In addition, study procedures were monitored and tegistered by a resident who was present at all examinations of all patients.

All televant patient characteristics and the description, size and location of lesions found at the different diagnostic examinations were registered in a standardized fashion. The diagnosis, based on physical examination, mammography and ultrasonography was scored separately per breast on a 5-point grading scale with increasing suggestion of malignancy ( 1 indicates a normal result; 2 , benign lesion; 3 , probably benign lesion; 4, suggestive malignant lesion; and 5, malignant lesion, ( 0 was an inderminate result)), based on the breast imaging reporting and data system lexicon for mammography and under development for ultrasonography by the American College of Radiology.13,14

In addition to these separate diagnoses, a combined diagnosis of physical examination and mammography together was calculated by taking the maximum diagnostic score of these modalities. Finally, a final diagnosis based on physical examination, mammography and ultrasonography together was defined mathematically as the maximum score of the modalities in case of a benign or a malignant diagnosis. When scores differed more than one grade of suggestion of malignancy or when either of the two modalities included a probably benign score, the overall dingnosis of the radiologist interpreting all examinations ruled. The additional diagnostic value of ultrasonography was determined by comparing the accuracy of physical examination + mammography + ultrasonography with the accuracy of physical examination + mammography.

Indeterminate plysical examination results (score, 0 ), as in cases of mastopathy, were recoded as benign (scote, 2) and indeterminate mammography or ultrasonography tesults were recoded as probably benign (score, 3), for analysis.

The criterion standard for the presence or absence of breast cancer was determined by pathologic results of histological core needle biopsies, excision biopsies and other surgical interventions during a follow-up of 12 months. An additional 2 months was added accounting for administrative routing of test results at the end of the follow-up period.

Pathologic results were retrieved from the hospital pathology department and the Dutch Network and National Database for Pathology, to which all Dutch hospital pathology departments are linked. Breast cancer status was considered negative when no pathologic condition was reported in either system.

Receiver-operating characteristic (ROC) curves were constructed for the imaging results of physical examination, physical examination + mammography, and physcial examination + mammography + ultrasonography. Areas under the curve (AUCs) were callculated as a measure of the diagnostic performance, and differences were calculated 
and tested according to the methods of Hanley and McNeilis, 16 . Furthermore, ROC curres were analyzed for subgroups of patients according to indications for referral and age.

\section{RESULTS}

There were 2720 scheduled imaging examinations; of which 112 were cancelled and 84 were excluded from the study because patients had been included on earlier visits. Fot 279 patients, additional ultrasonography was not realized because of logistical reasons, and 225 patients refused to sign informed consent form. The patients excluded from the study had a comparable prevalence of breast cancer, age distribution, reason for referral, and imaging interpretation:

A total of 2020 consecutive patients wete included in the study and underwent a physcical examination, mammography and ultrasonography of both breasts. The population consisted of 2000 women and 20 men (mean age, 50.2 years; tange $16.8-90.3$ years). Patients were referred by general practitioners $(n=1044)$, surgeons $(n=712)$ and other specialists $(n=264)$. Indications for patient referral were as follows: a palpable breast lump ( $n=470)$; other breast symptoms, such as pain or skin or nipple abnormalities $(n=486)$; follow-up of a prior breast malignancy $(n=438$ ); follow-up of prior benign breast disease $(n=152)$; mammographic abnormalities detected through the national breast cancer screening progtamme ( $n=144)$; family history of breast cancer $(n=234)$, patient's anxiety $(n=13)$; and other asymptomatic reasons $(n=83)$. These last 3 indications for tefertal were combined as "reassurance".

One patient was included twice as both visits concerned different indications in different breasts. There were 182 patients who underwent a prior mastectomy because of a history of breast cancer in whom the contralateral breast was investigated; in 23 other patients, only one breast was examined for orher reasons. So, 3835 breasts were examined in 2020 patients.

Table 4.1. Results of plyysical examitration + mammography and physical examination + mammograplyy + ultrasonography by malignancy for all 3835

Cases

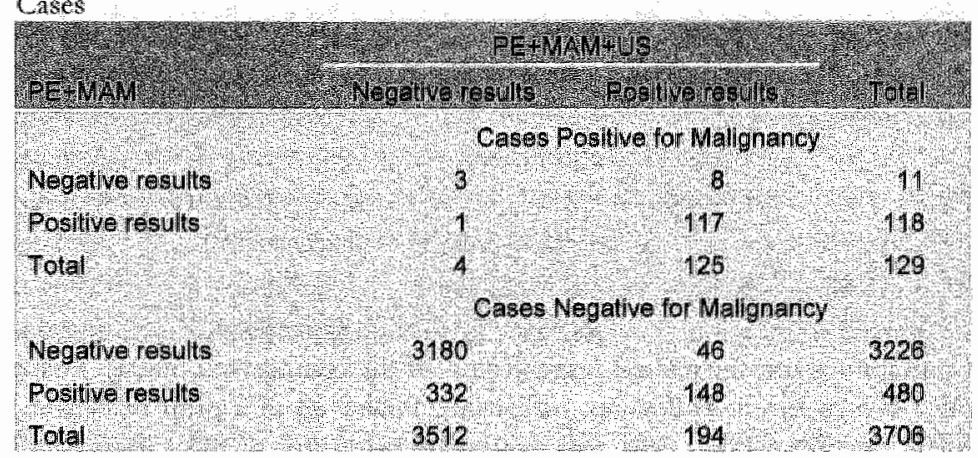

MAM, nammography; PE, physical examination; US, wiltrasonography 
After a follow-up of 12 months, 129 malignancies were found in 127 patients, leading to a prevalence of $6.3 \%(127 / 2020)$. Two patients had billateral breast cancer. Thirteen malignancies were carcinomas in situ only, and 116 were invasive carcinomas. In 123 cases, malignancies were found as a result of the diagnostic imaging described. Six malignancies werte detected after $3(n=1), 7(n=1)$, and $12(n=4)$ months of follow-up. In 3 cases, a malignancy was found during the radiological follow-up of benign callifications (1 after 3 months and 2 after 12 months). Two patients presented with a new palpable lesion at 7 and 12 months after the initial breast imaging in this study, which reported normal reading results. Finally, is 1 patient, yearly radiological follow-up of a prior breast malignancy led to the detection of a new lesion after 12 months.

\section{DLAGNOSTIC PERFORMANNEE}

Using a cutoff between benign and probably benign tesults, thus defining scores 3,4 and 5 as positive results and scores 1 and 2 as negative tesults, physical examination detected $69.0 \%$ of all malignancies $(89 / 129)$, mammography detected $82.9 \%(107 / 129)$, and ultrasonography detected $87.6 \%(113 / 129)$. The specificity reached $92.5 \%(3616 / 3910)$ for physical examination, 91.9\% (3405/3706) for mammography, and $25.5 \%(3556 / 3723)$ for ultrasonography.

Table 4.2. Results of diagnostic imaging tests of 8 extra cases of breast cancer detected by ultrasonography

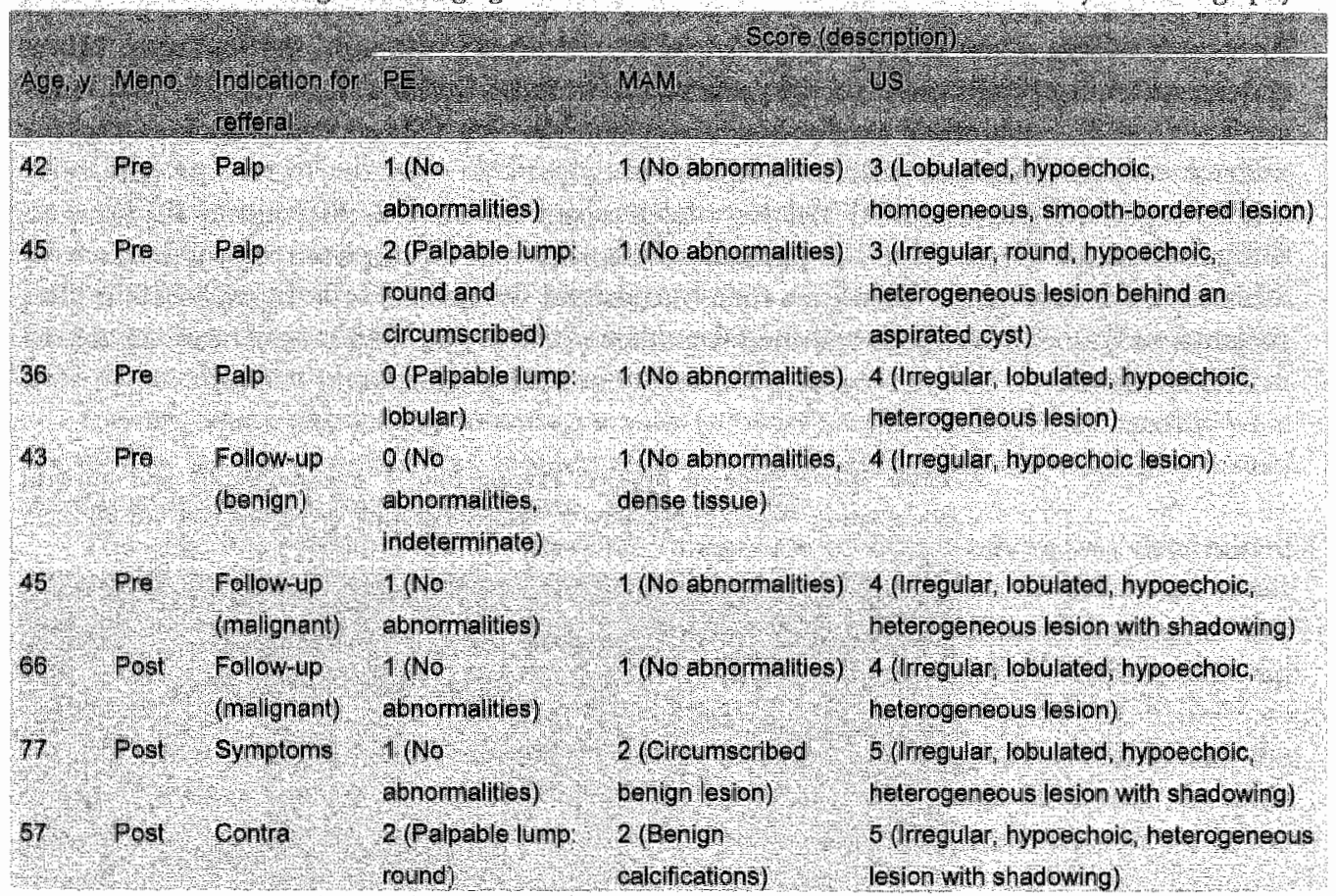

Contra, no renon for teferral (examination of the contralateral breast); Follow-up (benign), Follow-up of a prior benign lesion; Follow-nep (malignant), Follow-up of a prior malignant lesion; MAM, mammography; Meno, Menopausality; Palp, palpable breast mass; PE, physical examination; Post, postmenopausal; Pre, premenopausal; US, ultrasonogtaphy. 
Table 4.1 shows the test results of physical examination + mammography + ultrasonography and physical examination + mammogtaphy categarized by the absence or presence of breast cancer. For physical examination t mammogtaphy, the sensitivity was $91.5 \%(118 / 129)$, the specificity was $87.0 \%(3226 / 3706)$, the positive predictive value was $19.7 \%(118 /[118+480])$, and the negative predictive value was $99.7 \%$ $(3226 /[11+3226])$; for physical examination + mammography + ultrasonography the sensitivity was $96.9 \%(125 / 129)$, the specificity was $948 \%(3512 / 3706)$, the positive predictive value was $39.2 \%(125 /[125+194])$, and the negative predictive value was $99.9 \%$ $(3512 /[4+3512])$.

Breast ultrasonography detected 8 extra malignancies that were missed by the physical examination + mammogtaphy, A detailed description of these cases is given in table 4.2 . Furthermore, ultrasonography correctly downgraded 332 cases from a positive to a negative diagnosis (ie, from a suggested malignancy to no malignancy). On the contrary, there were 46 false-positive ultrasonography results, and in 1 case; ultrasonography incorrectly downgraded the imaging result to a negative diagnosis.

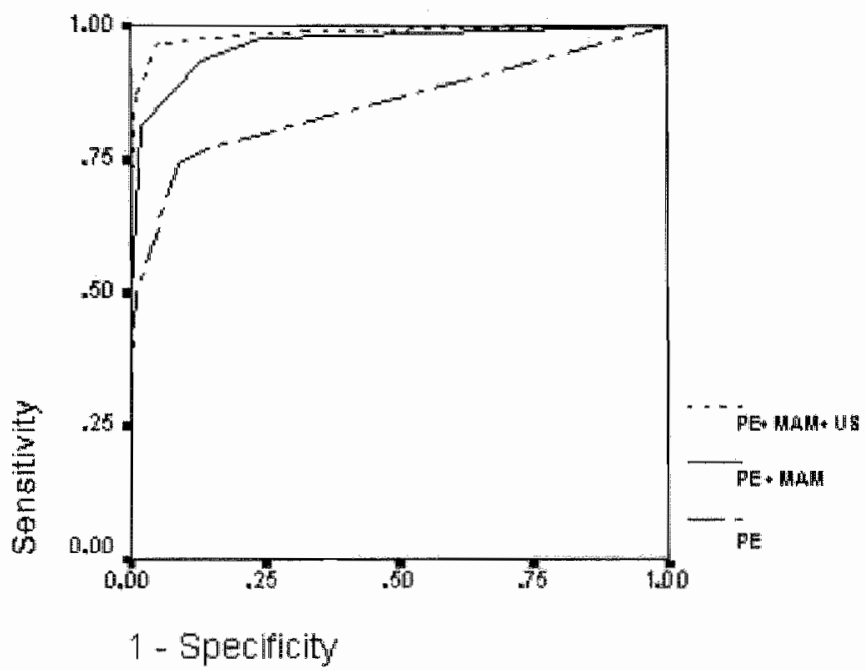

Figure 4.1. Receiver-operating characteristic curves for physical cxamination (PE) physical examination conbined with ditammography $(P E+M A M)$, and physical examination + manumography combined with ultrasonography (PE+MNM+US) for all 3835 cases. The arta under the curve for PE was 0.84 (95\% confidenee interval $[\mathrm{CM}, 0.79-0.8 \%)$ for PE+MAM, $0.95(95 \% \mathrm{CI}, 0.93-0.98)$; and for PE+MAM+US, 0.99 (95\% $\mathrm{Cl}, 0,97-0.997)$. The standard etrors were $0.03,0.01$, and 0.06 , respectively.

\section{ROC-CURVES}

Receiver-operating characteristic curves were constructed for the results of physical examination, physical examination + mammography and physical examination t mammography + ultrasonogtaphy for all 3835 cases (figure 4.1). Compating the AUCs, 
there was a significant increase in diagnostic performatice by the application of additional uitrasonography (AUC for physical examnation + mammography + ultrasonography vs physical examination + mammography, $0.99 \mathrm{vs} 0.95 ; \mathrm{p}=0.002$ ). Furthermore, the AUCs for physical examination + mammography and physical examinaton + maminography + ultrasonography were significantly different from the AUC for physical examination alone $(\mathrm{p}<0,001$ for both).

A total of 1228 patients were referted for the imaging of a single breast, and 792 were referred for the examination of both sides. Thus, of the 3835 breasts examined, breast imaging was done on referral in 2812 cases and as screening of the contralateral side in 1023 cases. In table 4.3 , the AUC of ROC curves for these groups shows that the additional diagnostic walue of ultrasonography was highest in the referred cases. In patients in whom breast imaging of the contralateral side was performed or in whom reassurance was the reason for referral, no additional diagnostic value was demonstrated for ultrasonography ( $p$-value not applicable because of small numbers).

Table 4.3. Areas under the ROC curves for physical examination + mammography and the final diagnosis (physical examination + mammography + ultrasonographys) for cases with and without a reason for teferral fot diagnostic breast imaging

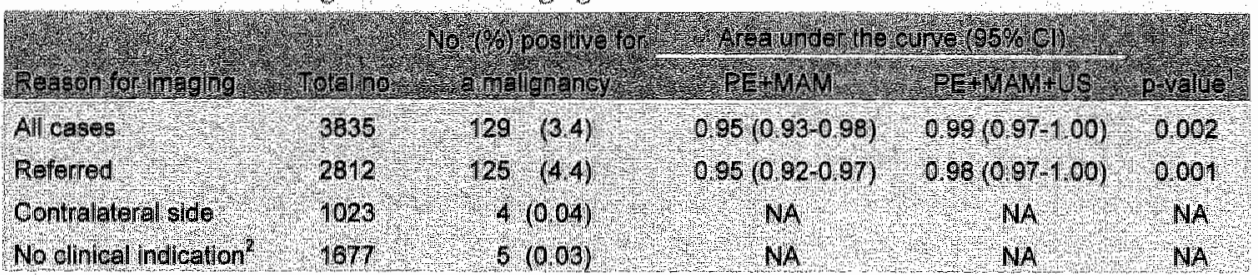

$\mathrm{CI}$, confidence interval; MAM, mammography; NA, not applicable (too few malignancies in these groups); PE, physical examination; ROC, receiver-operating characteristic; US, ultrasonography 'p-value for $\mathbb{P E E}+$ MAM + US vs PE + MAM

zdefined as examination of contralateral breasts and cases of teferral for "reassurance".

\section{INDICATIONS FOR BREAST ULTRASONOGRAPHY}

To study subgroups of patients who benefit most from additional ultrasonography, the diagnostic value was calculated through $\mathrm{ROC}$ curves by indication for referral and age categonies (table 4.4). The diagnostic value improved significantly in patients with palpable breast lumps $(p=0.004)$, most pronounced for those 50 years or younger, and in patents referred through the national breast cancer screening progtamme (women $>50$ years, $p=0.05$ )

In the patients referred for palpable himps, ultrasonography correctly downgraded 133 positive physical examination + manmography results. Furthermore, wittasonography detected 3 new malignancies at the cost of 11 false-positive results.

Of the 147 cases referted by the national breast cancer screening programme, the results of 40 manmograms + physical examinations wete negative. Ultrasonography did not detect new malignancies in this group, but cortectly downgraded 29 positive mamnograms to a negative diagnosis. 
Table 4.4. Areas under the ROC curves for and the final diagnosis (physical examination + nammogumphy + ultrsonography) by indication for referral and age for 2812 cases

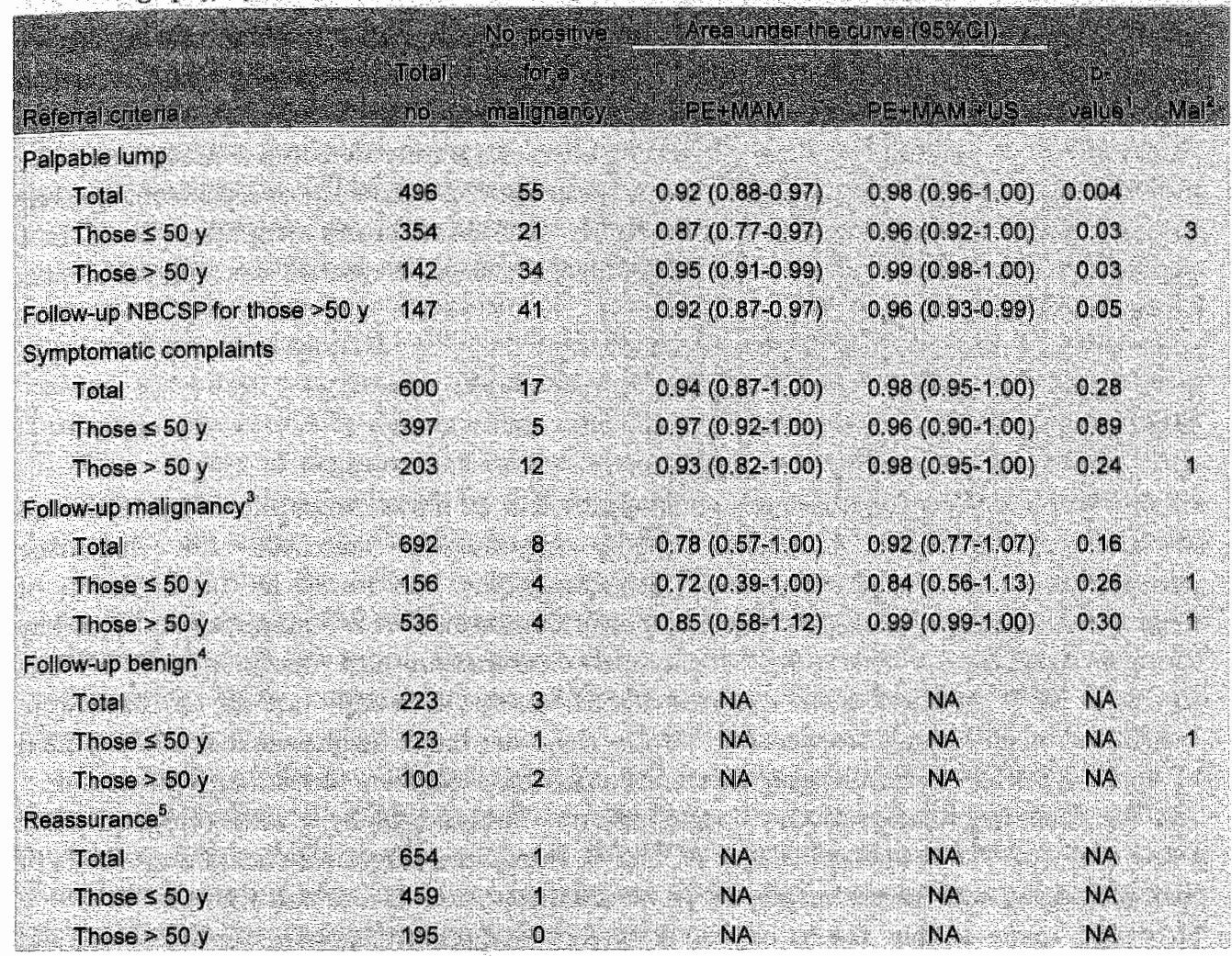

$\mathrm{CI}$, confidence interval; MAM, mammography; NA, not applicable (too few malignancies in these groups); NBCSP, national breast cancer screening programme; PE, physical examination; ROC; receiver-operating characteristic; US, ultrasonogtaphy.

tp-walue, for PE + MAM + US vs PE + MAM.

2malignancies detected onlly by breast ultrasonography (1 case was teferred for the contralateral brenst)

${ }^{3}$ Follow-up of a prior malignant lesion.

ffollow-up of a prior benign lesion.

Includes those with a famil history or a fear of breast cancer (asymptomatic patients).

Additional ultrasonography also increased the diagnostic value in patients referted for other symptoms, such as pain and nipple or skin abnotmalities $(p=0.28 ; 1$ new malignancy was found) and in patients referred for follow-up of a prior breast malignancy $(p=0.16 ; 2$ new malignancies were found), although the difference in AUC was not statistically significant.

In patients referred for follow-up of a prior benign abnormality, additional ultrasonography detected 1 extra malignancy and confirmed 2 malignant diagnoses by physical examination + mammography ( $\mathrm{p}$-value not applicable because of small numbers). 
Finally, among the 654 cases referred for reassurance, because of fear or a family history of breast cancer, ultrasonography missed the single malignancy in this group, which was detected by physical examination + mammography ( $p$-value not applicable because of small numbers). There were 12 alse-positive ultrasonography result, of which 4 wete also false-positive mammography results.

For the 8 patients in whom only breast ultrasonography detected malignancy, the indications for referral were palpable breast lumps $(n=3)$, follow-up of a prior malignancy $(n=2)$, follow -up of a prior benign abnormality $(n=1)$, and breast symptoms $(n=1)$. In 1 patient, the cancer was found by chance, while the reason for referral was a palpable mass on the contralateral side.

\section{DISCUSSION}

In this outpatient population, systematic application of ultrasonography as an adjunct to physical examination and mammography significantly increased the diagnostic performance. The diagnostic gain of ultrasonography was found in the detection of 8 extra malignancies that were missed by physical examination and mammography and by the downgrading of false-positive physcial examination and mammography results $(n=332)$. Most of these were cysts or fibroadenoma, although not all of them were confirmed by pathologic features. $2,4,17,18$ On the other hand, diagnostic loss was reflected by 46 false-positive ultrasonographic results and 1 false-negative ultrasonographic result.

The final diagnosis of physical examination + mammography + ultrasonography had a sensitivity of $96.9 \%$ and specificity of $94.8 \%$. Integrated diagnoses combining results of mammography and ultrasonography have been reported in several studies. 2, 5, 7.12, 19 However, many studies fail to explain how this integrated diagnosis was obtained, and only few studies describe consecutive sets of patients. Comparison with our data should, therefore, be done carefully, but lower sensitivities and slightly higher specificities are reported.5,12, 19 This may be explained by their study design, in which ultrasonography was only applied on clinical indication. The prevalence of breast cancer in this population was $6.3 \%$, and is consistent with the results of these other studies $5,12,19$ in consecutive patients, reporting prevalences of $5.0 \%$ to $7.1 \%$

Despite the overall increase in diagnostic yield by systematic application, breast ultrasonogtaphy should be restricted to subgroups of patients who benefit most to reduce the costs, time needed for diagnostic examinations and harmful consequences of unnecessary examinations. According to out results the application of breast ultrasonography was most beneficial to patients referred for palpable breast lumps and patients with an abnomal national breast cancer screening mammography result. Applying these criteria to our population, ultrasonography would be indicated in $30.4 \%$ (61.4/2020) of patients referred for diagnostic breast imaging.

In the literature, the presence of a palpable mass in young women is a well-described indication for breast ultrasonography as an inirial diagnostic imaging test $3,4,18,26$ or as an adjunct to mammography. ${ }^{2,} 1 \%$ While most studies are referring to women 35 years and younger, our results are applicable to women 50 years and younger. Ultrasonography detected additional malignancies in 8 patients, of whom 3 wete referred because of a 
palpable mass and 1 was referred because of a palpable lump at physical examination. According to dinical guidelines, all palpable masses should undergo cytological investigation, which would have detected these malignancies as well However, ultrasonography still has an important diagnostic tole in these cases by completing the triple assessment, consisting of physical examination, radiological imaging and cytological diagnosis, which facilitates treatment planning. Because a proportion of the cytological investigation results will be indeterminate, wltrasonography results will be valuable.

To our knowledge, an abnormal national breast cancer screening programme mammography result has not been reported in the literature as indication for additional ultrasonography; however palpable or non-palpable non-conclusive mammogtaplyy abnomalities are discussed. $12,18,19,21,22$ In the patients referted from the national breast cancer screening programme, utrasonography reduced the number of false-positive mammography results by downgrading a quarter of all cases positive for a malignancy.

The increase in diagnostic value was not significant in patients referted with breast. symptoms or in those referred for follow-up of a prior malignancy. Remarkably, in this last group, the largest absolute increase in AUC was found, but the few cases positive for a malignancy and the relatively high standard ertors prevent us from drawing any definitive conclusions. ${ }^{16}$ Furthermore, in the groups of patients teferted for follow-up of a previous benign lesion or for reassurance, there were too few malignant cases for constructing ROC curves and no additional value for ultrasonography could be demonstrated.

The role of breast ultrasonography in screening asymptomatic patients is a controversial one, $2,4,23,24$ Our data show 5 malignancies in the patients without a clinical indication (table 4.3), of which 4 were found it contralateral breasts and only 1 was found in the group of referrals for reassurance (table 4.4), suggesting a poor diagnostic yield of breast imaging as a whole in these patients.

An alternative way for recoding indeterminate test results for analysis would be through the comparison of likelihood ratios for each level of suggestion of malignancy, ${ }^{25}$ and recoding them as the level that is most alike. Doing so, indeterminate mammography results would be recoded as negative findings, but our final conclusions would be similar." However, we believe that our applied method of recoding approaches clinical practice best, because indeterminate mammography results will always lead to additional testing. Furthermore, the breast imaging teporting and data system lexicon also treats indeterminate mammography results as positive. ${ }^{13}$

Recoding undeterminate physical examinations as positive results, als done fo: manmography and ultrasonography, also would not affect the AUC (0.83 vs 0.84) or change our conclusions.

Many diagnostic studies use 1 end point for the follow-up of patients included over several months or years. As a consequence, these studies are biased in their definition of the criterion standard because the length of follow-up is different for each case. Therefore, in the present study, an equal follow-up of 12 months was used for all patients, extended for 2 months for administrative transactions of results at the end of this period. The period of 12 months was chosen to minimize the chance of detection of newly developed (interval) cancers and to maximize the chance of detection of the malignancies present. Nevertheless, when including the total range of follow-up from October 01,1999 
to October 01,2001 (median, 19 months; range, $14-24$ months), no additional falsenegative imaging results were found. Despite the passive nature of the follow-up, we believe that the registration system used covered all pathologic conditions avaliable for the wliole study population.

The indications for breast imaging in this study were defined by the referring physicians, and symptoms could not always be confirmed by the specialist conducting the physical examination (eg, the palpation of a palpable lump). Because such situations reflect clinical practice, we decided to use the specified reason for teferral in these cases wher than our findings at physical examination. Associated is the fact that additional indications for ultrasonogtaphy could be defined based on the results from physical examination or from mammography. However, by applying the set of criteria in daily practice, the advice to perform or withhold additional ultrasonography could be given at the stage of referral for breast imaging. By doing so, the planning of breast imaging could be optimized and the number of redundant ultrasonographic examinations reduced. Additional research will be needed to determine the cost-effectiveness of the application of breast ultrasonography in these specified groups of patients.

In conclusion, the systematic application of additional breast ultrasonography improved the diagnostic performance in this population. Although the overall diagnostic yield improved, the number of unnecessary examinations can be reduced by restricting breast ultrasonography mainly to patients with palpable breast lumps and patients referred with abnormal screening mammography results. The implementation of these evidence-based indications in clinical practice is expected to lead to more efficient and effective use of bieast ultrasonogtaphy. 


\section{REFERENCES}

1. Hatris, JR, er al, Breast cancer(1). N Engl J Med, 1992. 327" 319-28.

2. Smith, DN, Breast taltasound. Radiol Clin North Am, 2001. 39(3): 485-97.

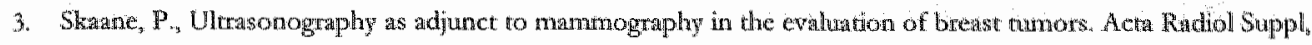
1999 420:1.47.

4. Jackson, V.P., Reynolds $\mathbb{H}$ E, and Hawes D.R., Sonography of the breast. Semin Ultirsound CT MR, 1996. $17(5): 460-75$

5. Flobloc, K., er al., Diagnostic value of radiological breast imaging in a non-screening population. Int J Cancer, 2001. 92(4): 61.6-8.

6. Hillman, B. ., Nex imaging technology and cost contanment AJR An J Roentgenol, 1994, 162(3): $503-6$.

7. Hardy, J.R., et al, How many tests are required in the diagnosis of palpable breast abnomalicies? Cha Oncol (R Coll Radiol), $1990.2(3): 148.52$.

8. Moss, H.A. et al., How reliable is modem brenst imaging in differentiating benign from malignant breast lesions in the symptomatic population Clin Radiol, 1999. 54(10):676-82.

9. Ozdemir, A., et al., TH-201 scintignaphy, mammography and ultrasonography in the exaluation of patpable and norpalpable breast lesions: a correlative study. Eur J Radiol, 1997. 24(2): 145-54.

10. Ruhland, $\mathbb{F}_{*}$ et al., [Diagnostic value of mammography and breast ultrasound for clinically occult lesions of the breast]. Geburtsh [rauenheilh, 2000. 60: 104-10.

11. Skaane, $P_{*}$ Engedal $K$, and Skjennald A., Interobserver varation it the interptetation of breast imaging. Comparison of mamnography, ultrasonography, and both combined in the interpretation of palpable noncalcified breast masses. Acta Radiol, 1997. 38(4 Pt 1): 497-502.

12. Zonderland, H.M. et al. Diagnosis of breast cancer: contribution of US ats an adjunct to mammography. Radiology, 1999. 213(2): 413-22.

13. American College of Radiology, Illustrted Breast Imaging Reporting and Data System (IIlustrated BILRADS). 1998, American Colliegre of Radiolgy. 179-81.

14. Meridelson, E.B., Berg W.A., and Merritr C.R., Towards a standardized breast ultrasound lexicon, BI-RADS: ultrasound. Semin Roentgenol, 2001. 36(3):217-25

15. Hanlley, J.A. and MCNeil B.]., The meaning and use of the area under a receiver operating characteristic (ROC) curye. Radiology, 1982 . 143(1):29-36

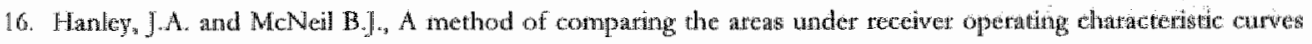
derved from the same cases. Radiology, 1983. 148(3): 839-43.

17. Skatac, P., The additional walue of US to mammogaphy in the diagnosis of breast cancer. A prospective study. Acta Radiol, 1999. 40(3): 486-901.

18. Mendelson, E.B. and Tobin C.E, Critical partways in using breast US. Radiographics, 1995. 15(4): 935 .45.

19. Dujim, L. E, et al., Senutivity, specificity and predictive values of breast imaging in the dietection of cancer. Br I Cancer, $1997.76(3): 377.81$.

20. Herd, T.C. and Edge S.B, Breast cancer imaging. Surg Oncol Clin N Am, 1999, 8(1): 1-15.

21. Houssami, $N$, and lowig $\mathbb{L}$. Lilkelihood ratios for clinical examination, rmmmography, whatound and fine needle biopsy in women with breast problems. The Breast, 1998. 7:85.9.

22. Oord van, J.C., et al, The value of ututasound mammography in palpalble breast masses Rofo Portschr Geb Rontgenstr Weuen Bildgeb Verfahr, $1991.155(1): 63-6$.

23. Kolb, T.M. Lichy $\mathrm{J}$, and Newhouse J.H., Occult cancer in women with derne breasts: detection with screening US-diagnostic yield and tumor characteristics. Radiology, 1998. 207(1): 191.9.

24. Kopans D.B., Breast-Cancer screening with ultrasonography. Lancer, 1999, 3549196): $2096-7$.

25. Sacket, D... er al, Clinical Epidemology: A Basic Science for Clinical Medicinc. 2nd ed. ed. 1991, philadelphin. Pa: Lippincont Willams Wilkins. 


\title{
CHAPTER
}

V

\section{Interexamination variation of whole breast ultrasonography}

\author{
A.M. Bosch \\ A.G.H. Kessels \\ G.L. Beers \\ K..C.G. Vranken \\ A.C. Borsthp \\ M.F. von Meyerfeldt \\ J.M.A. wan Engedsowen
}

The British Joumal of Radiology; $752003: 328-331$ 


\begin{abstract}
The purpose of this study is to determine the interexamination agreement of ultusonogtaphy of the breasts. This includes the complete process of performing whole breast ulrasonography and interpreting the dynamic scanning and the static images by one person. Methods - In a prospective study, 58 patients with a clinical indication for mammography underwent ultrasonography examination of both breasts by three independent sonographers. The sonographers had full knowledge of the physical and mammographical findings. Histollogy and 12 months follow-up were used as the reference standard. Interobserver variability for both mammography and breast ultrasonography was measured using linearly weighted kappa statistics. Receiver operating characteristic curves were constructed to compare the diagnostic performance of the observers. Results - The interexamination agreement for the score of the probability of malignancy after mammogtaphy was substantial (kappas ranged from 0.63 to 0.65 ). The interexamination agreement for the final score of the probability of malignancy after mammography and ultrasonography was slightly better (kappas ranged from 0.72 to 0.75 ). The area under the receiver operating characteristic curves after mammography and ultrasonography examination tanged from 0.97 to 0.98 . Conclusion - Ultrasonography examination of the whole breast shows a substantial interexamination agreement. Ultrasonography of the breast adds consistency to mammography and physical examination.
\end{abstract}




\section{INTRODUCTION}

Ultrasonography (US) has become an established diagnostic adjunct to mammography in the evaluation of breast abnormalities. The main goals of US of the breast are to differentiate cystic from solid lesions, benign solid lesions from malignant solid lesions ${ }^{\text {t.t. }}$, and to clarify difficulties in mammographic intexpretation. An important drawback of US is operator-dependency. The interobserver variation of reading breast US hardcopy images has been assessed in previous studies ${ }^{6-11}$. However, these studies are not representative for the interexamination variation of the complete procedure. The selection of the static images, used in the previous studies, is influenced by the ability of the sonographer to recognize breast abnormalities during dynamic scanning: It is cleat that the true interexamination variation consists of more than just the differences in reading hardcopy images. Therefore the true reproducibility may be lower than suggested in the previous reports. To our knowledge, the interexamination variation of the complete process of performing the US examination and interpreting the dynamic scanning and the static images by the same person has not been previously assessed.

The aim of this study was to assess the interexamination variation of the complete US procedure.

\section{METHODS}

The Medical Ethics Committee of the University Hospital Maastricht apptoved this prospective study. It was part of a larger project in which all patients referred for mammography underwent an additional US examination of the breasts to assess the added value of whole breast US for vatious indications.

Between March and August 2000, patients were selected from those referred for mammography to the Department of Radiology of the University Hospital Maastricht. After giving informed consent, the parients consecutively underwent a standard physical examination of the breasts, mammography and three US examinations of the breasts by three different sonographers.

Selection was made to increase the number of abmormalities at breast US and to obtain a more even distribution of the different US results compared to the normal population. Patients were selected when they were referred by a surgeon, or when the request form for mammography stated the presence of a palpable lump or local pain, or an increased risk of breast cancet.

A resident with special interest in senology performed physical examination in the Department of Radiology. The presence of a mass, as well as its location, consistency, size and adherence to the surrounding tissues were recorded. A final probability of malignancy was assigned in a 5-point scale: no abnormalities; benign finding; probably benign finding; maiignancy suspected; and malignant finding.

Mammography was performed using craniocaudal and mediolateral oblique projections (Bennet Contour Plus, Oldelft-Benelux, Delft, The Netherlands and Kodak Min-R film screen combination). When indicated, coned-down views, magnification views 
or views in a third direction were added. Mammography was interpreted by a radiologist with special interest and experience in breast imaging. The mammography images were scored for the density of the breast tissue (4-point scale as described in the BI-RADS reporting system ${ }^{2}$ ), the presence of masses, the localizarion, size, type of the masses, and presence of microcalcifications. Ot the basis of this evaluation the probability of malignancy was scored on a 5-point scale (based on the BI-RADS lexicon for mammography) ${ }^{12}$ : (1)no abnomalities; (2)benign finding; (3)probably benign funding; (4)malignancy suspected; and (5)malignant finding.

US examination was carried out using an ATL ultrasonography scanner (HDI 5000 , ATL, Bothell-Washington, USA) and a $12-5 \mathrm{MHz}$ linear array transducer. There was no time limit for performing the whole breast US examination. The three sonographers were two experienced radiologists and one resident. The radiologists had 3 years and over 5 years of experience, respectively. The radiologist with over 5 years of experience was also participating in the National Breast Cancer Screening Progtamme. The resident had carried out 500 breast US examinations prior to this study. Each sonographer was informed about the results of the physical examination and had access to the mammogram and its report. The US exams were performed in random order by the three sonographers while they were blinded to the US results of their colleagues. The presence of any lesion was noted by each sonographer, as well as its location, size, margins, posterior echoes and echogenicity. The US diagnosis and the final probability of malignancy was scored on a 5-point scale (based on the BI-RADS-score under development for ultrasonography ${ }^{13}$ : no abnormalities; benign finding; probably benign finding; malignancy suspected; and malignant finding) were recorded.

In order to determine whether US adds consistency to mammography and physical examination, the three sonographers independently interpreted the mammograms with knowledge of the physical information about the breasts. This assessment was made three months after the initial diagnostic procedure. The same items as described above wete scored.

Finally we studied the interexamination agreement in subgroups of patients based on: (1)the presence and absence of a palpable mass; (2)the presence and absence of a lesion on mammography; (3) the density of the breast on mammography $(75 \%$ dens breasts compared with less then $50 \%$ dense breasts); and (4) the presence or absence of an accepted indication for breast US. Breast US was considered indicated when there was a palpable lesion, and/or a mammographic lesion with a BI-RADS-Score of 3 or higher and/or non-conclusive mammography because of high density breasts.

The final diagnosis for each breast was established by histology and follow-up of 12 months. Pathology results were retrieved from the hospital department of pathology and the Dutch Network and National Database for Pathology (PALGA). As all national hospital pathology departments are linked to this database, complete coverage of the study population was assured, including patients who were diagnosed elsewhere. The final diagnoses were divided in: (1) no abnormalities; (2) benign cystric findings; (3) benign solid lesions; and (4) malignant findings. 


\section{STATISTCAL ANALYSIS}

To measure the extent of agreenent between the examinations linearly weighted kappa values were calculated. The kappa staristic measures the proportion of decisions in which observers agree while accounting for the possibility of agreement based on chance. Perfect agreement results in a kappa value of 1.0 and a kappa value of 0 indicates the level of agreement expected based on chance alone. Landis ${ }^{14}$ indicated kappa values of 0.2 or less as slight agreement, $0.21-0.40$ as fair, $0.41-0.60$ as moderate, $0.61-0.80$ as substantial, and $0.81-1.00$ indicates almost perfect agreement between observers. Other researchers consider kappa values of 0.50 or less as poor and values of 0.75 or more as excellent reproducibility ${ }^{15}$. Differences in kappas between the mammographic and US results were tested using the jack-knife method ${ }^{16}$.

Diagnostic performance was evaluated using the fiwe levels of suspicion categontes in receiver operating characteristic ( $R O C$-) analysis. $R O C$ analysis was carried out for the combined result of the physical examination, mammography and US of ench sonographer. The area under the ROC curves (AUC-ROC) was used as a measure of diagnostic performance. The differences between the areas under two $R O C$-curves were compared, taking into account that both curves were derived from the same cases ${ }^{17}$.

A p-value of $\leq 0.05$ was considered as statistically significant.

\section{RESULTS}

Between March 2000 and August 2000, fifty-eight women (113 breasts, three patients post unilateral mastectomy) were included in this study. The mean age of the women was 52.6 years (range $18.4-86.9$ years). The indication for mammography was a palpable lesion in 21 patients ( 22 breasts), other local breast complaints such as pain in 10 women (10 breasts), a BI-RADS-score of 3 or mote on the mammograms of the national breast screening progtamme in 16 patients (16 breasts), follow-up of malignant breast disease in 7 patients ( 12 breasts) and a high risk of breast cancer because of a positive family history in 4 ( 8 breasts). The remaining 45 breasts wete normal asymptomatic contra lateral breasts.

Table 5.1. Kappa scores and $95 \%$ confidence intervat of the 5 point scalle of probability of malignancy by mammogtaply and US for three observers

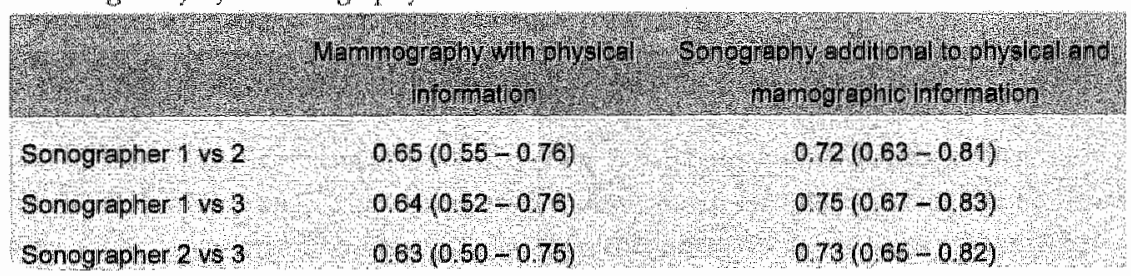

Sixty-eight breasts contained one or more lesions (60\%), out of which 11 were malignant. The mean radiological size of the lesions was $14 \mathrm{~mm}$. The mean histologicall size of the lesions was $15 \mathrm{~mm}$. Notmal or benign lesions were confirmed by histology in 13 cases, by repeated mammography in 27 cases and by a follow-up of 12 months in 62 cases. 
The interexamination agreement (kappa value) between the three sonographers in diagnosing the probability of malignancy for the US examination of the breasts ranged from 0.72 to 0.75 (all three with a standard deviation (sd) of 0.04) (table 5.1). The interobserver agreement for reading the mammography images of the same patients, and by the same observers ranged from 0.63 to 0.65 ( $\mathrm{sd}=0.06$ ). The total consistency (US with physical and mammographic information) increased compared to physical and mammographic information only. These differences were statistically significant for sonographer 2 and $3(\mathrm{p}=0.008)$.

Excluding the normal breasts did not affect the mammographic interexamination agreement (mean kxppa value $0.545, \mathrm{sd}=0.077$ ). The US interexamination agreement decreased slightly (mean kappa value $=0.651, \mathrm{sd}=0.065$ ).

For the subgroups based on clinical information the mean kappas of the three sonographers were calculated (table 5.2). There was a significant difference in kappa value for the subgroups based on the density of the breast on mammography.

As an index for the diagnostic performance, $\mathrm{ROC}$-curves of each sonographer were constructed (figure 5.1). The AUC-ROC-curves for the three sonographers did not differ significantly.

Table 5.2. Mean linearly weighted kappa scores of the 5-point scale of probabiliry of malignancy after US and the difference within the subgroups

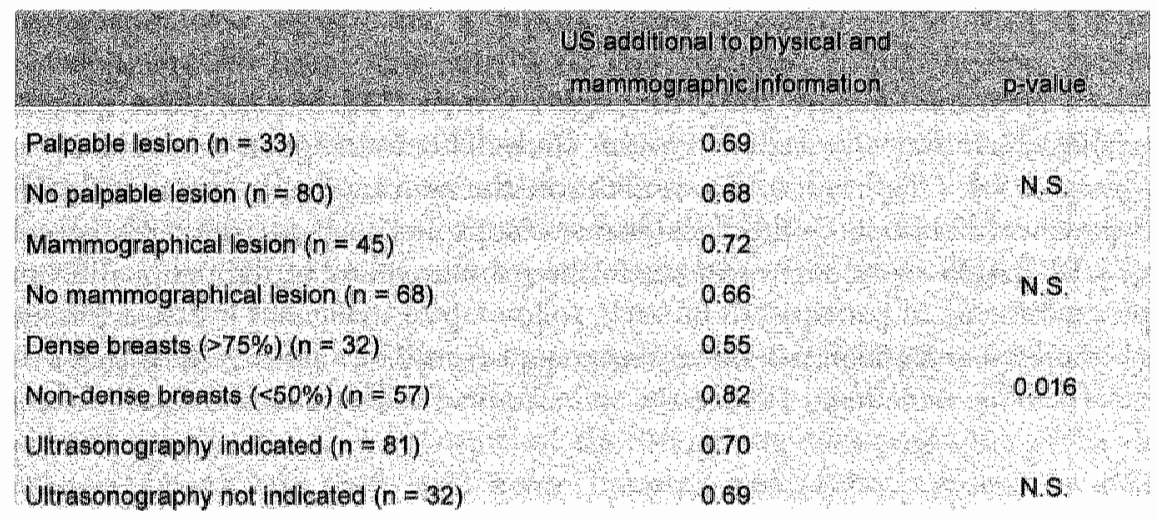

US, ultrasonography

\section{Discussion}

US examination of the whole breast with prior knowledge of physical and mammographic findings, shows substantial interexamination agreement (kappa value $0.72-0.75$ ) and adds consistency to the interpretation of the combined physical and mammographic examination (kappa value $0.63-0.65$ ).

Studies examining the total interexamination variability of whole breast ultrasonography examination, being the US scanning procedure combined with the interptetation of the images are, to our knowledge, not reported in the literature. For 


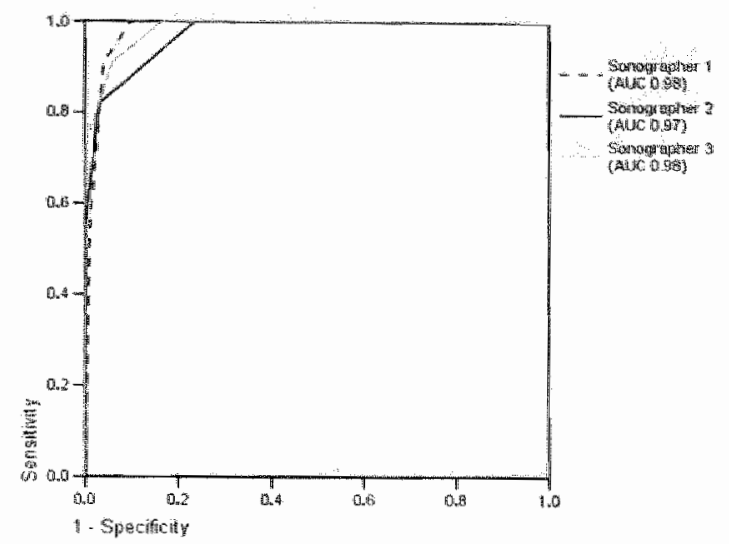

Figure 5.1. Recerver operating characteristic (ROC)curves of the diagnostic accuracy of breast ultrasound by thee sonographers. berween brackets aren under de ROC-curves).

consistency in reading breast US images alone, the kappa values range from 0.32 to $0.626,8,10,11$. In table 5.3 a comparison of some features of these studies is presented. Those studies determined interobserver examination retrospectively, from images with known lesions and a high cancer prevalence. These images have been obtained previously by a sonographer who was not the interpteting observer. "The observers retrospectively determined the characteristics of the lesions and the probability of malignancy. In our study, we not only determined the lesion characteristics, but also examined whether or not a lesion in a breast was detected. Two possible sources of disagreement: obtaining images and interpteting images were included in out study. In spite of the enhanced chance of disagreement by introducing the extra source, we obtained substantial agreement. An explanation might be the number of normal breasts (40\%) in our study compared to other studies (0\%). Excluding the normal breasts did not affect the mammographic interexamination agreement and decreased US interexamination agrement slightly.

Table 5.3. Jiterature on interobserver variability of breast sonography

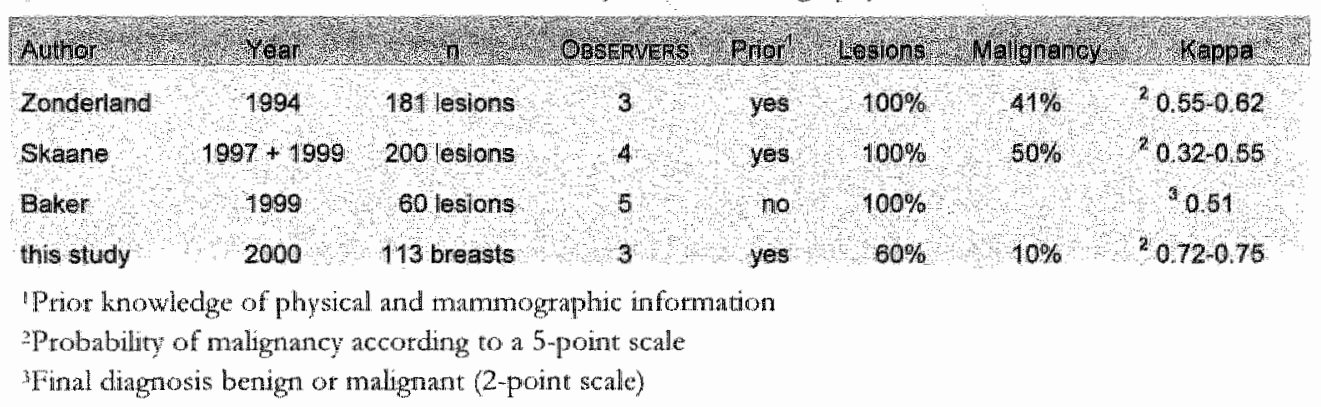


Uitrasonography examination of the breasts was performed as an adjunct to physical and maminographic findings. This is current policy and our daily practice and for this reason we decided to test the interexamination consistency in this context. At the time of the US examination the mammogtam and its results assessed by the attending radiologist were available to all three sonographers, creating the same conditions for the three sonographers. The availability of both the physical and mammographic information cannot be the cause of the higher agreement, because this information was also available in Zonderland"s and Skaane's study. This justifies the Dutch daily practice in which the reviewing radiologist is also the assessing radiologist.

Despite the differences in experience of the three sonographers the kappa values did not differ significantly between the three sonographers. The resident sonographer seems to have reached the required breast US experience plateau after 500 US.

Except for the 24 breasts for which we had a pathological diagnosis and the 27 cases, which underwent radiological follow-up examination, the diagnosis after a follow-up period of 12 months was considered as a reference test $(n=62)$. No false-negatives were found in this group, but the observation period of 12 months is short. However, our main goal was to study the interexamination agreement and not the diagnostic accuracy.

Table 5.2, showing kappa values for the subgroups, includes no significant difference within the sulbgroups, except for the dense/non-dense breast tissue group. Non-dense breasts showed high interobserver agreement on the mammography findings and therefore after US an increased interexamination agreement. Dense breasts often yield non-conclusive manmograms. US might be expected to increase the sensitivity and diagnostic accuracy of the radiological imaging ${ }^{2},{ }^{3}$. Our results showed a substantially lower agreement after US in the group of patients with dense breasts on the mammography.

In conclusion, The interexamination agreement for whole breast ultrasonography is substantial when this examination is performed as adjunct to physical examination and mammography. 


\section{REFERENCES}

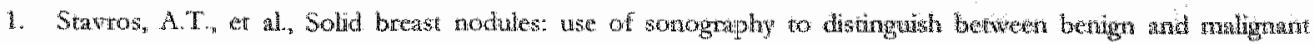
lesions. Radiology. $1995.196(1): 123-34$

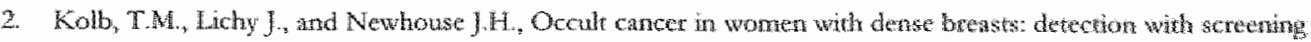
US- diagnostic yield and numor chatricteristics. Radiology, 1998, 207(1), 19149.

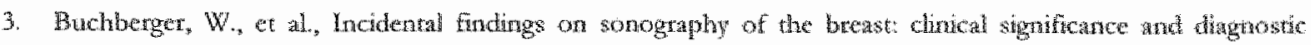
workup. AIR Am ) Roentgenol, 1999. 173(4):921-7.

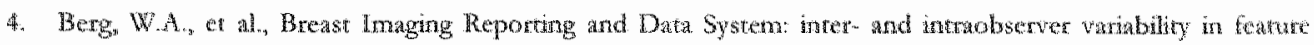
andysis and final assessment. Am J Roentgenol, 2000. 174(6): $1769 \% 7$.

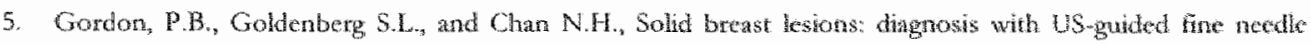
aspiration biopsy. Radiology, 1993. 189(2): 573-80.

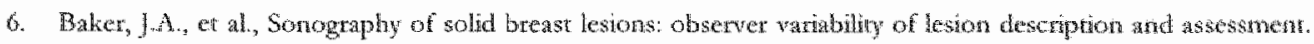
Am J Roentgenol, 1999.172(6): 1621-5.

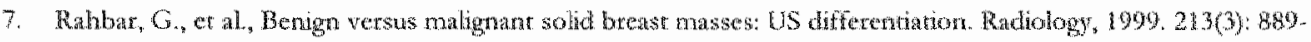
94.

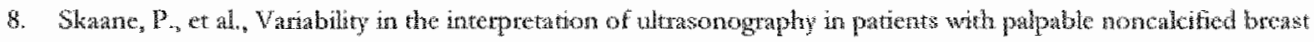
thumors. Actr Radiol, 1999. 40(2): 169-75.

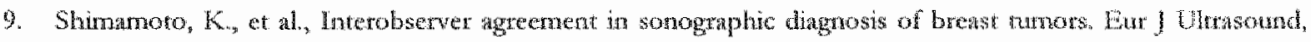
$1998.8(1): 25-31$.

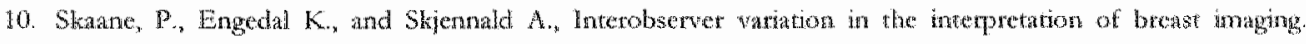
Comparison of mamamography, ultrasonography, and both combined in the interptetation of pubatble nomcalcified breast masses. Acta Radiol, 1997. 384 Pr 1): 497-502.

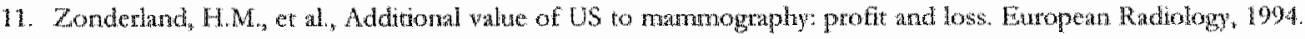
$4: 511 \%$

12. American College of Radiology, Mustrated Breast Imaging Reporting and Data System (Mhastrated BH-RADS3. 1998, American College of Radiolgy. $179-81$

13. Mendelson, E.B., Berg W.A., and Merrit C.R., Towatd standardized brenst ulrasound lewicon, ME RADS: altrasound. Semin Roentgenol, 2004. 36(3): 217-25.

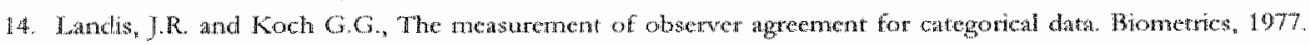
$33(1): 159-74$

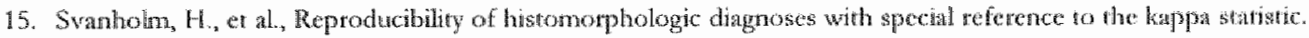
APML, 1989. 97(8):689.98.

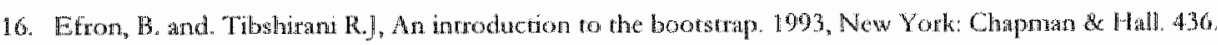

17. Hanley, J A and MCNeil BJ., A method of comparing the areas nder receiver enperaing chatracterstic curves derived from the same cases. Radiology, 1983. 148(3): 839-43. 


\section{CHAPTER}

VI

Additional pre-operative diagnostic analysis for a palpable breast lesion: the role of the triple diagnostic test and the histological core needle biopsy 
ABSTRACr - Since the introduction of the histological core needle biopsy for patients with a questionable breast mass, the role of fine needle aspiration cytology as part of the triple diagnostic test (physical examination, imaging and fine needle aspiration cytology) has been under debate. The aim of the present study was to evaluate the pre-operative diagnostic performance of the triple diagnostic test, and the additional value of the histological core needle biopsy of palpable breast lesions in an outpatient population. Methods - From October 1999 till August 2000, 2020 consecurive patients referred for mammography were prospectively followed during their diagnostic assessment. Suspected palpable lesions underwent fine needle aspiration cytology as part of the triple diagnostic test. A non-conclusive triple diagnostic test was a reason to perform a histological core needle biopsy. The results of excisionall biopsy and one year follow-up were used as the reference standard. The performance of the diagnostic modalities was described in terms of sensitivity and specificity, diagnostic odds ratio, and area under the receiver operating characteristic curves. Results - Out of 2020 patients 241 palpable breast lesions underwent fine needle aspiration cytology. Additional histological core needle biopsy was petformed in 70 cases. Rates of non-conclusive findings for fine needle aspiration cytology, triple diagnostic test, and histological core needle biopsy were $0.17,0.03$, and 0.06 , respectively. The areas under the receiver operading characteristic curves were 0.922 , 0.973 and 0.988 , respectively. Conclusion - The triple diagnostic test still has an important role to play in the diagnosis of palpable breast lesions. The histological core needle biopsy optimises the pre-operative diagnosis of a palpable breast lesion when the triple diagnostic test is non-conclusive. 


\section{INTRODUCTION}

The suspicion of breast cancer in a patient with a lump in the breast requires meticulous evaluation to reduce the level of diagnostic uncertainty and to allow optimal therapeutic decisions". Excisional biopsy of a lump that is assumed to be probably benign but eventually turns out to be malignant leads to an increased number of mastectomies when breast conservation would have been possible?

In an attempt to reduce the inappropriate number of excisional breast biopsies performed for palpable breast lesions, fune needle aspiration in combination with physical examination and imaging was introduced as the triple diagnostic test in the mid $1970 \mathrm{~s}^{3}$. Although on its own, fine needle aspiration cytology is not infalible, the combination with physical and tradiological examination is considered reliable enough for clinical decision-making. Another pre-operative diagnostic procedure is the core needle breast biopsy. This technique, introduced by Parker in 1990, allows pathologists to rely on histological rather than cytological aspects to determine the nature of the lesion ${ }^{4}$. Every diagnostic test has its limitations, which become evident in non-conclusive samples, and false-negative or false-positive findings. The question arises which test or combination of tests provides sufficient information to justify clinical decision-making about follow-up, surgical therapy and/or neo-adjuvant therapy in palpable breast lesions.

According to the surgical standards of the British National Health Service breast screening programme at least $70 \%$ (preferably more than $90 \%$ ) of breast cancers should have a pre-operative diagnosis by fine needle cytology or histological core needle biopsy.5.

The aims of the present study were (1) to evaluate the performance of the combined triple diagnostic test (physical examination, imaging and fine needle aspiration cytology) in women with a palpable breast lesion; (2)to determine the additional diagnostic value of the histological core needle biopsy in cases of uncertain test results, and (3)to find patientor imaging-based parameters which could render fine needle aspiration cytology unnecessary, in favour of histological core needlle biopsy.

\section{METHODS}

\section{PAthents}

During a 10 month period, all. consecurive patients referred to the department of radiology for diagnostic breast imaging underwent physical examination, mammography and ultrasonography as part of another diagnostic study, which is described elsewhere. From October 1999 till August 2000, 2020 patients (20 men and 2000 women) ranging in age from 16.8 to 90.3 (mean age 50.2 years), signed an informed consent form and underwent: physical examination and imaging (mammography as well as whole breast ultrasonography). The diagnostic modalities were applied in a fixed order. Results were known and tecorded before the next modality was started. There were 182 patients wirh breast amputations in whom the contralateral breast was investigated, and in 23 cases only one breast was examined for other reasons. Consequently, 3835 breasts were examined in 2020 patients. All suspicious or undefined palpable masses were included in this study. Physical 
examination and imaging excluded a proportion of the palpable lesions from further diagnostic tests because of a benign aspect (simple cysts or simple fibroadenomas).

\section{PHYSICAL FXAMNATYON}

A surgical resident with special interest in senology performed a physical examination of both breasts with the patient in upright and supine position. The patient's medical history was recorded, together with the sire and size of palpable lesions, nipple or skin abinormalities, discharge, and scars wete described in terms of location, size and association with pain and palpable lymph node status. Probability of malignancy was recorded on a five-point scale: no abnormalities, certainly benign, probably benign, suspicious for malignancy, and certainly malignant. Only well-circumscribed, mobile masses without any other sign of malignancy were assessed as benign. "Tumour fixation to the surroundings, tumour ulceration, skin tetraction, sanguineous nipple dischatge, or the presence of suspect palpable axillary lymph nodes were criteria for categorising the tumour as malignant. When a lump was difficult to classify because of scar tissue after previous treatment or mastopathic tissue, the examination was considered nonconclusive. Out of 2020 patients 519 palpable breast lesions were found.

\section{INAGING}

The mammography was performed using standard craniocaudal and mediolateral/oblique projections (Bennet Contour Plus Mammomat-2 unit, Siemens Oldelft-Benelux, Delft, The Netherlands and Kodak Min-R film screen combination, Rochester, New York). The attending radiologist indicated additional mammographic views and described and graded the mammogram. All radiologists had a special interest in breast imaging. All images were interpreted with full knowledge of the information from the history and physical examination. Whole breast ultrasonography was routinely performed in all patients in supine position using an ultrasound scanner (HDI5000, ATL, Bothell-Washington) with a 12-5 $\mathrm{MHz}$ handheld linear array transducer. The radiologist who interpreted the mammogram also performed and interpreted the ultrasound examination. The probability of malignancy at imaging was recorded using a five-point scale: no abnormalities, benign, probably benign, malignancy suspected and malignant (based on the BI-RADS lexicon)? Simple cysts and fibroadenomas were considered certainly benign lesions and no further diagnostic procedure was performed. Out of 519 palpable lesions imaging could determine a definitive benign result in 261 cases. These cases were simple cysts, fibroadenomas or normal breast tissue. For 258 palpable breast lesions further diagnostics wete indicated because of suspicious or uncertain results.

\section{FINE NEEDLE ASPRATION CYTOLOGY}

Fine needle aspiration cytology was performed in 241 of the 258 cases, as part of the ttiple diagnostic test for solid palpable breast lesions with a corresponding suspicious lesion at imaging. It was carried out with a 21 -gauge $40 \mathrm{~mm}$ needle (Tyco Healthcare, Switzerland Ltd, Wollerau, Switzerland) and a $10 \mathrm{ml}$ syringe. A smear was air-dried and stained by the May-Grunwald-Giemsa technique. The pathologist made his report with full knowledge of physical and radiological information. A cytological grade was assigned 
using a 5-point scale: normal/benign, probably benign, malignancy suspected/atypical findings, malignant, and non-conclusive ${ }^{8}$.

\section{TRIPLE DLAGNOSTIC TEST}

The results of the physical examination, amaging and the fine needle aspiration cytology in the triple diagnostic test were recoded dichotomously as benign or malignant. Benign included the no-abnormality, certainly benign and probably benign results. Malignant included the suspicious and certainly malignant tesults. The triple dingnostic test results were assessed on a four-point scale which is routinely used in daily practice (table 6.1). The results of the triple diagnostic test were considered to be certainly benign if the results of all modalities were benign or if only physical examination indicated a malignant result. The conclusion "certainly malignant" was drawn when all three diagnostic modalities indicated malignancy or at least fine needle aspiration cytology indicated malignancy and one of the two other diagnostic modalities also indicated malignancy. The conclusions "suspicious for malignancy" and "probably benign" were drawn as shown in table 6.1. In 7 cases both fine needle aspiration cytology and physical examination were non-conclusive, these 7 cases were non-conclusive in the triple diagnostic test as well. For a correct understanding of the results reported below, it is important to be aware of the sepatate results of the fine needle aspiration cytology and the triple diagnostic test.

Table 6.1. Recoding the separate tesults of plysical examination, imaging and fine needle aspiration cytology into a four-point scale for the triple diagnostic test (tn accordance with dally routine at our hospital).

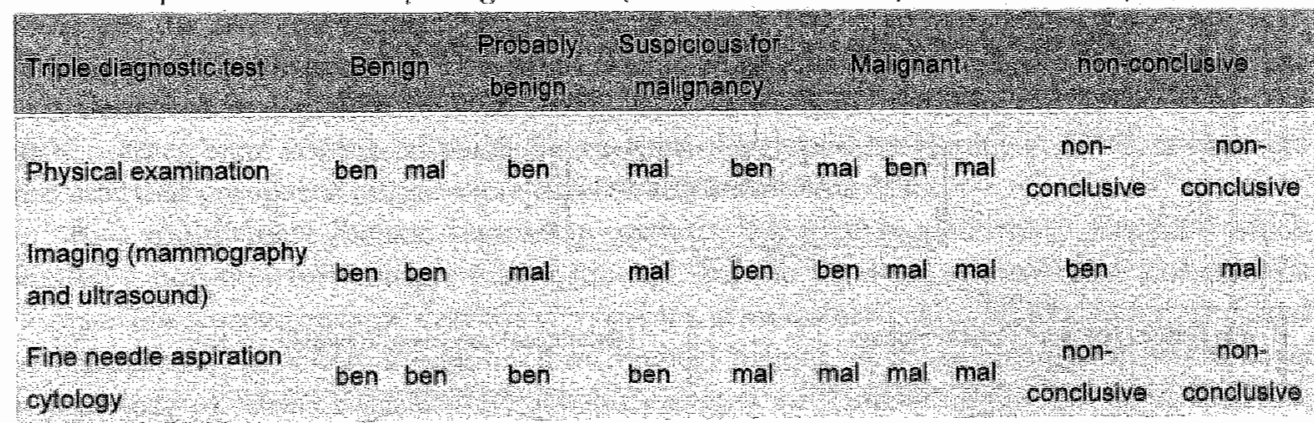

ben: benga, mal malignant

\section{HISTOLOGICAL CORE NEEDLE BIOPSY}

A histological core necdle biopsy was performed in 53 cases, in which there was no definitive benign or malignant diagnosis after the triple diagnostic test. In 17 cases, a histological core needle biopsy was performed immediately after imaging. The reasons to skip fine needle aspiration cytology were miscellaneous. This group was too small to be analysed further in the present study. Image-guided histological core needle biopsy took place after a small area of skin overlying the lump had been anaesthetised (with $5 \mathrm{cc}$ $1 \%$ lidocaine). A $2-4 \mathrm{~mm}$ incision was made with the point of a fine scalpel blade. A 14-gange x $10 \mathrm{~cm}$ biopsy needle (Pro-Mag 22, Medical Device Technologies Inc, Gainesville, Florida, USA) in an automatic biopsy instrument (Pro-Mag 2.2, Medical Device Technologies Inc, Gainesville, Florida, USA) was introduced and 5 to 9 cores of 
tissue were obtained. Following withdrawal of the needle, firm ptessure was applied to the breast for 3-5 minutes. The specimen was fixed in $10 \%$ buffered fomalin (Unifix, Klinipath, Duwen, the Netherlands) and paraffin sections were stained with Ehrlich"s acid Thaematoxylin and eosin. The histopathologist made his report with full knowledge of physical, radiological and earlier cytological information. Histological core needle biopsies wete classified as normal/benign, probably benign, malignancy suspected, malignant, or non-conchusive. If there was a high likelihood of sample error or if there were technical problems with the procedure, the result was classified as non-conclusive.

\section{STAINDARD OF REFERENCE}

Definitely benign or definitely malignant were determined by histology results from excisional biopsy and other surgical interventions during a follow-up period of 12 months. Histology results were retrieved from the hospital pathology department and the Dutch Network and National Database for Pathology (PALGA). As all national hospital pathology departments are linked to this database, complete coverage of the study population was assured, including patients who were subsequently diagnosed elsewhere. The histological diagnoses were divided into two categories: normal or benign breast disease (including atypical hyperplasia and LCIS), and malignancy (including carcinoma in situ and invasive carcinoma (with or without in situ carcinoma)).

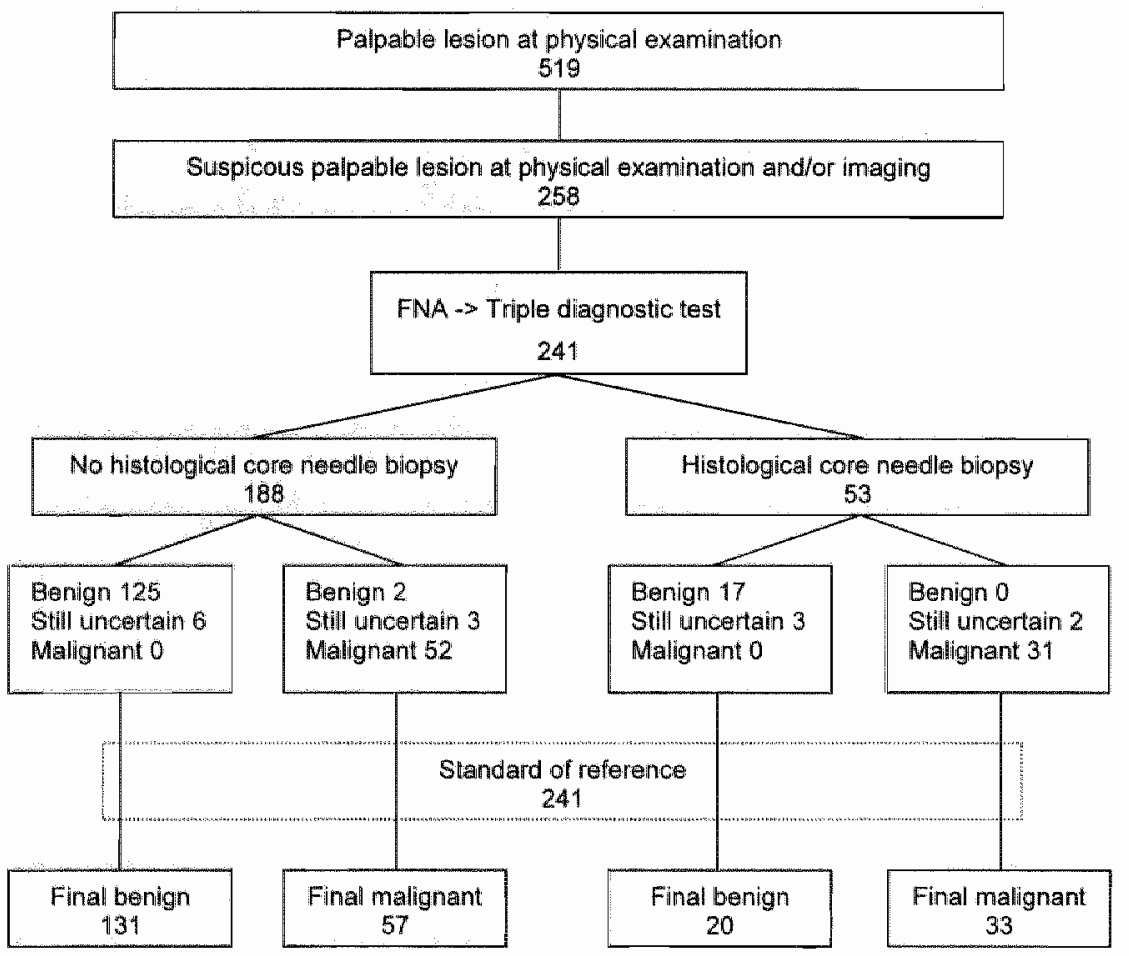

Figure 6.1. How chart of diagnosic tests and the final test result (third row from below) as well as the final dingrosis according to the reference standated (bottom row).

FNAC: Gne needle aspintion cytology. 


\section{STATTSTICAL ANALYSIS}

The diagnostic performance of the various test strategies was described by determining sensitivity, specificity and diagnostic odds ratio (dOR). Non-conclusive tates were defined as the proportion of specimens for which insufficient information or material was obtained to establish a diagnosis in terms of probability of malignancy. Diagnostic odds ratio (dOR) combines sensitivity and specificity into one parameter. The dOR can be calculated by dividing the odds of a positive test result among diseased persons by the odds of a positive test result among non-diseased persons ((sensitivity/ $(1 \text {-sensitivity) })^{*}$ (specificity/(1-specificity)). The sensitivities and specificities were calculated for all possible cut-off points that can be chosen between the different levels of diagnostic outcome for probability of malignancy. The same definitions and cut-off points were used for the analysis of diagnostic modalities (table 6.2 and see also figure 6.1). For the purpose of this analysis, we used the following end-points of the diagnostic test strategies:

a. Physical examination $(\mathrm{n}=241)$;

b. Imaging, which was always conclusive $(n=241)$;

c. Fine needle aspiration cytology was analysed as a separate diagnostic modality $(n=241)$;

d. Triple diagnostic test, the combination of the three above modalities $\left(a .+b_{*}+c_{\text {. }}\right)$ as described in table $6.1(\mathrm{n}=241)$;

e. Histological core needle biopsy $(n=53)$.

Because of the scaled results, ROC analysis was carried out for diagnostic test strategies the five end-points. Ateas under the curve (AUC) were calculated as a measure of diagnostic performance. The non-conclusive results were ranked according to the prevalence of malignancy in that group. The differences between the areas under the ROC-curves were compared using the method developed by Hanley et al" ${ }^{20}$, taking into account that compared curves were derived from the same cases.

In a multivatiate logistic regression analysis, we tried to determine variables which predict a non-conclusive triple diagnostic test and the need for a histological core needle biopsy. Thtee categories of diagnostic variables were defined. The first category consisted of information generally available from medical history, such as age, reason for referral. and history of breast disease. The second category of variables included those variables obtained by physical examination: specific breast symptoms, dianeter of the lesion at palpation and the probability of malignancy at physical examination. The third category consisted of variables obtained from imaging of the breast, like the margins of mammographic lesions and calcifications, the ultrasonographic characteristics of lesions identified, the diameter of the lesion at imaging and the probability of malignancy after imaging. A more detailed description of the variables is shown in table 6.2. First, unvariate analysis selected the variables showing a significant association with the performance of a histological core needle biopsy $(\mathrm{p}<0.10)$. Subsequently, these variables were included in a stepwise multivariate regression analysis with the presence of a histological cote needle biopsy as the dependent variable (entry at $p<0.05$, removal at $p>0.10$ level). 
Table 6.2. Assessment of dingostic modalities for suspecred palpable breast lesions fbold are the best scores at the different cut-off points)

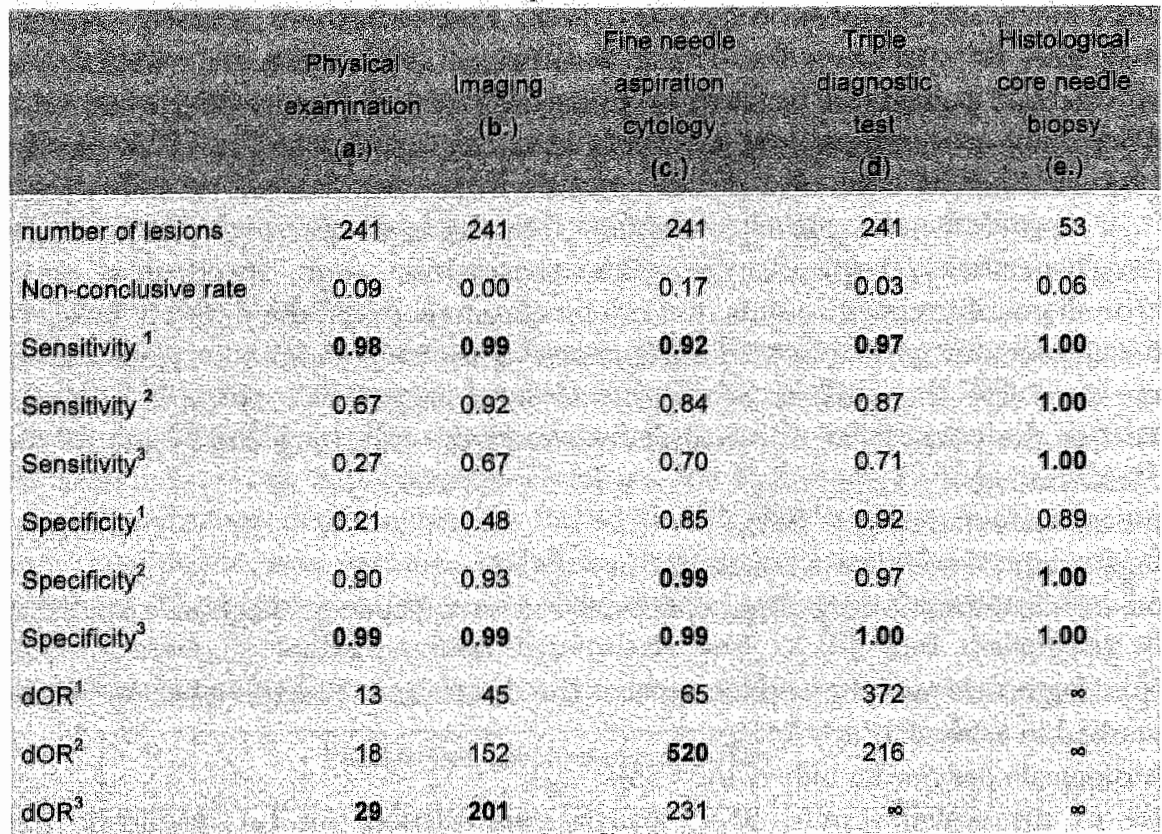

Bold are the highest scores at the different cut-off points

"Cut-off point between centainly benign and probably benign

2 Cut-off point between probably benign and suspicious for malignancy

${ }^{3}$ Cut-off point between suspicious for malignancy and certainly malignant

\section{RESULTS}

Two hundred and fifty-eight suspicious palpable breast lesions resulting from the examination of 3835 breasts formed the basis for this repott. These lesions were eligible for triple diagnostic testing and should have undergone additional fine needle aspiration cytology. If the triple diagnostic test was non-conclusive, a histological core needle biopsy was performed.

After a follow-up of 12 months a total of 96 malignancies were found, leading to a prevalence of $37 \%(96 / 258)$. The histopathological examination of the lesions revealed a carcinoma in situ in 5 cases $(2 \%)$ and an unvasive carcinoma with or without an in situ component in 91 cases $(35 \%)$. The diagnostic tests petformed for these 258 palpable breast lesions are shown in figure 6.1. Although all lesions were palpable, no fine needle aspiration cytology was performed in 17 cases, mainly because of incongruent results of physical examination and imaging which made the physician decide to skip the fine needle aspitation cytology. 


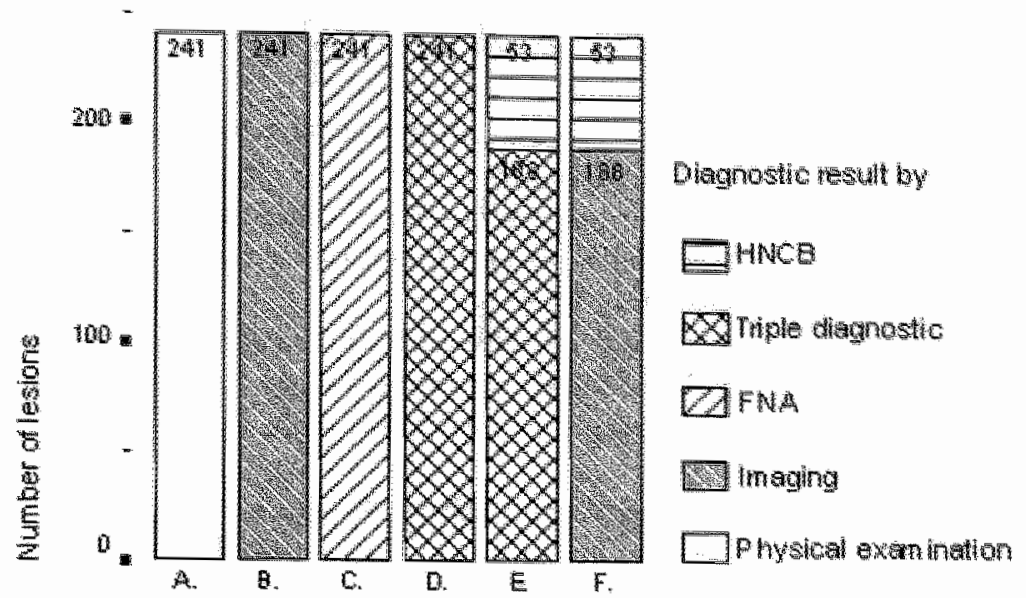

Dianostic erdpoint

Figure 6.2. Different diagnostic modalicies which detcrwined the dingnosis nfter each diagnostic endpoint

HNCB: histological core needle biopsy, Triple diagnostic combination of physical examination, imaging and fine needle aspination cyoblogy, FNAC fane needle aspiration cytology. A.: Diagnostic end-poinr aftet plyysical examination, B:: Diagnostic end-point after imaging, $C$.: Diagrostic end-point after fine needle aspiration cytology, D.: Diagnostic end-point aftet triple diagnoste test, E.: Diagnostic end-point after histological core needle biopsy, if obtained, F. Dingmostic end-point after histological cote needle biopsy without the resalts of the fine needle aspiration cytology/tiple diagnostic test.

\section{DIAGNOSTIC PERFORMANCE AT DIFTERENT CUT-OFT PONTS}

Table 6.2 shows the diagnostic performance at different cut-off points after physical examination(a.), imaging(b.), fine needle aspiration cytology(c.), combined as the triple diagnostic test(d.), and histological core needle biopsy(e.). The best diagnostic performance for physical examination(a.) and imaging(b.) was found at a cut-off point between suspicious for malignancy and certainly malignant ( $\mathrm{dOR}=29$ and 201 ). The best diagnostic performance for fine needle aspitation cytology(c.) seemed to be at a cut-offf point between probably benign and suspicious for malignancy ( $\mathrm{dOR}=520$ ). The best diagnostic performance for the triple diagnostic testing(d.) seemed to be at a cut-off point between suspicious for malignancy and certainly malignant ( $\mathrm{dOR}=\infty$ ). It was not possible to determine the best cut-off point for the histological core needle biopsy from table 6.2 . 
ADDTIONAL VALUE OF THE HISTOLOGICAL CORE NEEDLE BIOPSY

To compare the diagnostic performance of the histological core needle biopsy $(n=53)$ with the other groups ( $\mathrm{n}=241$ ), the following end point groups were distinguished (figure 6.2):

A. The first diagnostic end-point was based only on the result of the physical examination $(n=241)$;

B. A second end-point wats regarded after imaging, which was atways conclusive $(n=241)$;

C. Fine needle aspiration cytology was analysed as a third end-point group ( $n=241$ );

D. A diagnostic end-point was the combined triple diagnostic test. When no fine needle aspiration cytology had been performed or its result was non-conclusive, the result after imaging was used $(\mathrm{n}=241)$;

E. An overall diagnosis was established from the results of the histological core needle biopsy. When no histological core needle biopsy had been performed or it had a nonconclusive result, the diagnosis established at the earlier diagnostic point (D.) was used for analysis $(n=241)$;

F. Actitionally, a theoretical overall diagnosis was established, which included the results of the histological core needle biopsy and the results after imaging. In this group, the fine needle aspiration cytology results were omitted from the analysis $(n=241)$.

Comparing $\mathbf{F}$. with $\mathbf{E}$. allowed the additional value of the fine needle aspiration cytology to be determined.

Figure 6.3 and table 6.4 show the ROC-curves and AUC-ROC of the different diagnostic test end-points. After physical examination all diagnostic tests significantly added accuracy to the diagnosis of a palpable breast lesion $(\mathrm{p}<0.001)$. Fine needle aspiration cytology (C.) (AUC-ROC $=0.922$ ) showed a significant diffetence in AUC-ROC compared to the combined triple diagnostic test(D.) (AUC-ROC $=0.973$ ). Histological core needle biopsy(E.) (AUC-ROC $=0.988$ ) seems to have added diagnostic accuracy to the diagnostic route, although the difference was not significant. When the triple diagnoscic test was omitted from the analysis, histological core needle biopsy still did not add significant diagnostic accuracy to the diagnostic process. Although histological core needle biopsy $(\mathbb{E}$. added significant diagnostic accuracy to the diagnostic procedure after physical examination(A.), imaging(B.) and fine needle aspiration cytology(C.), the diagnostuc accuracy of the combined diagnostic test of physical examination, imaging and fine needle aspiration cytology, known as the triple diagnostic test(D.) did not differ significantly from that of the funal diagnosis(E.) (table 6.4). It thus seems that the triple diagnostic test still has an impotant role to play in the diagnosis of palpable breast lesions.

\section{LOGISTTCREGRESSION ANALYSHS}

The logistic regression analysis yielded 5 significant factors (table 6.4) predicting the necessity of a histological core needle biopsy: densiry of breast tissue at mammography, history of breast disease, family history of breast cancer, aspecific symptoms at physical examination and reason of referm. Unfortunately, these factors have a low predictive factor for whether or not a histological core needle biopsy should be performed (AUC-ROC = $0.667)$. We were unable to establish a prediction model for orniting the fine needle aspiration cytology and perfoming a histological core needle biopsy. 


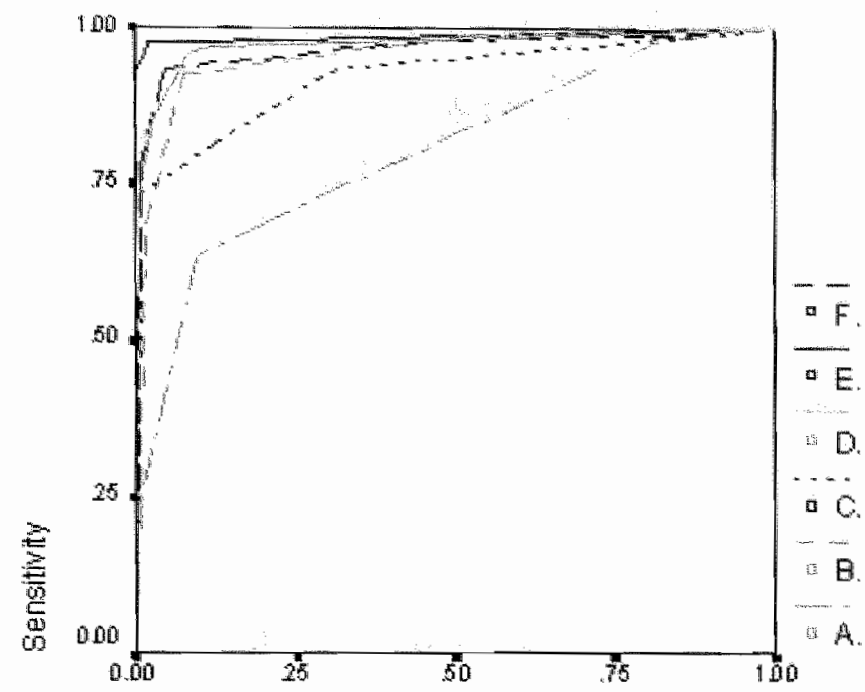

1 - Bnecificity

Figure 6.3. Receiver operating characteristic cutves for the firmal diagnosis at 4 diagnostic test strategy end-points. A. Diagnostic endpoint after physical examination, B. Diagnostic end-point after innaging, C. Diagnostic end-point after fine needle aspication cytology, D. Diagnostic end-point after triple diagnostic test $\mathbf{E}$. Diagnostic end-point after histological core needle biopsy, $F$. Diagnostic end-point after histological cone needle biopsy without the results of the fine needle aspiration cytology/triple diagnostic test

Table 6.3. Areas under de receiver operating characteristic curves at the diagnostic test end-points and their differences.

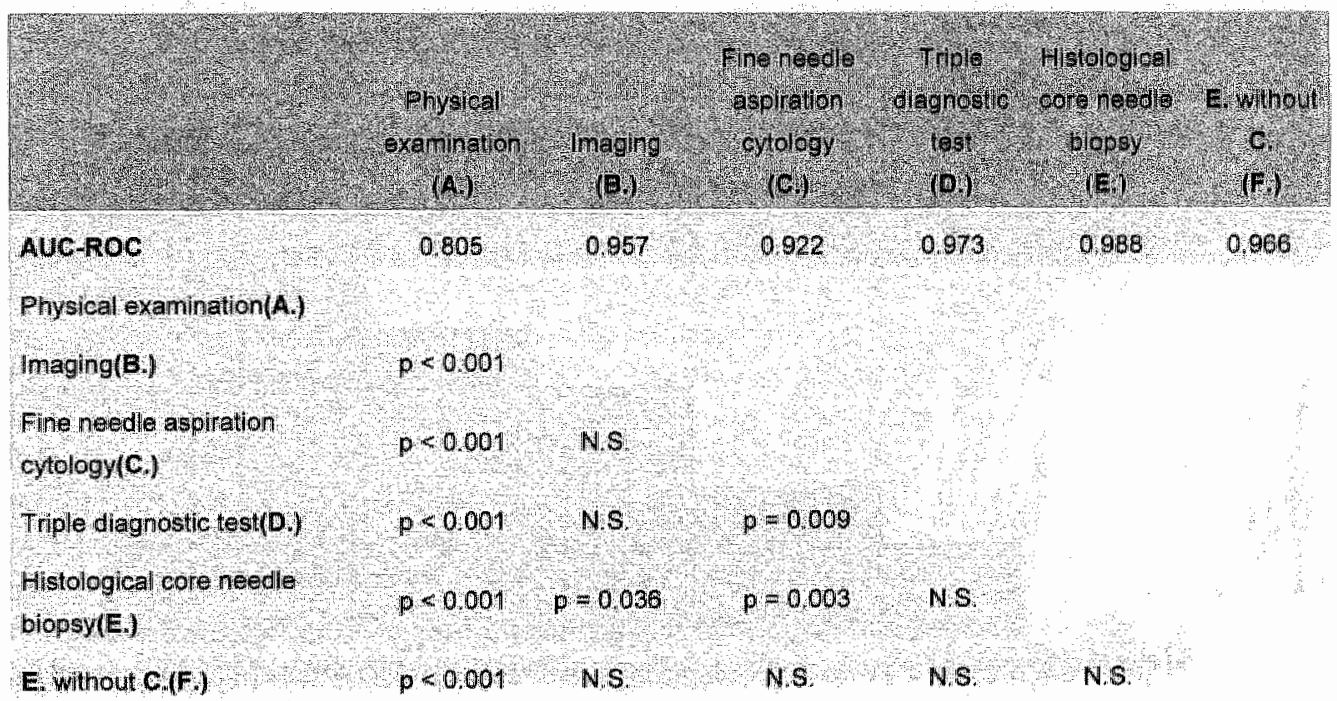


Table 6.4. Diagnostic variables from medical history, physical examination $\left(\mathbb{I}^{\mathrm{P}} \mathrm{E}\right)$, and arvaging, and their significance in uniwarate logistic fegression analysis for the prediction of the need for histological core needle biopsy

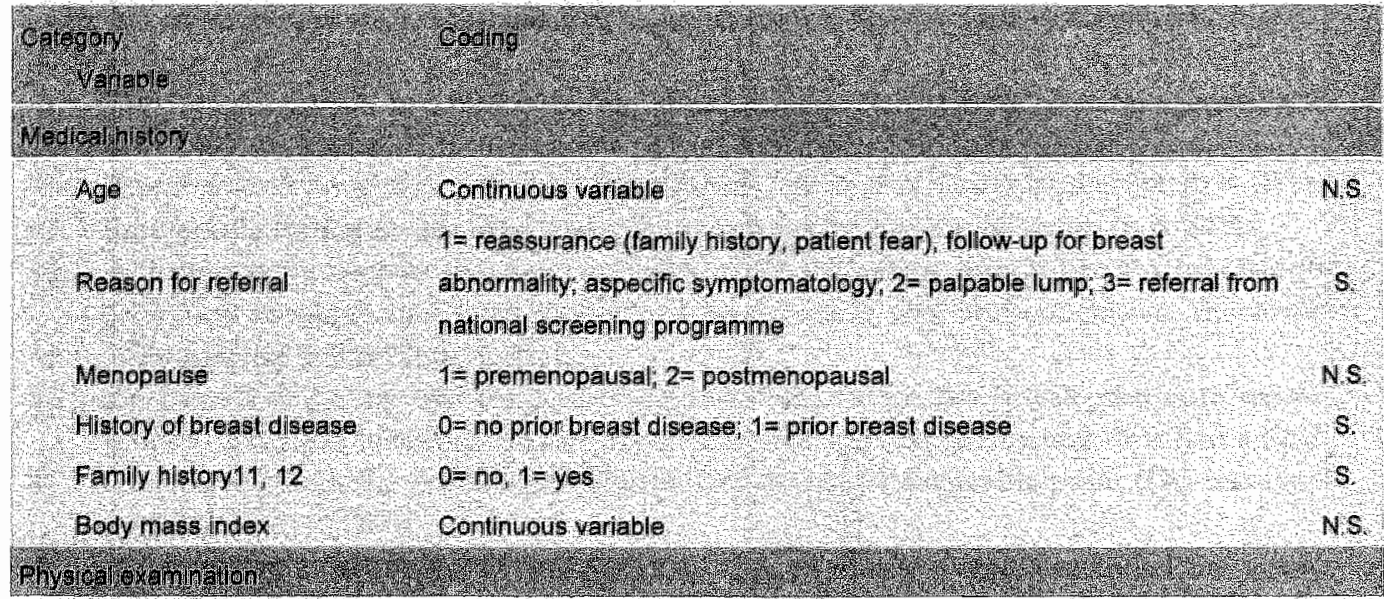

Speeific signs

$0=$ no, $1=$ yes: skin retraction, oedeme peaul dorange, ulceration

Nos

Aspecfic slgne

$0=$ no. 1 - yes asymmetry eczeme, scarring venous marking

6 .

Qumeter at physloa

examinatlon

Continucus varialole

NS

Dognos: 5 at $P E$

$1=$ normal / Indetenminate, - beenign / probably benign, 2 - susplcious nalignant / malignant

Malnmographic leston present of no $1=$ yos

Mamnogrephic margin

$0=$ none, not applicable, 1 - circumscribed, 2 - ll-defined or spiculated

Nicrooralcicalion 0 - no, $1=$ benign calcificatiens, 2 - suspect or malighant calcifications

Qensity treast parenchyina?

Qlamoter at mammography

\section{Dragnosis ar EE+ MMM}

Sonographic isoion present

Soriographic narglm

sonographlo structure

Sonographlo shape

Sonoghaphic

honowoterojeneily

Dlaneter at Senojnohy

\section{Diagnosis at PE MAMHUs}

$1=0-25 \%$ fat containing, $2=26-50 \%$ scattered densities, $3=52-75 \%$ hellerogeneously dense, $4=76$ - $100 \%$, extremely dense

Conilnuaur variablo

0 - noma// indeterminate, 1 = benign/probably benigh 2 - suspicious mallonan/ / nalignant

NS

$0=$ not $=$ yes

NS

0 none, not applicable, $1=$ smooth, $2=$ iregular ? ? ? ? ? ? NS

ot none, not applicable, $1=$ hyoechoic 2 - hyperechoir

$0=$ none, not applicable, t round egg-shaped 2 = Lobulated

Nos

0 mone, not applicable. 1 homogeneous lesion, 2 - heterogeneous lesion

Oonkinuous variable

0e nomal/ indelerminate, / = benign / probably benign, 2 - suspicious malignant $/$ malignant

PE: Physical examination, MAM: Mammography, US: Ultrasonography, S: significant ( $p<0.05$ ), NS: not significant 


\section{Discussion}

This observational study evaluated our dingnostic workup in dealing with stispicious palpable breast lesions. The triple diagnostic test, combining physical examination, imating and fine needle aspiration cytology, adequately diagnosed the majority of lesions. Fror those lesions that cannot be categorised with the combined triple dingnostic test, the histological core needle biopsy is a highly useful tool. Regretrably, it is difficult to predict which lesion will require a histological biopsy to establish a pre-operative diagnosis with certainty without fine needle aspiration cytology.

In the case of breast cancer, a diagnostic test must yield a tissue-specific diagnosis: benign or malignant. To accomplish this, a reliable diagnostic test must be highly sensitivi and specific. The different diagnostic modalities examined in the present study show a trend going from screening-like diagnostics (high sensitivity, although a lower specificity) to a more definitive diagnostic test with a high sensitivity and high specificity tate. As shown in our analysis, the accuracy is still not absolutely perfect at the end of all pre-operative diagnostic tests, and a diagnostic excisional biopsy is still required in selected patienrs $(5 \%)$.

Although physical examination of the breast can sometimes be highly predictive of a malignancy when specific signs are present (e.g. skin retraction), the overall accuracy is not very high. As a measure of diagnostic accuracy, we calculated the dOR, a walue that combines sensitivity and specificity into one estimate. This parameter for the physical examination of the breast was highest at the cut-off point between suspicious for malignancy and certainly malignant. Physical examination is more adequate for a description of the lesion, than for a correct assessment of malignancy.

The diagnostic accuracy was diffetent for the various diagnostic modalities and even varied with the chosen cut-off points. The dOR for imaging and fine needle cytology was highest best at the cut-off point between probably benign and suspicious for malignancy.

To compete with histology, fine needle aspitation cytology has been combined with physical examination and imaging in the triple diagnostic test. Different strategies of combining the available diagnostic modalities have been reported in the literature. Theoretically, it is not appropriate to consider every modality of the triple diagnostic test as being of the same imporrance. Vetto regarded the fine needle aspiration as the most reliable element of the triple diagnostic test ${ }^{13}$, but falled to demonstrate this in his analysis. Some have used a combination of modalities after assessment of every single modality as benign or malignant ${ }^{14}, 15$. This is a more theoretical combination, and many cases will be excluded because of one of more inconsistent results of the three clagnostic modalities. Exclusion of non-conlcusive results from an analysis of diagnostic performance biases the results of tha technique. Morris formulated a score in which the non-conclusive lesions are also evaluated, by assigning a score of 1,2 or 3 points fot a benign, suspicious, or malignant results, respectively. Individual element scores were then added together to yield a total score for each lesion. At our clinic, and in the present study, we used the combination shown in table 6.1. Even before this moment of assessing values of the triple diagnostic test in the diagnostic procedure, various interpretations are possible for the different diagnostic modalities.

Some authors have suggested omitting fine needle aspiration cytology from the diagnosis of palpable breast lesions ${ }^{16,17}$ and going straight on to a histological biopsy. In our 
population, this would have led to 188 additional histological core needle biopsies, with a non-conclusive rate of $4 \%$ (instead of $17 \%$ for the rriple diagnostic test) and an increase in sensitivity from 0.97 to 1.00 , with a constant specificity of 1.00. Another approach would be to perfom a histological core needle biopsy immediately, instead of fine needlle aspiration cytology, in cases where fine needle aspiration is likely to yield non-conclusive results, such as lesions in radiated breasts or in scar tissue, and when there is a discrepancy in size between physical examination and imaging (unpublished data). Unfortunately, we were unable to identify patient- or imaging based parameters that were highly predictive of a non-conclusive fine needle aspiration cytology and triple diagnostic test.

Many authors have suggested that the performance of fine needle aspiration cytology can be improved by using image guidance ${ }^{1720}$. According to Staren, fine needle aspiration cytology was less accurate than histological core needle biopsy, ewen though he performed fine needle aspiration using ultrasound guidedance ${ }^{57}$. Histological core needle biopsy seems to be a modality in its own right, but its result must be obtained with full knowledge of the results of the prior diagnostic modalities, and the final diagnostic assessment should be discussed in a multiclisciplinary meeting ${ }^{21}$.

The data in the present study were collected from a sequence of recommended diagnostic tests performed according to a flow-chart in which a palpable breast lesion at some point was supposed to undergo fine needle aspiration cytology. However, this protocol was occasionally violated, based on assessments by the surgeons, radiologists or pathologists, who were supposed to perform the diagnostic test. This selection is a problem in all observational research on diagnostics. We think our findings reflect daily practice, and the results obtained for this population should be evaluated against those obtained in a more experimental study -lesign.

Another limitation of the present study was the standard of reference. The ideal reference would be histology after surgical excision for all cases, but this would require an intervention in all patients with benign lesions. In the present study, surgical excision was performed in 178 out of 258 cases. For the 80 cases without surgical excision, one yeat follow-up was chosen as the reference. This is a compromise intended to maximise the chance of detecting malignancies that were actually missed and to minimise the chance of finding newly developed cancers. This combination of histology and follow-up is an accepted standard of reference in the literature and has been used to report the results of fine needle aspiration cytology ${ }^{22}$.

There are several advantages to obtaining a pre-operarive diagnosis in patients presenting with palpable breast lesions. If the diagnosis is a malignancy, surgical excision is more often tadical in one operation and the final surgical tesult is less often an ablation of the breast. The frozen-section technique can be ornitted, as this has major disadvantages in terms of logistics and planning. Counselling and optimal use of hospital resources can be facilitated. The surgical treatment can be discussed with the patient before the operation, and a full explanation of the proposed operation and postoperative care can be given.

Before we can decide to omit fine needle aspiration, we need more information about case selection and cost-effectiveness. So far, we are not convinced that fine needle aspiration cytology and the triple diagnostic test should be dropped. Fine needle aspiration cytology has reduced the role of the open excisional biopsy in the diagnosis of palpable breast 
lesions writhout reducing diagnostic accuracy. We should use histological cote needle biopsy in non-conclusive cases to optimise the pre-operative diagnosis of a palpable breast lesion. Unfortunately, we were unable to establish a prediction model indicating whether or not a histological core needle biopsy should be performed without the need for fine needle aspiration cytology. 


\section{REFERENCES}

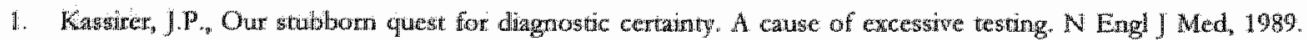
$320(22): 1489.91$.

2. Kaufman, CS, Dellece $\mathrm{R}$, and Jacobson L, Exicising the rexcision: stereotactic core reedle biopsy decreases nect for rexexiston of breast cancer. World J Surg, 1908. 22(10): 1023-7; discussion 1028.

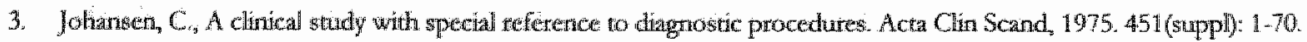

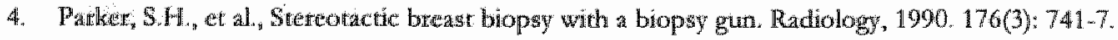

5. Satwen, P., etal., The Mational Health Serwice Bteast Screening Programme and Britsh Association of Surgical Oncology atdit of cqualiny assurance in breast screening 1996-2001. Br J Surg, 2003. 90(1):82-7.

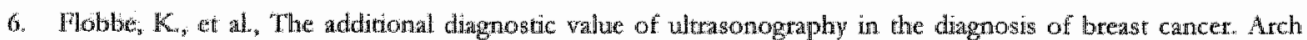
Intern Mcd, 2003, 163(10): 1194.9 .

7. American College of Radiology, Mlustrated Breast Imaging Reporting and Data System (Ilustrated BI-RADS). 1998, Anerican College of Radiolgy. 179.81.

8. Cytology subgroup of the National Coordinating Committe for Breast Cancer Screening Pathology, Guidelines for cytology procedures and reporting on fine needle aspitates of the breast. Cytology Subgroup of the National Coordinsting Commitre for Breast Cancer Scteening Pathology. Cytopathology, 1994. 5(5): 316-34.

9. Hanley, J.A. and MeNell B.J., The meaning and use of the area under a receiver operatug characteristic (ROC) curve. Rudiology, 1982. 143(1): 29-36.

10. Hanley, J.A and McNeil B.J., A method of comparing the areas under receiver operating chasacteristic curres derived from the same cases. Radiology, 1983. 148(3): 839-43.

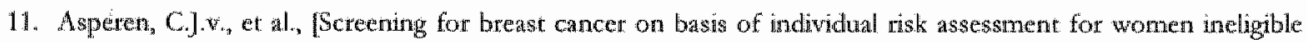
for the national population screening programme] Screening op mammacarcinom buiten het landelijk bevolkingsonderzoek, op grond van individuele tisico-kinschatting. Ned Tijdschr Geneesko, 2001. 145(3): 120-5.

12 McPherson, K, Steel C.M., and Dixon J.M., ABC of breast diseases. Breast cancer-epidemiology, wisk factors, and genetics. Bmj, 2000. 321(7261): 624-8.

13. Vetto, $J_{k}$ er al., Use of the "triple test" for palpable breast lesions yields high diagnostic accuracy and cost savings. Am \Surg, 1995. 169(5): 519.22.

14. Kaufman, Zu, at als, Triple approach in the diagnosis of dominant breast masses: combined physical exanination, mannography, and fine necdle aspintion. J Surgr Oncol, 1994. 56(4):254-7.

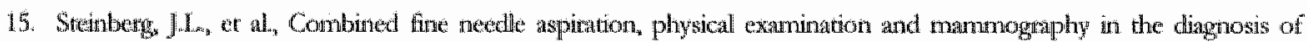
pulpable breast misas: their retation to outconte for women with prinary breast cancer. Can y Sung, 1996. 39(4):302-11.

16. Cartke D., Sudhakaran N., and Gateley C.A. Replace fine needle aspiration cytology with automated core biopsy in the triple insesesment of breast cancet. Ann W Coll Surg Engl, 2001. 83(2):110-2.

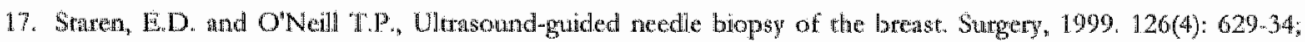
discussion $634-5$.

18. Gordon, P.B. Goldenberg, $S_{2} L_{n,}$ and Chan N.H., Solud beast lesions: diagnosis with US-guided tine needle aspiration biopsy. Radiology, $1993.189(2): 573-80$.

19. Hatada, T., et al. Jsefulness of ultrasound-guided, fine needle aspiration biopsy for palpable breast fumors. Arch Sutg, 1996. 131(10): 1095-8.

20. Monticciolo, DL. and Garrison M.H., Fine needle aspiration biopsy of the breast: importance of benign, nonspecific restals. Acad Radiol, 1998, 5(4):256-60.

21. Bock de, $\mathrm{GH}$, et al, The assessment of genetic tisk of breast cancert a set of GP guidelines. Fam Pact, 1999. 16(1): 71 -7.

22. Zathour, $\mathbb{H}$. and $W \mathrm{ells} \mathrm{C}_{4}$ Andit of statistical data and quality assurance, In: Diagnostic cytopathology of the breast, M.]. Houston, Bilitot 1999, Churchill Livingetone: London. p. 241-52. 


\section{CHAPTER VII}

Histological core needle biopsy of palpable breast lesions: image or palpation-guided? 


\begin{abstract}
The purpose of this study was to determine differences in diagnostic performance of the histological core needle biopsy of a palpable breast lesion obtained by image guidance (stereotactic or ultrasonogtaphic) or by palpation guidance. Methods - A group of consecutive patients with a palpable breast lesion who underwent a histological core needle biopsy was studied retrospectively. Berween January 1999 and July 2002, 239 women with 267 palpable breast lesions underwent a histological core needle biopsy. The biopsy was performed on palpation in 58 cases and by image guidance in 209 cases (ultrasonography in 167 cases and stereotactic in 42 cases). The results of the histology of the core needle biopsy were compared with the findings at excision (216), or 12 months follow-up (51). Results - Patients and lesions were comparable besides lesion size. The mean size of the palpable breast lesions biopted by palpation was significant larger than those biopted by image guidance. However compared to palpation guidance, biopsy by image guidance showed a better sensitivity $(0.69$ vs $0.91, p<0.001)$. Conclusion - Imageguided histological core needle breast biopsies are significantly more accurate than palpation-guided biopsies. Breast tumour size seems to lure physicians to perform a histological core needle biopsy guided by palpation, rather than by imaging.
\end{abstract}




\section{INTRODUCTION}

The combination of physical examination, imaging and fine needle aspiration cytology, known as the triple diagnostic test, of a palpable breast lesion is not always conclusive. This triple diagnostic test has a substantial false-negative and non-conclusive ratel, 2. Surgery of an unknown palpable breast lesion is invasive, requires hospitalisation, is costly, and causes scarring and cleformity of the skin and breast tissue. These features are particularly disadvantageous in cases of a benign diagnosis $(25-30 \%$ of palpable breast masses $\left.{ }^{3}, 4\right)$. A definitive diagnosis priot to surgery is needed to plan the appropriate therapeutic approach and to inform the pattent. A histological core needle biopsy might lead to a more definitive and better pre-operative diagnosis 5,6 .

A histological core needle biopsy of palpable breast lesions can be performed under image or palpation guidance. Image guidance is more expensive and may require additional equipment and expertise. Palpation guidance has the advantage that it can be performed immediately when the medical ground for this diagnostic modality has become clear.

The purpose of this study was to determine differences in diagnostic performance of the histological core needle biopsy guided by imaging (stereotactic or ultrasonographic) or by palpation.

\section{METHODS}

Histological core needle biopsy for palpable and non-palpable suspicious lesions of the breast was introduced at out institution in October 1997. An observational study was conducted during a 43-month period, from January 1999 to July 2002. Seven hundred and eighty-four histological core needle biopsies were performed on suspicious breast lesions of which a pre-operative histological diagnosis was desirable. Two hundred and sixtyseven biopted lesions were palpable and therefore included in this study.

The patient's age, and the site, characteristics (radiological result) and size (pathologist result) of the palpable lesions were recorded. The choice for a biopsy on pallpation was predominantly based on a long waiting petiod $(>5$ days) to get an appointment for image-guided core needle biopsy by the radiologist.

The histological core needle biopsy was performed after anaesthetizing a small area of skin overlying the lesion and the subcutaneous breast tissue in the needle path to the lesion (5-10 cc 1\% lidocaine). A $2-3 \mathrm{~mm}$ incision was made with the point of a fine scalpel blade. A 14 gauge $\times 10 \mathrm{~cm}$ automated biopsy needle (Pro-Mag 2.2, Medical Device Technologies Inc, Gainesville, Florida, USA) in a spring loaded biopsy-gun instrument (Pro-Mag 2.2, Medical Device Technologies Inc, Gainesville, Florida, USA) was introduced and the biopsy-gun was fired between 1 and 10 times to obtain cores of tissue. The amount of cores depended on the macroscopic appearance of the cores and the technical possibilities. A number of 5 cores was thought to be optimal if the ultrasonography or mammogram showed a density. A number of 9 cores was thought to be optimal if the mammogram showed microcalcification ${ }^{7}$. Solid and rigid cores of at least 
$10 \mathrm{~mm}$ length wete assumed to be representative. After withdrawal of the needle, firm pressure to the breast's biopsy location was applied for 3-5 minutes.

Histological core needle biopsies, executed on palpation $(n=58)$, were performed by a surgeon with special interest in senology ( $78^{0} \%$ by 3 experienced sutgeons). Histological cote needle biopsies excuted under image guidance were performed by a tadiologist who had a special interest in breast imaging (77\% by 5 specialized radiologists). Biopsies were performed under stereotactic guidance (Bennet Contour Plus Mammomat-2 unit, Siemens OldelfitBenelux, Delft, The Netherlands) with the patient in sitting or lateral lying position in 42 cases. Biopsies were performed under ultrasonographic guidance in supine position using an ultrasound scanner (HDI5000, ATL, Bothell-Washington, USA) with a $12-5 \mathrm{MHz}$ linear array transducer handheld probe in 167 lesions. The choice between a stereotactic or ultrasonographic guided histological core needle biopsy reflected the radiologist's assessment of the suitability and visibility of the breast lesion and his own experience.

The specimen was fixed in $10 \%$ buffered formalin (Unifix, Klinipath, Duiven, The Nethetlands) and paraffin sections were stained with Ehrlich's acid haematoxylin and eosin. The pathologist made his report with full knowledge of clinical, radiological and earlier cytological information. The histological diagnoses wete divided into three categories: (1) nomal or benign breast disease, (2) not clearly benign not malignant for technical and histological reasons (including not tepresentative, atypical ductal hyperplasia and lobular carcinoma in situ (LCIS)), or (3) malignant (including ductal carcinoma in situ (DCIS) and invasive catcinoma (with or without in situ carcinoma)).

The reference standard for the presence or absence of breast cancer was determined by pathology results from surgical excision $(n=216)$ and during 12 month follow-up $(\mathrm{n}=51)$. Pathology results were retrieved from the hospital pathology department. We abstracted data from cases noted at diagnosis and 12 months later. In case of no indication for malignancy or minimal doubt about the diagnosis, no further histological results were required. Results were defined as true negative when no pathology was reported in either system.

\section{STATISTCAL ANALYSIS}

To analyse the diagnostic tests in this setting, non-conclusive rate, sensitivity and specificity were determined. The non-conclusiwe results were recoded as false positive when the final result was benign and false negative when the final result was malignant or stayed non-conclusive. We choose this recoding because we think it best follows the clinical practice in which a non-conclusive result will be followed by further diagnostic modalities because nalignancy cannot be excluded.

A $p$-value $\leq 0.05$ was considered as statistically significant.

\section{RESULTS}

Between January 1999 and July 2002 a histological core needle biopsy was performed of 267 palpable breast lesions in 239 woman (mean age of 53.0 years). The final diagnosis was a malignancy in 162 cases within these 267 lesions $(61 \%)$. 
Some characteristics of patients and lesions in the palpation-guided and image-guided histological cote needle biopsies are shown in table 7.1. Whet the histological core needle biopsy was performed on palpation guidance, the median number of cores was 5 (tange 2-10). On ultrasound guidance a median number of 5 cores was taken (range 1-9). On stereotaxy too a median of 5 cores were taken (range 4-9, usually 9 in case of mictocalcifications). The Mann-Whimey $U$ test shows the lesion size to be significantly different in the palpation gtoup, compared to the imaging group $(\mathrm{p}<0.001)$. The table also shows the diagnostic performance of the three biopsy techniques. Ductal carcinoma in situ (DCIS) only was found in 7 histological core needle biopsies (nwice by stereotaxy and 4 times by ultrasonind guidance). Once, the excised specimen on histological core needle biopsy (stereotactic guidance) showed the diagnosed DCIS to be scar tissue in a patient as a result of breast conserving therapy from earlier breast cancer. In two cases DCIS was confirmed on excision (ultrasonographic guidance). Three times DCIS was combined with invasive carcinoma in the excised specimen (once after steteotactic guidance, twice after ultrasonographic guidance).

Table 7.1. Characteristics of parients and lesions, and dagnostic performance of the histological core needle biopsy techniques

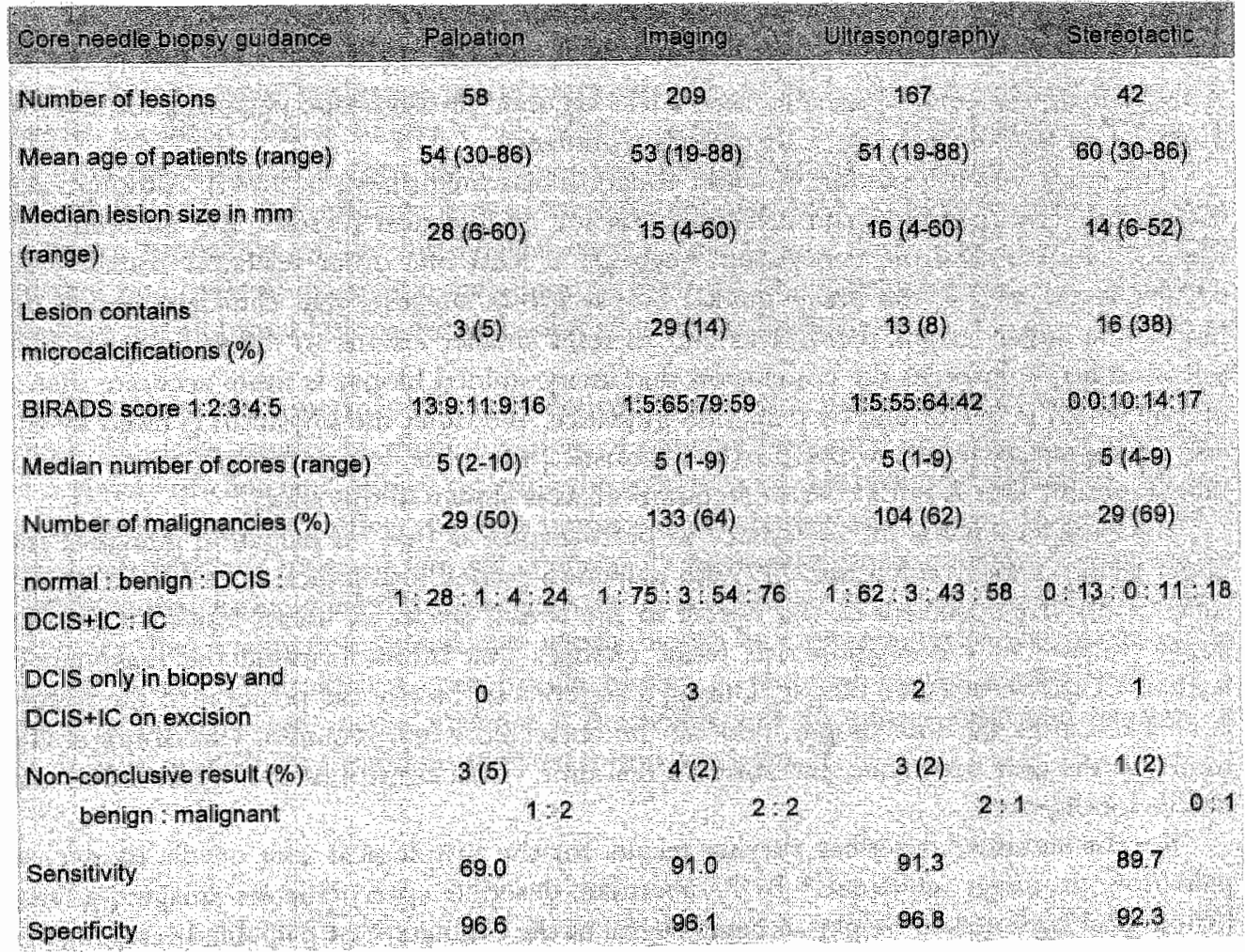

BIRADS score: Breast Imaging Reporting and Data System score ; $1=$ no abnotmalities, $2=$ benign, 3

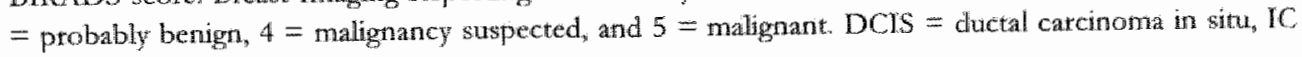

$=$ invasive carcinoma 
Table 7.2 shows the p-values of the comparisons of the sensitivity and specificity between the different biopsy techniques. Palpation shows a significant difference in sensitivity compared to imaging; stereotactic as well as ultrasonographic. Specificity is not significantly different between the biopsy modalitics.

Table 7.2. Puallues of the diagnostic performance measurements between the different biopsy techniques.

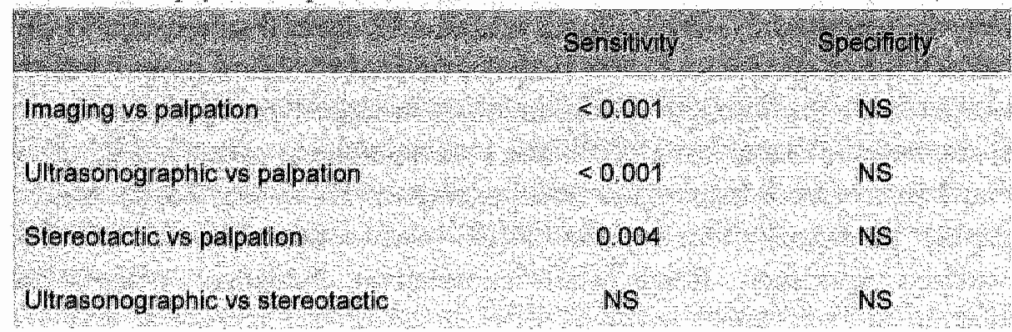

N.5, not wignificant

\section{Discussion}

A biopsy without image guidance seems less accurate in diagnostic performance, even if much larger lesions are biopted by palpation guidance.

The study was not randomised and selection bias might have occurted. Although our impression was that the main selection was for of logisticall reasons, the difference in tumour size between the two groups suggests at least one other selection criteria. The smaller lesion size in the image-guided biopsy group suggests that clinicians choose to biopsy the larger lesions themselves and to refer smaller lesions to the radiologist. This. selection bias reinforces the conclusion that image-guided biopsy is more accurate than a biopsy which is performed by palpation-guidance. We think the physician is lured by the size of the breast lesion to perform a diagnostic procedure, which he believes to yield a reliable result. This is not a correct assumption, as is shown in this study.

An explanation for the difference in performance is that on palpation guidance the target lesion is more often missed. With palpation-guided histological core needle biopsy there is no visual control of the needle in the breast lesion. A breast lesion might feel larget because of the desmoplastic tissue changes that often surround the malignancy, leading to a false negative biopsy. During a stercotactic biopsy the position of the needle is checked after the first biopsy, and can be corrected when required. Ultrasonographic biopsy is the only technique that shows a real-time visual control of the breast lesion and needle localisation.

Recent literature describes varying results for the histological core needle biopsy on palparion or image guidance. 4,90 J.uberman describes percutaneous imaging-guided histological core needle biopsy as being useful in the evaluation of palpable breast masses that are small, deep, mobile, vaguely palpable, or multiplet. In $2002 \mathrm{Agarwal}$ found a high sensitivity of free-hand percutaneous core biopsy for the diagnosis of malignancy in 
palpable breast lesions in which he concluded that image-guidance is unnecessary 10 . One year later Shah found a more common false-negative diagnosis of beast carcinoma in a histological core needle biopsy perfomed without image guidance, and a lesser degree of accuracy in image-guided biopsies?

The ductal carcinoma in situ lesions diagnosed at a histological core needle biopsy are a reason to be careful in determining whether invasive histology is present once the complete lesion is excised and analyzed. We found 3 out of 6 lesions to be invasive in the final histology after excision in which the histological large needle cotes showed only ductal carcinoma in situ. For decision making in performing a sentinel node procedure, it is important to realize this dilemma as a sentinel node procedure in an operated breast is less reliable in its diagnostic performance.

Palpable lesions are also suitable for fue needle aspiration cytology performed by palpation guidance. This technique is unfortunately only conclusive in the combination of the triple diagnostics. By itself the pathologist requires special training and experience in otder to perform and interpret it. The combination of physical examination, imaging and fine needle aspiration cytology has a false-negative rate of $0-35 \%$ and a non-conclusive rate up to $48 \% 1,2,11$. Performing the fine needle aspiration cytology, image guidance will most likely increase the diagnostic performance of the triple diagnostic test.

The cost-benefit tatio between histological core needle biopsy and surgical breast biopsy is still not clear. There is some evidence of a cost-benefit in the literature when breast lesions were evaluated pre-operatively with histological core needle biopsy ws needle localized breast biopsy. $5,6,12$ Thete seems to be an economic advantage if stereotactic histological core needle biopsies ate performed in a centralised scenario 5 . Research into the cost-effectiveness of the different diagnostic techniques and of different guidance modalities of the histological core needle biopsy is necessary. Unfortunately, finding one optimal diagnostic technique to perform in every breast lesion is not likely, because not all breast lesions are accessible to every technique.

The more a study is performed under controled experimental conditions the less it says about the daily practice in which a variety of patients presented in a variety of situations to a vatiety of clinicians. Whilst realizing the weakness of this observational study, we also consider the tesults to reflect the daily practice as it is performed in many hospitals with at range of clinicians more or less experienced in diagnosing breast lesions. Therefore we conclude that image-guided histological core needle biopsy by a radiologist has a higher accuracy than a palpation-guided core needle biopsy by a sutgeon guided by his palpating hands. When a histological core needle biopsy is required in the management of a palpable breast lesion, image guidance is preferable and the organisation and logistics of diagnostic procedures should be adjusted to this accordingly. 


\section{REFERENCES}

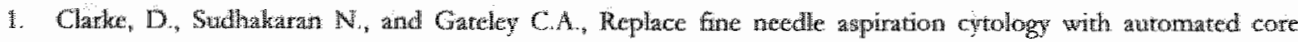
biopsy in the triple assessmen of breast cancer. Am R Coll Surg Engl, 2001. 83(2): 110-2.

2. Vetto, J. wet al., Use of the "triple test" for pabable breast lesions yields high diagnosuc accuracy and cost gavinge: Am J Sutg: $1995: 169(5): 51922$

3. Zonderland, H.M. et al, Pre-operative needle biopsy: an improvemert in palpable breast tumors with strong thdicatione for matignancy. Ned Tjuschir Geneeskd, 1996. 140(39): 1952-6.

4. Uiberman, L, et al, Palpable breast masses, is there a tole for percutaneous unaging guided core biopsy? AJR An ] toentgend, $2000,175(3): 779-87$.

5. Buyss-van der Woude, $T$, et at, Cost comparison between stereotactic large-cote needle biopsy versus surgical excision biopsy in the Netherlands. Eur J Cancer, 2001. 37(14): 1736-45.

6. Jialty, $13, \mathrm{~N}$, et al. Cosi-benefir analysis of biopsy methods for suspicious mammographic lesions; discussion 994-5. Arch Surg, 2001. 136(9):990-4.

7. Breniner, R. I, et al, Percuntecus Core Biopsy of the Breast: Effect of Operator Experience and Number of Samples on Diagrostic Accuracy. Am J Roentgenol, 1996. 166:341-6.

8. American College of Radiology, Ihwstated Breast Imaging Reporting and Data System (nlustrated BI-RADS) 1998, American College of Radiology. 179 81

9. Shah, VI, er al, Follse-Negative Core Needle Biopsies of the Breast: An Anallysis of Clinical, Radiologic, and Pathologic Findings in 27 Consecutive Cases of Missed Breast Cancer. Cancer, 2003. 97(April 15): 1824-31.

10. Agarwal, Ti", er al, Core biopsy versus FNAC for palpable breast cancers. Is image guidance necessary? Eur J Cancer, $2002,39(1): 52-6$.

11. Motris, AM. et al, Comparing the costeffectiveness of the triple test soore to traditional methods for waluaring palpable breast masses. Med Care, 2003. 41(8): $962-71$.

12. Liberman, L, Percutancous. Irnaging-Guided Come Breast Biopsyt State of the Art at the Millenmiam. Am J Roentgenol, 2000. 174(May): $1191-9$ 


\section{CHAPTER VIII}

General discussion and conclusions 


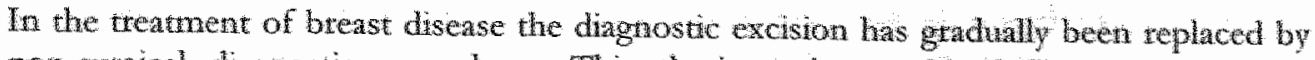
non-surgical diagrostic procedutes. This thesis evaluates the daily phactice of the pre-operative diagnostic route for breast symptoms that migh suggest malignancy. A pre-operative certatn diagnosis facilitates counselling and the optmal use of hospitat resoutces. The surgical treatment can be discussed pu-operatively wh the patient and full explanation of the proposed operation and postoperative cate can be given. Additionally an accurate pre-operative diagnostic examination induding sampling of cels or tissue by methods that are less invasive than surgical excision of the breast lesion are associated with a significanty higher lkelihood of tumour-free excision margins (three thes higher) and less mutlating operations, as the mastectomy is. However, it is not cleat in all situations which diagnostic procedures are nost efficient.

\section{DLAGNOFT MODALTTES UNDER SUDY}

In dally toutine non-invasive diagnostic procedures of the brenst are history taking, physical examination, manmography and viltrasonogtaplyy. History taking determines the risk for breast cancer in the physician's mind and infuences futther medical decisionmaking.

Whether a breast lesion is palpable or not on physical examination depends on the size and consistency of the lesion, on the size and consistency of the breast, and on the expenence of the physician. For example, a small, vaguely defined lesion might be papable in a mastopatic breast if the plysician has a high level of experience, whereas a latge well-defined lesion in a small fatty breast night be missed by a physician with a limited lewel of experience. As a consequence the palpability of breast lesions is a subjective matter, which has to be expressed on a gradual scale. However, in studies a differentiation is often made between palpable (chapter III, VI, VII) and non-palpable lesions (chapter I). This partly depends on the different chatacrevistics and technigues, which ate avaitable for palpable and non-palpable breast lesions respectively.

Nevertheless there is a correlation between patpability and the size of a breast lesion and moreover, thete is a correlation between breast cancer tumour size and the prognosis of breast cancer. In some cases breast tumout size can be used for pre-operative decisionmaking, for instance to determine whether neo-adjuvant systemic therapy is indicated or not, or to decide whether a sentinel node procedure is watranted. The problem, which is addressed in this thesis, is which technique is most accurate in comparison with histology to measute tumour size: physical examination, mammography of ultrasonogtaphy. When comparing these techniques in a large cohort of patients ulmasonography seerns to be the best estimator of the histological size of a malignant breast tumour. However, because of the wide $95 \%$ confidence interval, it remains difficult to predict the exact breast tumour size of an individual breast tumour in comparison with histology. Therefore we recommend caution in the pre-operative estimation of the clinical T-classification. Whenever pre-operative clinical $T$-staging is used in decision-making of breast cancer treatment, the results of this study indicate that ultrasonography is the preferred technique to determine the size of the breast numour.

Ultrasonography is a non-invasive diagnostic imaging modality for examining breasts, which improves the overall diagnostic yield when added to physical examination and mammography (chapter IV). This study indicates that the diagnostic value of 
ultrasonography shows the greatest increase in patients with palpable breast lumps and in patients referred with an abnormal mammogram (for example in the national breast screening programme). Therefore all patients in these categories have to be schedulled for breast ultrasonography. In doing so, the planning of breast imaging can be optimised and the number of redundant ultrasonographic examinations reduced. Additional research will be needed to determine the cost-effectiveness of the application of breast ultrasonography in these specified groups of patients.

In all diagnostic procedures interobserver variation has to be taken into consideration. Findings at history taking and physical examination ( $\mathrm{eg}$, family history of breast cancer or the palpation of a palpable breast lump) cannot always be confirmed by another physician at a second occasion. This interobserver variation, often described in a Kappa score on a scale from 0 (maximal variation) to 1.00 (no variation), is a problem in diagnostic imaging as well. The literature shows substantial interobserver variation in observing radiographs; for instance the Kappa value in the assessment of chest radiogtaphs to diagnose pneumonia varies between 0.37 and $0.69^{1}$ and to observe lung nodules between 0.52 and $0.73^{2}$. Obtaining chest tadiographs is a very standardized technique. This, however, is not the case in ultrasonography. Moreover, in ultrasonography of the breast, there is an additional soutce of variation in making a diagnosis, besides that of the observer who observes the images: the operator who obtains the image to make a diagnosis. This combination of interoperator and interobserver variability, which in this thesis is called the "interexamination" variability of ultrasonography of the whole breast, is moderate and quite acceptable with Kappa values varying between 0.63 and 0.83 (chapter V).

To obtain a definitive pre-operative diagnosis besides physical examination and imaging, cell or tissue examination is necessary. Fine needle aspiration cytology can be diagnostic if its interpretation is in concordance with the interpretation of the physical examination and of the images (e.g. triple diagnostic test). Fine needle aspiration cytology might seem a simple procedure, but obtaining the cells and interpreting the cytology requires special training and expetience. The technique had a non-conclusive tate $(0.17)$ in our population. This non-conclusive tate is the weakest point of the fine needle aspiration cytology. Overall, fine needle aspiration cytology is the strongest pillar of the triple diagnostic test (AUC-ROC 0.922). Physical examination was shown to be the weakest pillat in the triple diagnostic test (AUC-ROC 0.805). We tried to identify patient- or imaging-based parameters that were highly predictive of a non-conclusive fine needle aspiration cytology and triple diagnostic test, but we were not able to find any. Contrary to our expectations, the analyses of chapter VI did not provide support for omitting fine needle aspiration cytology in all or in selected patients.

Given the minor value of the physical examination in the triple diagnostic test for palpable breast lesions, one might consider that leaving physical examination and assessing the palpability and probability of malignancy of a breast lesion out of the triple diagnostic test might not worsen its diagnostic performance, which makes the combined diagnostic test of imaging and fine needle aspiration cytology also available for nonpalpable lesions. 
Cell and tissue sampling of non palpable breast lesions makes image guidance necessary. Chapter VII shows that even for palpable breast lesions a better perfomance of the histological core needle biopsy of a palpable breast lesion is obtained when guided by imaging techniques, compared to the histological core needle biopsy of a palpable breast lesion guided by palpation. Therefore all breast-cell ot breast-tissue sampling methods should be performed by image guidance.

\section{GUTDELINES IN BREAST CANCER DLAGNOSTICS}

For the Netherlands national guidelines in breast cancer screening and diagnostics have been described since $1980 \mathrm{~s}^{3 \mathrm{in}}$ Guidelines in breast cancer diagnostics do not constinte a standard nor a protocol, which have to be followed without deviation. The ultimate result of these guidelines should be decreasing morbidity and mortality from breast disease and its treatment. Although the clinicians in our hospital claim to follow these guidelines rather rigorously, analysis of the cohort of patients studied in this thesis shows that it was not rare for clinicians to diverge from these guidelines. "This happened because of what can be called a "loop-construction" in the diagnostic process, which cannot be caught in a guideline easily. A "loop construction" means that decisions made in an earlier stage of the diagnostic route can be adjusted by results from a later step in the diagnostic pathway due to interactions and discussion between surgeon, mdiologist, pathologist and oncologist at any point during the diagnostic process or in a multidisciplinary consensus meeting. For example, a certain malignant fine needle aspiration cytology turns the decision of a probably benign lesion at physical examination or at imaging into a decision of a more probably malignant lesion when the results of these diagnostic modalities are reconsidered. These interactions are most often helpful, and are difficult to incorporate in detailed guidelines.

In general our conclusions support the Dutch national guidelines. We would like to suggest in the next version of the guidelines mote emphasis on the utrasonographic breast examinacion in all patients with a palpable breast lesion and a known lesion on mammography. The ultrasonography report must contain information about the breast lesion in detail including its size. Moreover, the suggestion to use image guidance to perform all breast lesion tissue sampling should be emphasized. Finally, the combination of imaging and fine needle aspiration cytology should be further explored for definitive diagnosis of a breast lesion if the physical examination results are not usable or not in concordance.

\section{FURTHER RESEARCH}

Randomised controlled research gives the highest grade of evidence-based medicine. A perfect controlled experimental study might not reflect the daily practice in which a variety of patients present a vatiety of (a)symptomatic situations to a variety of clinicians, who have to deal with logistics and the availability or unavailability of diagnostic modalities. While realizing the weakness of the retrospective, observational studies (as reported in chapters $\mathbf{I}$, VI and VII), we tried to observe and to describe conscientiously this daily practice. However, consensus about how to guide a patient with breast complaints ot symptoms is a dynamic entity. Constant observation, registration, evaluation and audit of diagnostic (and therapeutic) methods is necessary to keep in touch 
with the reality of a physician's daily performance and to benchmark with others to realize improvements.

In addition to the diagnostic modalities evaluated in this thesis, other diagnostic innowations are present in the literanure and are already used: Digital mammography, Magnetic resonance imaging (MR mammography) ${ }^{8-14}$, Scintimammography (9mTc-MTBI, ${ }^{201} \mathrm{TT}^{12}{ }^{12}, 13$, Computed tomography (CT), Positron emission tomography $((\mathrm{FDG}-) \mathrm{PET})^{14}$, 15. In high-fisk groups or problematic cases, the cost-effectiveness of technical innovations may be justified ${ }^{16-18}$, although these modalities are still a matter of debate, and need further prospective evaluations with approptiate clinical trials designed to evaluate the impact of these approaches in improving survival and quality of life ${ }^{19}, 20$.

Although cost-effectiveness studies are of little interest to an individual patient, they are essential to achieve economically justified decision-making protocols to diagnose and treat breast cancer. These studies include the cost-benefit analysis as well as diagnostic performance and patients' well being and quality of life dimensions. Much is written abour the cost-effectiveness of newly introduced techniques. It should be of interest to obtain cost-effectiveness conclusions about doing less: for example, about omitting fine needle aspiration cytology and histological core needle biopsy when the combination of physical examination and imaging is clear about a certain maligaant breast lesion. Above all, we should not lose sight of the ultimate goal of decreasing morbidity and mortality from breast disease and its treatment in a patient.

\section{CONCLUSTONS OF THIS THESTS}

- Surgical treatment of non-palpable breast cancer leads to more conservation of the breast when the lesion is known to be malignant before surgery (chapter II).

- Ultrasonography compared to physical examination and mammography estimates the pathological size of a malignant breast tumour best (chapter III).

- Systemic application of whole breast ultrasonography as an adjunct to mammography and clinical cxamination significantly improves the overall diagnostic yield. The diagnostic value increases most in patients with palpable breast lumps and in parients referted with abnormal screening mammography results (chapter IV).

- Whole breast ultrasonogtaphy shows a substantial interexamination agteement and adds consistency to mammography and physical examination (chapter $\mathbf{V}$ ).

- The triple diagnostic test (combination of physical examination, imaging and fine needlle aspiration cytology) still has an important contribution in the diagnosis of palpable breast lesions. The histological core needle biopsy optimises the preoperative diagnosis of a palpable breast lesion when the combined diagnostic test is non-conclusive (chapter VI).

- Innage-guided histological core needle biopsy yields significantly more frequently a conclusive histological diagnosis than palpation-guided biopsies. Size seems to lure the physician to perform a histological core needle biopsy guided by palpation (chapter VII). 


\section{REFERENCES}

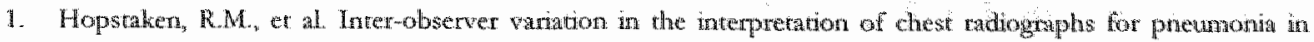
community acquired lower respinatory tract infections. Clinical Ratiology, 2004, 59.743-52.

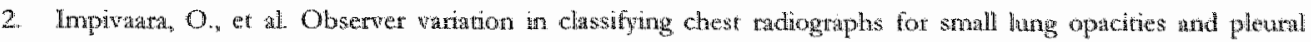
sbromalities in a popularion samples. An I Ind Med, 1998; 34:261-5.

3. CBO, Beeldwommende diagnostick pan de mamma. 1993, CBO: Utrech.

4. $\mathrm{CBO}, \mathrm{Mammascreaning} \mathrm{en} \mathrm{nadere} \mathrm{diagnostiek} \mathrm{1988,} \mathrm{CBO} \mathrm{Utrechr.}$

5. NABON. "Organsation, diagnostics and treatment of breat disense in The Netherlands". 1995. NABON.

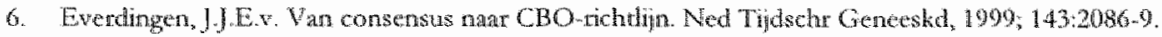

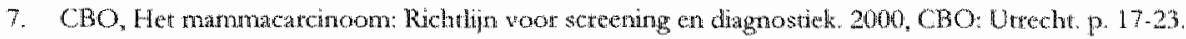

9. Berg, W.A, et all Diagnostic Accumey of Mammogtaphy, Clinical Exmmation, US, and MK Imaging in Pre operative Assesment of Breast Cancer. Radiology, 2004, 233.83049

9. Goethem van, ML., er al. MR mamnography in the pre-operative suging of brenst cancer in paticns whet. dense breast tissne: comparison with mammography and whtasound. Eur Radiol, 2004; 14:309-16.

10. Mallur $\mathrm{S}_{\text {. }}$, all. Comparison of writen reports of mammography, sonography and mengetic resonamce mammography for pre-operative evaluarion of breast lesions, with special emphasis on magnete asonance mammograply. Breast Cancer Res, 2001; 3:55-60.

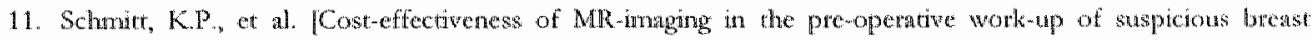
lesions]. Rofo Fortuschr Geb Rontgenstr Nuen Bildgeb Verfabr. 2001; 173:808-901.

12. Buscombe, JR, et al. Prediction of the Usefulness of Combined Manmograpty and Scintinammography in Suspected Primary Brease Cancer Using ROC Curves J Nucl Med, 2001; 42:3.8.

13. Hillner, B.E. Decision analysis: MTBT imaging of nonpalpable breast abnormalicies. I Nat Med, 1997; 381772 8.

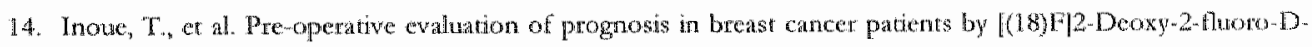
glucose-positron envission tomography. J Cancer Res. Clin Oncel, 2004; 130:273-8.

15. Bombardiet, E. and Crippa $F$. PE $T$ imaging in brease cancer. Q J Nucl Med, 2001; 45245-56.

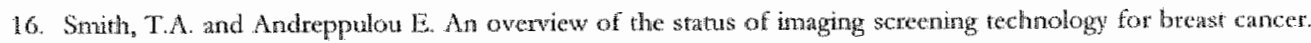
Ann Oncol $2004:$ 15 Suppl 1:118-26.

17. Watter, C, el al. Clinacal and diagnostic value of premoperaive MR mamography and FDG PET in suspicious breast lestons. Eur Radiol, 2003; 13:1651-6.

18. Hlaryatsch, A. wet al Pre-operative Assessment of Breast Cancer: Sonography Verwus MR Inaging. AJR Am J Roentenol, 2002; 179:1493-501.

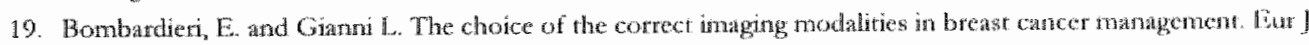
Nucl Med Mol loxaging, 2004; 31 Suppl 1 s 1701 -86.

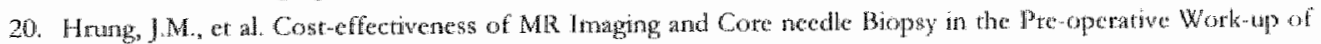
Suspicious Breast Lesions. Radiology, 1999; 213.39 .49 . 


\section{Chapter IX}

\section{Summary}

"Verdriet bevordert hee denken en pin is de dnjfuect wan ons leven" (Picasso wolgens sabartés, blawe periode 1901 -1904) 
Breast cancer has the highest incidence of cancer among women in the Netherlands. Over 10,000 new breast cancers are diagnosed every year. One out of every nine women will get breast cancer at some point in her life. In addition to the life-threatening consequences of breast cancer itself, the fear of mutilating surgical procedures and a period of uncertainty cause much distress.

For general practitioners and specialists it is essential to tecognize an increased risk of breast cancer, a palpable breast lump, or other breast cancer symptoms, and to indicate the right diagnostic route. Routine breast diagnostics are physical examination and imaging. The radiologist responsible for the inaging can use different techniques to describe the breast. The most commonly used imaging techniques are mammography and ultrasonography.

For a definitive diagnosis, cytology and/or histology of a breast lesion are necessary, in addition to physical examination and imaging. The surgeon, radiologist or pathologist obtains with a 21 Gauge needle or a large 14 Gauge needle a representative sample of the suspicious breast lesion. The pathologist investigates the samples after colouring under a microscope. All diagnostic modalities have their false-positive and falsc-negative results. For this reason it might not be clear at the time of surgical excision of a breast lesion if it is a benign or maliguant lesion. It is the surgeon's job then to excise the breast lesion and present it to the pathologist for definitive diagnosis. Chapter II of this thesis shows that a correct pre-operative diagnosis of a breast lesion leads to a better curative treatment. In a population of 400 non-palpable breast lesions (208 malignant lesions), the seventy-seven lesions that were pre-operatively found to be malignant were three wimes more often excised with tumour-free matgins and were less often treated with an ablation of the breast.

Diagnosing a breast lesion correctly pre-operatively also means estimating a realistic tumour size. Breast tumour size determines the prognosis of the disease and might indicate for a more or less aggressive therapy. Chapter III describes the possibility of being able to estimate breast tumour size precisely and pre-operativelly using physical. examination, mammography or ultrasonography. A sample group of 105 malignant breast tumours was used. These results were compated to the histological size, which was determined by the pathologist after surgical excision of the tumour. The results of ultrasonography showed a significandy more accurate estimate of breast tumour size compared to the results of physical examination and mammography. In general the size of a breast tumour is equal to the ultrasonographic stze $+3 \mathrm{~mm}$.

Chapter IV presents the results of a study performed in the Univetsity Hospital Mastricht between October 1999 and August 2000. The main goal of this study was to determine the additional value of ulrasonography of the whole breast alongside physical examination and mammography in the diagnosis of breast cancer. Of 2020 consecutive outpatient patients who were referred for breast inaging, 3835 breasts were investigated by physical examination, mammography and ultrasonography. All diagnostic modalities were scored on a 5 point scale for probability of malignancy: $1=$ no abnormalities; $2=$ benign; $3=$ probably benign; $4=$ suspicious for malignancy, and $5=$ malignant. "The histology results of histological core needle biopsies and surgical excisions in the 12 months following inclusion in the study were used as refarence standards for breast 
cancer. Breast cancer status was considered negative when no pathology was reported. A trotal of 129 breast cancers were diagnosed in 127 patients $(127 / 2020=6.3 \%$ prevalence).

Ultrasonography detected 8 extra breast cancers and correctly downgraded 332 suspicious lesions at physical examination and mammography to a negative diagnosis. Statistical analysis showed that the diagnostic performance of the systemic application of ulltrasonography, adjusted to physicall examination and mammography, improved the overall diagnostic yield. This improvement was the strongest in patients referred for palpable breast lumps or referted from the national breast cancer-screening programme.

Chapters III and IV show the positive influence of ultrasonography of the breasts in detecting breast cancer. Since ultrasonography is a performer dependent diagnostic modality, chapter $V$, shows how the "interexamination" agreement for ultrasonography of the whole breast was determined. The interexamination agreement of ultrasonography means the agreement between test results for the complete process of performing the ultrasonography examination and interpreting the dynamic scanning and the static images by the same person, in order to derive a probability of malignancy of an ultrasonographic breast lesion. One hundred and thirteen breasts in 58 patients underwent the ultrasonographic investigation by three independent sonographers. Statistical analysis showed a substantial interexamination agreement between the three sonographers, who had different backgrounds and levels of experience.

All palpable breast lesions from the study population of the larger study earlier described $(n=2020$, chapter IV), which underwent additional pte-operative diagnostic investigations, were further analysed $(n=258$, chapter VI). Pre-operatively obtained fine needle aspiration cytology results $(n=241)$ and histological core needle biopsy results $(n=70)$ were compared to the histological results after surgical excision $(n=190) \mathrm{and} / \mathrm{or}$ 12 months of follow-up, to determine the necessity of these pre-operative diagnostic modalities. Fine needle aspiration cytology was non-conclusive in $17 \%$ of cases. When combined with physical examination and imaging (e.g., triple diagnostic test), there were no non-conclusive test tesults.

The rate of non-conclusiveness of the histological core needle biopsy was $6 \%$. Statistical analysis in this study could not provicle evidence for omitting fine needle aspiration cytology or histological core needle biopsy out of the diagnostic route. Fithermore we could not find patient or imaging oriented parameters that could exclude fine needle aspiration cytology in favour of the histological core needle biopsy in the first instance. Further research is necessary to determine performance or cost-effective reasons for omitting either fine needle aspiration cytology or histological core needle biopsy.

In chapter VII we were able to determine the best guidance for the histological core needle biopsy of a palpable breast lesion. Two hundred and sixty-seven palpable breast lesions underwent a histological core needle biopsy (209 by imaging guidance, 58 by palpation guidance). Although our impression was that the main selection was due to logistical teasons, the difference in tumour size between the two groups suggests at least one other selection criteria. Nevertheless umage-guided histological core needle biopsies were significantly more accurate than palpation-guided biopsies. Size seems to lure physicians, motivating them to perform a histological core needle biopsy guided by palpation. 
From the different studies described in this thesis we might consider the dingnosis of breast cancer as a complex rualtidisciplinary matter. It needs dedicated physicians to continually optimise the diagnostic route for the individual patient. 


\section{Samenvatting Dankwoord Curriculum vitae}




\section{SAMENVATTING}

Het mammacarcinoom (borstkanker, mamma = borst) is de meest voorkomende vorm wan kanker bij vrouwen in Nederland. Jaalijks wordt bij ruim 10.000 viouwen een mammacatcinoom vastgesteld. Eén op de 9 vrouwen krijgt op een bepaald moment gedurende haat leven een mammacarcinoom. Behalve het levensbedreigende aspect, heeft het mammacarcinoom een sterke emotionele impact op de vrouw, mede door de soms mutillerende chirurgische ingrepen die nodig zijn om de ziekte te behandelen.

Huisartsen en specialisten moeten een mammalaesie (knobbeltie in de borsc) en andere mammagerelateerde klachten evenals een verhoogd risico op een mammacarcinoom onderkennen en de juiste diagnostiek (laten) vitvoeren. De gangbare onderzoeken van de mammae zijn het lichamelijk onderzoek en beeldvorming. De radioloog, verantwootdelijk voor deze beeldworming, heeft meerdere technieken ter beschilking om mammaweefsel af te beelden. Algemeen toegepast worden het röntgenonderzoek (mammogram, ook wel bekend wan het bevolkingsonderzoek) en het echografisch onderzoek dat gebruik maakt van gehuidsgolven.

Voor een defintieve diagnose is naast lichamelijk onderzoek en beeldvorming ook celonderzoek en/of weetselonderzoek nodig van een afwijking in de mamma. De chirurg; radioloog of patholoog verkrigt met een dunne (21 Gauge $\approx 0.8 \mathrm{~mm}$ ) of dikke (14 Gauge $\approx 2.0 \mathrm{~mm}$ ) naald een representatief monster van een afwijkend gebied wit de mamma. De patholoog beoordeelt dit na kleuringen onder de microscoop. leder diagnostisch onderzoek heeft zijn fout-positieve (het onderzoek zegt dat de patient de ziekte heeft, maar in werkelijkheid is de persoon gezond) en fout-negatieve (het onderzoek zegt dat de persoon niet ziek is, maar in werkelijkheid heeft de patient toch de ziekte) vitslagen. Hierdoor komt het voor dat tot het moment van chirurgische behandeling van cen verdachte afwijking in de mamma het niet duidelijk is of het een goedarardige dan wel kwaadaardige laesie betreft. De chirurg heeft dan tot taak met cen operatieve ingreep weefsel te verkrijgen en dit door de patholoog te laten onderzoeken om een definitieve uitslag te krijgen. In hoofdstuk II van dit proefschrift wordt aangetoond dat een juiste (kwadaardig of goedaardig) pre-operatieve diagnose ook een betere behandeling tot gevolg heeft. In een groep van 400 niet-palpabele (niet te voelen) mammalaesies (208 kwaadaardig), bleken de 77 laesies waarwan de kwandaardige diagnose pre-operatief bij de chirurg bekend was drie keer zo vaak bij de eerste operatieve ingreep volledig verwijderd te zijn en was minder waak een borstamputatie noodzakelijk.

Pre-operatief een juiste diagnose stellen, betekent ook de precieze afmetingen van de tumor bepalen. De grootte van en mammacarcinoom bepaalt mede de prognose (verloop van de ziekte) en heeft consequenties voor de behandeling. In hoofdstuk III wordt onderzochr hoe de grootte van een mammacarcinoom pre-operatief het meest nauwkeurig bepaald kan worden: met het lichamelijk onderzoek, het mammogram of met de echografie. De maximale afmeting van 105 kwaadaardige mamma tumoren zijn hiervoor gemeten bij zowel het lichamelijk onderzoek, het mammogram als het echografisch onderzoek. Deze resultaten werden vergeleken met de afmetingen die de patholoog heeft bepaald nadat de tumot chirurgisch was verwijderd. De echografische mecingen bleken daarbij significant beter overeen te komen mer de bevindingen bij pathologisch anatomisch onderzoek, dan de metingen bij lichamelijk onderzock en 
mammografic. Algemeen kan gezegd worden dat de werkelijk maximale diameter van een mammatumor gelijk is aan de echografische diameter $+3 \mathrm{~mm}$.

In hoofdstuk IV zijn de resultaten gepresenteerd van een prospectief onderzoek uitgevoerd in het academisch ziekenhuis Mastricht tussen oktober 1999 en augustus 2000. Het doel van deze sudie was het bepalen wan de diagnostische waarde wan het echografisch onderzoek van de mammae als aanvulling op het lichamelijk en het matnmografisch onderzoek bij het vaststellen van het mammacarcinoom. In 3835 mammae vat 2020 openvolgende poliklinisch patienten die door huisarts of specialist (ook wia het nationaal bewolkingsonderzoek) doorverwezen werden voor diagnostisch beeldvormend onderzoek, werd lichamelijk onderzoek van de mammae, mammografie en echogtafie uitgevoerd. Alle onderzoeken werden gescoord op een 5-punts schaal met oplopende graad van verdenking op een mammacarcinoom: 1 = normaal, 2 = goedaardig, $3=$ onzeker goedaardig, $4=$ verdacht kwadaardig en $5=$ zeker kwaadaardig. De pathologisch anatomische uitslagen van puncties, biopsieën en chinurgische verwijleringen gedurende de opvolgende 12 maanden na het initiële onderzoek werden gebruikt als referentie voor de aanwezigheid van een mammacarcinoom. In totaal werd $₫ 29$ keer borstkanker gevonden in 127 patiënten $(127 / 2020=6,3 \%$ prevalentie (vootkomen)).

Echografisch onderzoek detecteerde 8 extra borstkankers en zorgde voor een correcte aanpassing van 332 verdachte diagnosen bij lichamelijk onderzoek en mammografie in een negatieve (geen mammacarcinoom) einddiagnose. Statistisch onderzoek toonde aan dat meer mamma-afwijkingen juist werden gekenmerkt (goedaardig dan wel kwaadaardig), wanneer resultaten van de echografie werden toegevoegd aan die van het lichamelijk onderzoek en de mammografie. Dit effect was het duidelijkst bij patiënten die verwezen werden met een palpabele afwijking of met een afwijking die werd vastgesteld op het screeningsmammogram van het nationale bevolkingsonderzoek.

Uit de hoofdstukken III en IV is gebleken dat het echografisch onderzaek een positieve invloed kan hebben bij de diagnostiek van het mammacarcinoom. Aangezien het echografisch onderzoek een onderzoeker afhankelijke testmodaliteit is, werd in hoofdstuk V de "inter-onderzoek" overeenkomst van het echografisch onderzoek wan de mamma bepaald. Met de "inter-ondetzoek" overeenkomst wordt de overeenkomst dan wel variatie bedoeld die ontstaat in testuitslagen als twee of meer onderzoekers onafhankelijk van elkaar dezelfde mamma echografisch onderzoeken. Bij het echografisch onderzock gat het dan om de combinate van zowel het uitvoeten van het echografisch onderzoek, als het interpreteren van de verkregen beelden om zo witeindelijk te komen tot een warschijnlijkheidsoordeel over het al dan niet kwaadaardig zijn van een al dan niet aatnwezige afwijking. Bij 58 patiènten met een indicatie voor mammogtafie werden 113 mammae door drie onafhankelijke echografisten onderzocht. Ondanks het feit dat de ervaring wan deze drie echografisten nogal verschilden, was de "inter-onderzoek" overeenkomst aanzienlijk en de variatie geting.

Uit de onderzoeksgroep van de eerder beschreven grote studie (2020 onderzochte mensen, (hoofdstulk IV) zijn van alle palpabele afwijkingen $(n=258$ ) het pre-operatief verkregen celonderzoek- $(\mathrm{n}=241)$ en/of weefselonderzoek- $(\mathrm{n}=70)$ resultaten vergeleken met het weefselonderzoek van het operatief verkregen weefsel $(n=190)$ en/of 12 maanden opvolgen van de patiënt, teneinde een indruk te krijgen van de noodzaak van 
deze voor de patiënt belastende pre-operatieve diagnostiek (hoofdstuk VI). Het celonderzoek was inadequat (er kon geen uitslag worden gegeven) in $17 \%$ van de gevallen. In combinatie met lichamelijk onderzoek en beeldvorming (triple diagnostiek) waten er geen inadequate testresultaten.

Het aantal inadequate uitslagen van het weefselonderzoek was $3(6 \%)$. Statistisch onderzoek van de groepen met of zonder celonderzoek dan wel weefselonderzoek toonde geen verschil in correct vaststellen van de ziekte borstkanker. Het was ook niet mogelijk factoren uit anamnese, lichamelijk onderzoek of beeldvorming te bepalen die bij voorbaat konden voorspellen dat het celonderzoek achterwege gelaten kon worden en direct het weefselonderzoek uitgevoerd moest worden. Nader onderzoek is nodig om te bepalen of het celonderzoek, dan wel het weefselonderzoek achterwege gelaten kan worden uit diagnostische en kosteneffectiviteitoverwegingen.

In hoofdstuk VII wordt aangetoond dat het verkrijgen van weefsel ten behoeve van pre-operatief histologisch onderzoek het beste onder beeldgeleide (röntgen dan wel echografie) verkregen kan worden. Tweehonderdzevenenzestig palpabele mammalaesies ondergingen een histologisch dikke naald biopt ( 209 beeldgeleid en 58 zonder hulp van beeldvorming). De keuze van de methode (wel of niet beeldgeleid) wetd met name bepaald door de logistiek (wachttijden). De mammalaesies die zonder beeldgeleiding waren gebiopteerd hadden gemiddeld een grotere diameter. Echter ook bij die grotere tumoren was de onder beeldgeleide uitgevoerde dikke naaldbiopsie nauwkeuriger dan het blinde biopt. Hieruit kan geconcludeerd worden dat een specialist zich niet moet laten verleiden tot het pre-operatief verkrigen van weefsel van een mammalaesie zonder gebruik te maken van beeldvorming.

Mede uit de resultaten van de verschillende studies die beschreven worden in dit proefschrift blijkt dat de diagnostiek van het mammacarcinoom een complexe multidisciplinaire aangelegenheid is die toegewijde artsen nodig heeft om voortdurend het optimale diagnostische traject voor de individuele patiënt te bepalen en uit te voeren. 


\section{DANKWOORD}

Ik zou iedereen persoonlijk moeten hebben bedankt op het juiste moment. Hopelijk heeft iedereen mijn dankbaarheid gemerkt op de specifieke momenten tijdens de samenwerking. Zonder hun hulp, steun, inzicht, beoordeling, medewetking en geduld zou dit proefschrift niet zijn afgerond.

Tot deze personen behoren: de patiënten, de promotoren, de co-promotor, de methodoloog/statisticus, de mede-onderzoekster, de epidemiologe, de assistentonderzoekers, de (mamma-)radiologen, de mammografie laboranten en technici, de (mamma-)chirurgen, de patholoog, en de PALGA medewerkers, de (wisselende) kamergenoten, de secretariaat-medewerkers van de afdelingen tadiologie en chirurgie, de engels correctoren, de overige collega's, vrienden, de paranimfen en mijn zussen en ouders.

Bedankt dat jullie er waten en zijn. 


\section{CURRICULUM VITAE}

Anna Maria Bosch is geboren op 14 jaruari 1970 in Pannerden, Gelderland. Ze doorliep het V.W.O. aan het Liemers College te Zevenaar (1982-1988). Na twee jaar gezondheidswetenschappen (1988-1989 Rijksuniversiteit Limburg (huidige Universiteit Maastricht) en 1989-1990 Nijmegen. (Katholieke Universiteit Nijmegen)), begon ze de artsenopleiding aan de Katholieke Universiteit te Nijmegen in 1990. In juli 1994 behaalde ze haar doctoral en in januari 1997 het artsexamen. Gedurende een jaat werkte ze als atts-coördinator van het traumatologie onderzoek in het Academisch Ziekenhuis Utrecht onder prof. Chr. van der Werken (huidige Universitair Medisch Centrum Utrecht). In 1998-1999 deed ze klinische ervaring in de algemene heelkunde op als AGNIO bij de afdeling algemene heelkunde in het Academisch Ziekenhuis Maastricht (prof. G. Kootstra). In oktober 1999 begon zij het promotieondetzoek. (MAMMOED-studie) bij de afdeling radiologie/chirurgie van het Academisch Ziekenhuis Maastricht dat leidde tot dit proefschrift. De promotie is voltooid in samenwerking met dr. G.L. Beets en dr. K. Flobbe en onder leiding van prof. dr. M.F. von Meyenfeldt en prof dr. J.M.A. wan Engelshoven. Vanaf juli 2001 is de afronding van de promotie uitgevoerd in combinatie met de opleiding tot algemeen chirurg in her. Academisch Ziekenhuis Maastricht (prof. M. Jacobs/dr. J.W. Greve) en het Máxima Medisch Centrum, locatie Eindhoven (dr. W.J. Praklken).

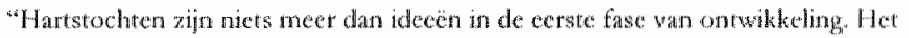
zijn kenmertien wan her jeugdige hast en slechas een dwats geloofi, dat xe bem

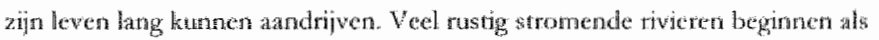

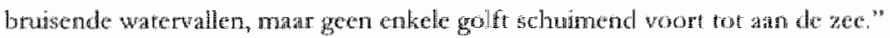

(M. 1.emonor) 
Life is terible and so is liwing roo.

Life is horroble if you know what life can do.

If grom want to be happy,

You have to be blind,

You won't see the bad things,

And life will be kind. 
